\title{
Macroalgae as a Source of Valuable Antimicrobial Compounds: Extraction and Applications
}

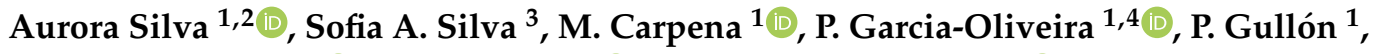 \\ M. Fátima Barroso ${ }^{2}\left(\mathbb{D}\right.$, M.A. Prieto ${ }^{1, * \mathbb{D}}$ and J. Simal-Gandara 1,*(D) \\ 1 Nutrition and Bromatology Group, Department of Analytical and Food Chemistry, Faculty of Food Science \\ and Technology, University of Vigo, Ourense Campus, E32004 Ourense, Spain; mass@isep.ipp.pt (A.S.); \\ maria.carpena.rodriguez@uvigo.es (M.C.); paula.garcia.oliveira@uvigo.es (P.G.-O.); \\ patrigullon@gmail.com (P.G.) \\ 2 REQUIMTE/LAQV, Instituto Superior de Engenharia do Porto, Instituto Politécnico do Porto, Rua Dr \\ António Bernardino de Almeida 431, 4200-072 Porto, Portugal; MFSBA@isep.ipp.pt \\ 3 Departamento de Química, Universidade de Aveiro, 3810-168 Aveiro, Portugal; sofia.silva96@gmail.com \\ 4 Centro de Investigação de Montanha (CIMO), Instituto Politécnico de Bragança, Campus de Santa Apolonia, \\ 5300-253 Bragança, Portugal \\ * Correspondence: mprieto@uvigo.es (M.A.P.); jsimal@uvigo.es (J.S.-G.)
}

Received: 2 August 2020; Accepted: 22 September 2020; Published: 25 September 2020

check for updates

\begin{abstract}
In the last few decades, attention on new natural antimicrobial compounds has arisen due to a change in consumer preferences and the increase in the number of resistant microorganisms. Macroalgae play a special role in the pursuit of new active molecules as they have been traditionally consumed and are known for their chemical and nutritional composition and their biological properties, including antimicrobial activity. Among the bioactive molecules of algae, proteins and peptides, polysaccharides, polyphenols, polyunsaturated fatty acids and pigments can be highlighted. However, for the complete obtaining and incorporation of these molecules, it is essential to achieve easy, profitable and sustainable recovery of these compounds. For this purpose, novel liquid-liquid and solid-liquid extraction techniques have been studied, such as supercritical, ultrasound, microwave, enzymatic, high pressure, accelerated solvent and intensity pulsed electric fields extraction techniques. Moreover, different applications have been proposed for these compounds, such as preservatives in the food or cosmetic industries, as antibiotics in the pharmaceutical industry, as antibiofilm, antifouling, coating in active packaging, prebiotics or in nanoparticles. This review presents the main antimicrobial potential of macroalgae, their specific bioactive compounds and novel green extraction technologies to efficiently extract them, with emphasis on the antibacterial and antifungal data and their applications.
\end{abstract}

Keywords: antimicrobial applications; antimicrobial compounds; bioactive compounds; macroalgae; novel technologies

\section{Introduction}

Approximately $70 \%$ of the Earth's surface is covered by marine waterand thus, the marine world is home to a huge diversity of species. Several organisms have been proposed as sources of known beneficial compounds and other new molecules with biological potential [1,2]. Nowadays, there are more than 200,000 eukaryotic marine species validated, among which, algae contribute nearly 44,000 described species [3]. Among algae, macroalgae (also called seaweed) constitute a new source of compounds, as they have been used traditionally for nutritional or medicinal purposes [4]. They are defined as marine macroscopic eukaryote photosynthetic organisms. Among them, plenty of divisions 
can be established depending on the chosen criteria, however the most common classification divides macroalgae in three groups depending on their pigments: green (Chlorophyceae), red (Rhodophyceae) and brown algae (Ochrophyta) [5,6].

More recently, functional products and especially, natural functional ingredients have enjoyed a boost in consumer demand. These products are usually preferred by the client over synthetic ingredients; a trend that is growing not only in the food industry but also in other sectors. In this context, macroalgae entail a source of valuable compounds for their nutritional and chemical composition [7]. Algae's nutritional profile usually consists of minerals (7-36\%), lipids (1-5\%), polysaccharides (15-76\%) and proteins (5-47\%) [3,8,9]. Concretely, algae polysaccharides (namely, agar, alginate or carrageenans, among others) have been widely studied for their food applications as thickener, stabilizer or emulsifier agents $[10,11]$. On the other hand, even though macroalgae have a low lipid content, they have a high proportion of poly-unsaturated fatty acids (PUFAs) and other lipid compounds with beneficial health properties [9,12]. Moreover, they also show an elevated content of micro-nutrients such as vitamins and other secondary metabolites, usually antioxidants, such as polyphenols or pigments [10]. In sight of the variety of active molecules reported in algae, their extracts have been submitted to different bioactivity tests showing plenty of biological properties, such as: anti-inflammatory, antioxidant, antimicrobial, antidiabetic, anticancer, neuroprotective and photoprotective, among others [13-15]. Regarding all these aspects, macroalgae may be considered as a source of active molecules with biological properties and with a huge potential for application in food, cosmetic and pharmacological industries, not only because of their composition but also for their diversity and the availability of resources [16-18].

During the last decades, two main trends have stimulated interest in new natural antimicrobial compounds. First, natural ingredients with preservative properties have experienced an increasing demand, in replacement of the use of synthetic ingredients, to prevent microbial contamination as they are safer, ecofriendly, they possess a wide spectra of actions and they avoid some of the side-effects associated with synthetic antimicrobials $[19,20]$. Second, in recent decades, an increase in the number of pathogens (bacteria and fungi) resistant to antimicrobial drugs has occurred. This issue is considered now as a public health problem since traditional antibiotics and antifungals have lost efficacy [21].

In Figure 1, a schematic summary of the main resistance acquisition pathways (fundamentally by mutation or by acquiring mobile genetic elements with resistance genes) [22] and the main mechanisms of resistance to antibiotics is shown. In this context, marine macroalgae have shown antimicrobial potential and in some cases, a synergistic effect with conventional antimicrobial agents against drug-resistant pathogens [1]. Thus, this association can be applied to the pharmaceutical sector and also to the food industry, where consumer resistance is also a reality and food-spoilage-microorganisms control is a must in the food chain supply [23]. Nevertheless, the search for antimicrobial compounds in algae is not a recent idea. A study carried out in 1974, screened 151 species of British marine algae against different microorganisms in order to find new alternatives for the production of antibiotics [24]. However, considering the reviewed bibliography, the vast majority of the studies have focused on the general screening of the antimicrobial properties of algae extracts, whereas information about the purified molecule's specific mechanism of action is quite scarce, with polyphenols being the molecules most studied [20,23]. Moreover, research has mostly focused on clinical bacteria, not on food related pathogens [25]. 




Figure 1. Summary of the resistance acquisition pathways: Mutation and mobile genetic elements: By transduction, transformation or conjugation. Schema of the six main mechanisms of antibiotics resistance. Modified from [1,26,27].

Given the actual interest in identifying antimicrobial compounds from algae, it is essential to achieve profitable and sustainable recovery of these compounds, in an easy and fast process [28]. Sometimes these compounds could be synthesized chemically, however, regarding the availability of algae, their recovery using green extraction technologies is an economic and environmentally friendly alternative that also avoids the use of dangerous chemical compounds. The extraction of bioactive compounds has always been a fundamental step in recovering these molecules from vegetal matrixes. New techniques have been developed in order to reduce extraction time, energy consumption, quantity of solvent, environmental implications, economical cost and waste productions while increasing the extraction efficiency and the quality of the obtained extract [29].

The most common classic technique applied to extract bioactive compounds from macroalgae is the maceration at different temperatures, followed by Soxhlet. It is also notable that the most frequently chosen solvents are methanol and ethanol even though other solvents with different characteristics are also successfully used. In this regard, Table 1 presents a compilation of the last 10 years of literature, refereeing studied algae species, the focus on the extraction conditions and highlighting the major outcomes achieved. Nowadays, novel liquid-liquid and solid-liquid extraction techniques are currently more applied, including: supercritical, ultrasound, microwave, enzymatic, high pressure, accelerated solvent and intensity pulsed electric fields extraction techniques [30]. In this regard, the combination of green technologies and safe environmental solvents is desirable to obtain efficient extraction of biocompounds, preserving their biological properties and opening the door to their implementation in the food, cosmetic and pharmaceutical industries. Once the target compounds are efficiently well extracted, the resultant extracts can be incorporated into different products. In general, the most common application would be the incorporation into food matrixes as preservatives [25], to cosmetic products [31] or as antibiotics with a synergistic effect on the pharmaceutical industry [1]. Moreover, other applications have been investigated such as antibiofilm [32], antifouling [33], coating in active packaging [34] or as prebiotics [11], among others. Therefore, the aim of this article is to review the main compounds responsible for the antimicrobial activity of algae, the novel extraction techniques for obtaining them and their applications. 
Table 1. Antimicrobial activity of algae crude extracts obtained using classic extraction technologies from 2010 to 2020.

\begin{tabular}{|c|c|c|c|c|}
\hline Alga Species & Conditions & Bacteria Tested & Main Outcomes & Ref. \\
\hline L. brandenii-(India) & $\begin{array}{c}\mathrm{HAE}, \mathrm{MeOH}: \\
\mathrm{CHCl}_{3}(6: 4), 35^{\circ} \mathrm{C}, \\
120 \mathrm{rpm}, 7 \text { days }\end{array}$ & $\begin{array}{c}\text { S. aureus/B. } \\
\text { subtilis/M.luteus/R. } \\
\text { rhodochrous/E. } \\
\text { coli/P.aeruginosa/Vibrio } \\
\text { cholerae/Salmonella } \\
\text { typhi/Streptococcus } \\
\text { pneumoniae }\end{array}$ & $\begin{array}{l}\text { All organisms were } \\
\text { inhibited. High } \\
\text { activity against } B . \\
\text { subtilis whereas it } \\
\text { was moderate } \\
\text { against } E \text {. coli }\end{array}$ & [35] \\
\hline G. ornata-(Brazil) & $\begin{array}{c}\mathrm{HAE}, \mathrm{H}_{2} \mathrm{O}, 25^{\circ} \mathrm{C} \\
24 \mathrm{~h}\end{array}$ & $\begin{array}{c}\text { B. subtilis/S. aureus/E. } \\
\text { aerogens/E. coli/P. } \\
\text { aeruginosa/S. choleraesuis/S. } \\
\text { typhi }\end{array}$ & $\begin{array}{l}\text { Only exhibits } \\
\text { inhibition to E. coli }\end{array}$ & [36] \\
\hline C. rubrum-(Chile) & $\begin{array}{l}\text { HAE }(3 x), 96 \% \\
\text { EtOH, } 24 \text { h. }\end{array}$ & S. parasitica/Y. ruckeri & $\begin{array}{l}\text { Antibacterial and } \\
\text { antifungal activities } \\
\text { against fish } \\
\text { pathogens }\end{array}$ & [37] \\
\hline G. changii-(Malaysia) & $\begin{array}{c}\text { Solid liquid } \\
\text { extraction, } \mathrm{MeOH}, \\
4 \text { days. }\end{array}$ & P. aeruginosa & $\begin{array}{l}\text { Minimal inhibitory } \\
\text { concentration (MIC) } \\
6.25 \mathrm{mg} / \mathrm{mL}\end{array}$ & [38] \\
\hline $\begin{array}{c}\text { P. capillacea/O. } \\
\text { obtusiloba-(Brazil) }\end{array}$ & $\begin{array}{l}\text { Solid liquid } \\
\text { extraction, cold } \mathrm{Hx} \\
\text { and } 70 \% \mathrm{EtOH} \text {. }\end{array}$ & $\begin{array}{c}\text { E. coli/S. aureus/Salmonella } \\
\text { sp./V. harveyi }\end{array}$ & $\begin{array}{l}\text { No antimicrobial } \\
\text { activity. }\end{array}$ & [39] \\
\hline $\begin{array}{c}P . \\
\text { gymnospora-(Brazil) }\end{array}$ & $\begin{array}{c}\text { Percolation with } \\
\mathrm{MeOH}\end{array}$ & S. aureus & MIC $500 \mu \mathrm{g} / \mathrm{mL}$ & [40] \\
\hline $\begin{array}{c}\text { S. latifolium/S. } \\
\text { platycarpum/C. } \\
\text { socialis-(Arabian } \\
\text { Gulf) }\end{array}$ & $\begin{array}{l}\text { HAE extraction, } \\
\mathrm{MeOH} \text { and AcO } 25 \\
{ }^{\circ} \mathrm{C}, 150 \mathrm{rpm}, 7 \text { days }\end{array}$ & $\begin{array}{c}\text { S. aureus/S. } \\
\text { xylosus/MRSA/E. faecalis/B. } \\
\text { subtilis/E. coli/P. } \\
\text { aeruginosa/Salmonella sp./K. } \\
\text { pneumoniae/C. albicans }\end{array}$ & $\begin{array}{l}\text { Higher activity } \\
\text { against Gram } \\
\text { positive bacteria than } \\
\text { Gram negative }\end{array}$ & [41] \\
\hline $\begin{array}{l}\text { L. japonica-(Korea, } \\
\text { Japan, China) }\end{array}$ & $\begin{array}{c}\mathrm{HAE}(\mathrm{x} 3), \mathrm{EtOH}, 25 \\
{ }^{\circ} \mathrm{C}, 1 \text { day. }\end{array}$ & $\begin{array}{c}\text { S. mutans/S. sobrinus/A. } \\
\text { naeslundii/A. } \\
\text { odontolyticus/A. } \\
\text { actinomycetemcomitas/F. } \\
\text { nucleatum/P.gingivalis }\end{array}$ & $\begin{array}{l}\text { Inhibitory activity } \\
\text { against all } \\
\text { microorganisms }\end{array}$ & [42] \\
\hline $\begin{array}{l}\text { D. membranacea- } \\
\text { (Mediterranean Sea) }\end{array}$ & $\begin{array}{l}\text { Column extraction, } \\
\text { EtOH, AcO and } \\
\mathrm{MeOH} / \mathrm{DCM}\end{array}$ & $\begin{array}{l}\text { S. aureus/S. agalactiae/B. } \\
\text { subtilis/E. faecium/E. } \\
\text { faecalis/E. coli/C. albicans }\end{array}$ & $\begin{array}{c}\text { EtOH and AcO } \\
\text { showed higher } \\
\text { antimicrobial activity }\end{array}$ & {$[43]$} \\
\hline $\begin{array}{c}S . \\
\text { oligocystum-(Persian } \\
\text { Gulf) }\end{array}$ & $\begin{array}{l}\mathrm{HAE} \text {, hot and cold } \\
\mathrm{H}_{2} \mathrm{O} \text { and glycerin }\end{array}$ & $\begin{array}{c}\text { S. aureus/S. epidermidis/P. } \\
\text { aeruginosa/E. coli }\end{array}$ & $\begin{array}{c}\text { Hot water extract } \\
\text { exhibited activity } \\
\text { against } S \text {. aureus, } S \text {. } \\
\text { epidermidis, and } P \text {. } \\
\text { aeruginosa }\end{array}$ & [44] \\
\hline $\begin{array}{l}\text { C. myrica/C. trinodis/P. } \\
\text { gymnospora/S. } \\
\text { dentifolium/S. hystrix/A. } \\
\text { fragilis/C. racemosa/C. } \\
\text { fragile-(Red sea) }\end{array}$ & $\begin{array}{l}\mathrm{HAE}, \mathrm{MeOH}, 25 \\
{ }^{\circ} \mathrm{C}, 50 \mathrm{rpm}, 7 \text { days. }\end{array}$ & $\begin{array}{c}\text { E. coli/S. aureus/E. } \\
\text { faecalis/Salmonella } \mathrm{sp} . / B . \\
\text { cereus/P. aeruginosa. }\end{array}$ & $\begin{array}{l}\text { MeOH extracts } P \text {. } \\
\text { gymnospora and } C \text {. } \\
\text { fragile showed the } \\
\text { highest activities }\end{array}$ & [45] \\
\hline $\begin{array}{c}\text { S. polycystum/P. } \\
\text { australis-(Malasya) }\end{array}$ & $\begin{array}{l}\text { HAE, Hx, DCM, } \\
\text { MeOH, } 72 \text { h }\end{array}$ & $\begin{array}{c}\text { S. aureus/B. cereus/E. coli/E. } \\
\text { coli/P. aeruginosa }\end{array}$ & $\begin{array}{c}\text { S. polycystum extracts } \\
\text { exhibited higher } \\
\text { bacteriostatic activity } \\
\text { Moderate }\end{array}$ & [46] \\
\hline $\begin{array}{l}\text { Gracilaria } \\
\text { sp.-(Malaysia } \\
\text { farmed algae) }\end{array}$ & $\mathrm{HAE}, \mathrm{MeOH}, 48 \mathrm{~h}$ & $\begin{array}{l}\text { B. subtilis/S. aureus/S. } \\
\text { epidermidis/E. coli/V. } \\
\text { cholera/E. cloacae. }\end{array}$ & $\begin{array}{c}\text { antibacterial activity } \\
\text { but } S \text {. aureus, } S \\
\text { epidermidis, E. cloacae } \\
\text { were not inhibited }\end{array}$ & [47] \\
\hline
\end{tabular}


Table 1. Cont.

\begin{tabular}{|c|c|c|c|c|}
\hline Alga Species & Conditions & Bacteria Tested & Main Outcomes & Ref. \\
\hline $\begin{array}{c}\text { P. antillarum/P. } \\
\text { boergesenii/U. } \\
\text { flexuosa-(Persian } \\
\text { Gulf) }\end{array}$ & $\begin{array}{l}\text { HAE, EtOAc, } \\
\text { MeOH; } 48 \text { h }\end{array}$ & $\begin{array}{c}\text { B. subtilis/B. pumulis/E. } \\
\text { faecalis/S. aureus/S. } \\
\text { epidermidis/E. coli/K. } \\
\text { pneumoniae/P. aeruginosa/A. } \\
\text { niger/C. albicans/S. cerevisiae }\end{array}$ & $\begin{array}{l}\text { A. niger, } P \text {. aeruginosa } \\
\text { were not inhibited. } P \text {. } \\
\text { antillarum extracts do } \\
\text { not have effect in } K \text {. } \\
\text { pneumoniae }\end{array}$ & [48] \\
\hline $\begin{array}{c}\text { U. lactuca/U. } \\
\text { intestinales/C. } \\
\text { vagabunda-(Black } \\
\text { sea) }\end{array}$ & $\mathrm{HAE}, \mathrm{EtOH} 70 \%$ & S. aureus/E. coli & $\begin{array}{l}\text { Antibacterial activity } \\
\text { was higher in E. coli }\end{array}$ & [49] \\
\hline U. rigida-(Turkey) & $\begin{array}{l}\text { HAE, DCM; then } \\
\text { DCM/MeOH }\end{array}$ & $\begin{array}{l}\text { S. agalactiae./S. aureus./E. } \\
\text { faecalis/Micrococcus sp./V. } \\
\text { tapetis/V. anguillarum/V. } \\
\text { alginolyticus E. coli/P. } \\
\text { cepacia/P. fluorescens/P. } \\
\text { aeruginosa/A. salmonicida/A. } \\
\text { hydrophila/S. typhimurium }\end{array}$ & $\begin{array}{l}\text { No significant } \\
\text { variation with } \\
\text { seasons. The most } \\
\text { sensitive bacteria } \\
\text { were } \text { A. salmonicida, } \\
\text { S. typhimurium, } S \text {. } \\
\text { agalactiae, A. } \\
\text { hydrophila, } P \text {. cepacia, } \\
\text { S. aureus and E. } \\
\text { faecalis }\end{array}$ & [50] \\
\hline G. doryphora-(Egypt) & $\begin{array}{l}\text { HAE, MeOH, } \\
\text { EtOH, EtOAc, } 72 \text { h, } \\
150 \text { rpm. }\end{array}$ & $\begin{array}{c}\text { B. subtilis/E. } \\
\text { faecalis/S. aureus/E. coli/P. } \\
\text { aeruginosa/C. albicans }\end{array}$ & $\begin{array}{l}\text { Inhibitory effects } \\
\text { except against } E \text {. coli }\end{array}$ & [51] \\
\hline $\begin{array}{c}\text { E. prolifera/U. } \\
\text { reticulata/C. myrica/P. } \\
\text { pavonica/T. triquetra/S. } \\
\text { portieriatum/G. } \\
\text { multipartita-(Saudi } \\
\text { Arabia) }\end{array}$ & $\begin{array}{l}\text { HAE, PeEt, DEt, } \\
\text { EtOAc, } \mathrm{MeOH}, 30 \\
{ }^{\circ} \mathrm{C}, 120 \mathrm{rpm}, 24 \mathrm{~h}\end{array}$ & $\begin{array}{c}\text { B. subtilis/MRSA/S aureus/E. } \\
\text { coli/K. pneumoniae/P. } \\
\text { aeruginosa }\end{array}$ & $\begin{array}{l}\text { P. pavonica and } T \text {. } \\
\text { triquetra extracts } \\
\text { showed better } \\
\text { activity. In some } \\
\text { cases, inhibitory } \\
\text { effects changed with } \\
\text { seasons }\end{array}$ & [52] \\
\hline $\begin{array}{c}\text { G. multipartita/U. } \\
\text { reticulata/S. } \\
\text { marginatum-(Turkey) }\end{array}$ & $\begin{array}{l}\mathrm{HAE}, \mathrm{Hx}, \mathrm{DCM}, \\
\mathrm{MeOH}, 72 \mathrm{~h}\end{array}$ & $\begin{array}{c}\text { B. subtilis/MRSA/S. aureus/E. } \\
\text { coli/K. pneumoniae/P. } \\
\text { aeruginosa }\end{array}$ & $\begin{array}{l}\text { B. subtilis, MRSA, } \\
\text { and E. coli were } \\
\text { susceptible }\end{array}$ & [53] \\
\hline $\begin{array}{c}\text { L. obtusa/C. } \\
\text { elongatum/C. } \\
\text { multifida-(Adriact } \\
\text { sea) }\end{array}$ & $\begin{array}{c}\text { Soxhlet extraction, } \\
\text { AcO }\end{array}$ & $\begin{array}{c}\text { B. mycoides/B. } \\
\text { subtilis/S. aureus/E. coli/K. } \\
\text { pneumoniae/A. flavus/A. } \\
\text { fumigatus/C. albicans/P. } \\
\text { verrucosum }\end{array}$ & $\begin{array}{l}\text { All the tested extracts } \\
\text { showed } \\
\text { antimicrobial activity }\end{array}$ & [54] \\
\hline $\begin{array}{c}\text { C. iyengarii/S. } \\
\text { asperum/S. } \\
\text { marginatum/C. indica/S. } \\
\text { variegatum/S. } \\
\text { swartzii/S. } \\
\text { tenerrimum/S. } \\
\text { ilicifolium/I. stellata/S. } \\
\text { robusta/H. tuna/R. } \\
\text { implexum/D. dichotoma } \\
\text { var. intricata/D. } \\
\text { indica/M. afaghusainii/J. } \\
\text { laminarioides-(Pakistan) }\end{array}$ & $\begin{array}{l}\mathrm{HAE}, \mathrm{EtOH}, 1 \\
\text { week }\end{array}$ & $\begin{array}{c}\text { B. subtilis/S. aureus/E. coli/S. } \\
\text { typhi/P. aeruginosa/R. } \\
\text { solani/Macrophomina } \\
\text { phaseolina/F. solani/F. } \\
\text { oxysporum }\end{array}$ & $\begin{array}{l}\text { Brown species have } \\
\text { shown more } \\
\text { potential than red } \\
\text { algal species. } \\
\text { The highest } \\
\text { antibacterial activity } \\
\text { was found in EtOH } \\
\text { extract of } D \text {. } \\
\text { dichotoma var intricata } \\
\text { and } D \text {. indica against } \\
\text { S. typhimurium }\end{array}$ & [55] \\
\hline $\begin{array}{l}\text { C. linum/C. rupestris/G. } \\
\text { dura/G. gracilis/G. } \\
\text { longissima/U. } \\
\text { prolifera-(Italy) }\end{array}$ & $\begin{array}{c}\text { Soxhlet extraction, } \\
\mathrm{CHCl}_{3} / \mathrm{MeOH}, 60 \\
{ }^{\circ} \mathrm{C}, 24 \mathrm{~h}\end{array}$ & $\begin{array}{c}V . \text { ordalii/ } V \text {. salmonicida } V . \\
\text { alginolyticus/V. splendidus/V. } \\
\text { harveyi/V. vulnificus }\end{array}$ & $\begin{array}{c}\text { Different } \\
\text { susceptibilities to } \\
\text { algal extracts were } \\
\text { detected. G. } \\
\text { longissima was the } \\
\text { most effective }\end{array}$ & [56] \\
\hline $\begin{array}{c}\text { C. } \\
\text { rupestris—(Mediterranean } \\
\text { Sea) }\end{array}$ & $\begin{array}{l}\mathrm{HAE}, \mathrm{MeOH} \\
\mathrm{CHCl}_{3}, \mathrm{H}_{2} \mathrm{O}\end{array}$ & $\begin{array}{l}\text { Enterococcus sp./S. } \\
\text { agalactiae/V. cholerae }\end{array}$ & $\begin{array}{l}\text { Results showed } \\
\text { seasonal variety }\end{array}$ & [57] \\
\hline
\end{tabular}


Table 1. Cont.

\begin{tabular}{|c|c|c|c|c|}
\hline Alga Species & Conditions & Bacteria Tested & Main Outcomes & Ref. \\
\hline $\begin{array}{c}\text { G. longissima- } \\
\text { (Mediterranean Sea) }\end{array}$ & $\begin{array}{c}\text { Soxhlet extraction, } \\
\mathrm{CHCl}_{3} / \mathrm{MeOH}(2: 1), \\
60^{\circ} \mathrm{C}, 24 \mathrm{~h}\end{array}$ & $\begin{array}{l}\text { P. aeruginosa/Enterococcus } \\
\text { sp./S. agalactiae/ } V . \\
\text { salmonicida/V. fluvialis/V. } \\
\text { vulnificus/V. cholerae/V. } \\
\text { alginolyticus/C. albicans/C. } \\
\text { famata/C. glabrata }\end{array}$ & $\begin{array}{c}\text { Moderate } \\
\text { antimicrobial effect } \\
\text { except on } V \text {. } \\
\text { salmonicida and } \\
\text { fungal species }\end{array}$ & [58] \\
\hline $\begin{array}{l}\text { C. antemmina/C. } \\
\text { peltata/C. } \\
\text { scalpelliformis/D. } \\
\text { dichotoma/S. } \\
\text { marginatum/A. } \\
\text { specifera/G. } \\
\text { lithophilia/G. } \\
\text { corticata-(India) }\end{array}$ & $\mathrm{HAE}, \mathrm{MeOH}$ & $\begin{array}{c}\text { E. coli/P. } \\
\text { aeruginosa/S. aureus/K. } \\
\text { pneumoniae }\end{array}$ & $\begin{array}{l}\text { G. lithophila presents } \\
\text { the most promising } \\
\text { results }\end{array}$ & [59] \\
\hline $\begin{array}{l}\text { J. rubens/C. elongata/P. } \\
\text { capillacea/U. fasciata/U. } \\
\text { lactuca/E. compressa/E. } \\
\text { linza/S. vulgare/C. } \\
\text { sinuosa-(Egypt) }\end{array}$ & $\begin{array}{l}\text { HAE, EtOH 70\%, } \\
\mathrm{MeOH} 70 \% \text { AcO } \\
70 \%, 150 \mathrm{rpm}, 72 \mathrm{~h}\end{array}$ & $\begin{array}{c}\text { B. subtilis/S. aureus/E. coli/S. } \\
\text { typhi/K. } \\
\text { pneumoniae/C. albicans. }\end{array}$ & $\begin{array}{l}\text { In all the tests, } \mathrm{AcO} \\
\text { showed the biggest } \\
\text { inhibition halos }\end{array}$ & [60] \\
\hline $\begin{array}{c}\text { D. flabellata/P. } \\
\text { concrescens/L. } \\
\text { johnstonii/G. } \\
\text { martinensis/U. } \\
\text { lactuca/C. } \\
\text { fragile-(Mexico) }\end{array}$ & HAE, AcO:MeOH & $\begin{array}{l}\text { E. coli/S. aureus/B. cereus/B. } \\
\text { subtilis/S. epidermidis }\end{array}$ & $\begin{array}{l}\text { L. johnstonii, } D \text {. } \\
\text { flabellata and } U \text {. } \\
\text { lactuca presented } \\
\text { activity against } \\
\text { pathogenic bacteria } \\
\text { tested }\end{array}$ & [61] \\
\hline $\begin{array}{l}\text { E. bicyclis-(South } \\
\text { Korea) }\end{array}$ & $\begin{array}{l}\mathrm{HAE}, \mathrm{MeOH}, 70 \\
{ }^{\circ} \mathrm{C}, 3 \mathrm{~h}\end{array}$ & $\begin{array}{c}\text { C. acnes/S. aureus/S. } \\
\text { epidermidis/P. aeruginosa }\end{array}$ & $\begin{array}{l}\text { Inhibitory effects } \\
\text { except against } P \text {. } \\
\text { aeruginosa }\end{array}$ & [62] \\
\hline $\begin{array}{l}\text { C. trinodis-(Persian } \\
\text { Gulf)-(Persian Gulf) }\end{array}$ & $\begin{array}{c}\text { HAE, } \\
\text { DEt:EtOH:Hx }\end{array}$ & $\begin{array}{c}\text { S. aureus/S. epidermidis/E. } \\
\text { coli/P. aeruginosa }\end{array}$ & $\begin{array}{l}\text { The best Inhibitory } \\
\text { effect was against } S \text {. } \\
\text { epidermidis was the } \\
\text { worst against } P \text {. } \\
\text { aeruginosa }\end{array}$ & [63] \\
\hline $\begin{array}{l}\text { C. glomerata,/E. linza/U. } \\
\text { rigida/C. barbata/P. } \\
\text { pavonica/C. ciliatum/C. } \\
\text { officinalis_(Black sea } \\
\text { Turkey) }\end{array}$ & HAE, 95\% EtOH & $\begin{array}{l}\text { S. aureus/B. cereus/A. niger/S } \\
\text { typhimurium/L. } \\
\text { monocytogenes/E. } \\
\text { coli/C. albicans/P. aeruginosa }\end{array}$ & $\begin{array}{c}\text { All alga extracts } \\
\text { present antimicrobial } \\
\text { activity }\end{array}$ & [64] \\
\hline $\begin{array}{l}\text { S. vulgare/C. hirsutus/R. } \\
\text { verruculosa-(Coast of } \\
\text { Algeria) }\end{array}$ & $\begin{array}{l}\text { Soxhlet extraction, } \\
\text { MeOH, MeOH: } \\
\mathrm{CHCl}_{3}, 6 \mathrm{~h}\end{array}$ & $\begin{array}{c}\text { B. cereus/S. aureus/M. } \\
\text { luteus/P. aeruginosa/E. coli/K. } \\
\text { pneumoniae/C. albicans }\end{array}$ & $\begin{array}{c}\text { Positive } \\
\text { antimicrobial results } \\
\text { against } S \text {. aureus and } \\
\text { B. cereus }\end{array}$ & [65] \\
\hline $\begin{array}{c}\text { Laurencia ssp. } \\
\text { (aldingensis/catarinensis/ } \\
\text { dendroidea/intricata/ } \\
\text { translucida)-(Brazil) }\end{array}$ & $\begin{array}{l}\mathrm{HAE}, \mathrm{Hx}, \mathrm{CHCl}_{3}, \\
\quad \mathrm{MeOH}, \mathrm{H}_{2} \mathrm{O}\end{array}$ & $\begin{array}{c}\text { C. albicans/C. parapsilosis/C. } \\
\text { neoformans }\end{array}$ & $\begin{array}{l}\text { L. aldingensis showed } \\
\text { the best antifungal } \\
\text { effects }\end{array}$ & [66] \\
\hline $\begin{array}{c}D . \\
\text { membranacea-(Tunisia) }\end{array}$ & $\begin{array}{c}\mathrm{HAE}, \mathrm{H}_{2} \mathrm{O}, \mathrm{CHCl}_{3} \\
\text { EtOAc }\end{array}$ & $\begin{array}{l}\text { S. aureus/S. epidermidis/L. } \\
\text { monocytogenes/M. luteus/E. } \\
\text { faecium/E. coli/P. } \\
\text { aeruginosa/S. } \\
\text { typhimurium/C. albicans/C. } \\
\text { kefyr/C. } \text { krusei/C. } \\
\text { dubliniensis/C. glabrata }\end{array}$ & $\begin{array}{l}\text { Inhibitory effects } \\
\text { against } M \text {. luteus, } \\
\text { S. aureus, S. } \\
\text { epidermidis, L. } \\
\text { monocytogenes, C. } \\
\text { krusei, C. dubliniensis } \\
\text { and C. kefyr } \\
\text { EtOA. and AcO }\end{array}$ & [67] \\
\hline $\begin{array}{l}\text { S. wightii/C. linum/P. } \\
\text { gymnospora-(India) }\end{array}$ & $\begin{array}{l}\text { HAE, } \mathrm{Hx}, \text { EtOAc, } \\
\text { AcO, } \mathrm{MeOH}\end{array}$ & $\begin{array}{c}\text { P. aeruginosa/S. typhi/E. } \\
\text { amylovora/E. aerogens/P. } \\
\text { vulgaris/K. pneumonia/E. } \\
\text { coli/MRSA/B. subtilis/E. } \\
\text { faecalis }\end{array}$ & $\begin{array}{l}\text { extracts were more } \\
\text { efficient, but no } \\
\text { inhibitory effects } \\
\text { were observed } \\
\text { against S. paratyphi } \\
\text { and K. pneumonia. }\end{array}$ & [68] \\
\hline
\end{tabular}


Table 1. Cont.

\begin{tabular}{|c|c|c|c|c|}
\hline Alga Species & Conditions & Bacteria Tested & Main Outcomes & Ref. \\
\hline $\begin{array}{c}\text { Fucus spp./P. } \\
\text { elongata/Rhodomela } \\
\text { confervoides/S. } \\
\text { latissima./C. rupestris/D. } \\
\text { contorta/F. } \\
\text { vesiculosus/C. } \\
\text { rubrum/M. stellatus/L. } \\
\text { digitata-(Germany) }\end{array}$ & HAE, DCM & $\begin{array}{c}\text { E. amylovora/E. coli/P. } \\
\text { aeruginosa/B. subtilis/S. } \\
\text { lentus }\end{array}$ & $\begin{array}{l}\text { The macroalgae } \\
\text { presented } \\
\text { antibacterial activity } \\
\text { against at least one of } \\
\text { the test strains }\end{array}$ & [69] \\
\hline $\begin{array}{l}\text { H. tuna/C. barbata/C. } \\
\text { bursa-(Montenegro) }\end{array}$ & $\begin{array}{c}\text { HAE, DCM:MeOH, } \\
48 \mathrm{~h}\end{array}$ & $\begin{array}{l}\text { E. coli/S. aureus/B. subtilis/E. } \\
\text { faecalis/C. albicans }\end{array}$ & $\begin{array}{c}\text { C. barbata } \\
\text { demonstrated as } \\
\text { having the best } \\
\text { antimicrobial activity } \\
\text { for S. aureus and } B \text {. } \\
\text { subtilis }\end{array}$ & [70] \\
\hline $\begin{array}{l}\text { G. corticata/G. } \\
\text { edulis-(India) }\end{array}$ & $\begin{array}{c}\text { HAE, DMSO, } 70 \% \\
\text { MeOH, } 130 \text { rpm, } 16 \\
\text { h }\end{array}$ & $\begin{array}{l}\text { E. coli/Photobacterium sp./P. } \\
\text { fluorescens/S. aureus/B. } \\
\text { subtilis }\end{array}$ & $\begin{array}{c}\mathrm{MeOH} \text { and DMSO } \\
\text { extracts inhibited } B . \\
\text { subtilis }\end{array}$ & [71] \\
\hline $\begin{array}{c}\text { L. digitata/S. } \\
\text { latissima/H. elongata/P. } \\
\text { palmata/C. } \\
\text { crispus-(Ireland) }\end{array}$ & $\begin{array}{l}\text { HAE, } \mathrm{MeOH}, \\
\text { EtOH, AcO, } 2 \text { h }\end{array}$ & $\begin{array}{l}\text { L. monocytogenes/S. abony/E. } \\
\text { faecalis/P. aeruginosa }\end{array}$ & $\begin{array}{l}\text { The extraction of } \\
\text { antimicrobials from } \\
\text { macroalgae were } \\
\text { solvent dependent }\end{array}$ & [72] \\
\hline marginatum-(India) & $\begin{array}{l}\text { HAE, DCM, EtOAc, } \\
\text { AcO, } \mathrm{MeOH}\end{array}$ & Candida spp. & $\begin{array}{l}\text { Low antifungal } \\
\text { properties. }\end{array}$ & [73] \\
\hline $\begin{array}{c}\text { S. lomentaria/P. } \\
\text { pavonica/C.mediterranea/ } \\
\text { H. musciformis/S. } \\
\text { filamentosa-(Turkey) }\end{array}$ & $\begin{array}{l}\mathrm{HAE}, \mathrm{MeOH}, 8 \mathrm{~h}, \\
200 \mathrm{rpm}\end{array}$ & $\begin{array}{l}\text { S. aureus/S. typhimurium/E. } \\
\text { coli/E. faecalis/C. albicans }\end{array}$ & $\begin{array}{c}\text { S. lomentaria } \\
\text { inhibited S. } \\
\text { typhimurium. C. } \\
\text { mediterranea } \\
\text { inhibited C. albicans }\end{array}$ & [74] \\
\hline $\begin{array}{c}\text { U. lactuca/E. } \\
\text { intestinalis-(Adriatic } \\
\text { coast of Montenegro) }\end{array}$ & $\begin{array}{l}\mathrm{HAE}, \mathrm{Hx}, \mathrm{DCM} \\
\mathrm{MeOH}, 72 \mathrm{~h}\end{array}$ & $\begin{array}{c}\text { B. mycoides/B. subtilis/E. } \\
\text { coli/K. } \\
\text { pneumoniae/S. aureus/A. } \\
\text { flavus/A. } \\
\text { fumigatus/C. albicans/P. } \\
\text { purpurascens/P. verrucosum }\end{array}$ & $\begin{array}{l}\text { Inhibitory effects } \\
\text { were observed } \\
\text { against B. mycoides } \\
\text { and B. subtilis }\end{array}$ & [75] \\
\hline $\begin{array}{c}\text { A. fragilis/C.a myrica/H. } \\
\text { cuneiformes } / L \text {. } \\
\text { papillosa/S. cinereum/T } \\
\text { turbinata-(Egypt) }\end{array}$ & $\begin{array}{c}\mathrm{HAE}, 80 \% \mathrm{MeOH}, \\
25^{\circ} \mathrm{C}\end{array}$ & $\begin{array}{l}\text { B. subtilis/S. aureus/E. } \\
\text { coli/C. albicans }\end{array}$ & $\begin{array}{c}\text { H. cuneiformis extract } \\
\text { showed stronger } \\
\text { activity }\end{array}$ & [76] \\
\hline E.cava-(Korea) & $\begin{array}{l}\mathrm{HAE}, \mathrm{EtOH}, n-\mathrm{Hx}, \\
\text { DCM, EtOAc, } \\
n-\mathrm{BuOH}, \mathrm{H}_{2} \mathrm{O}\end{array}$ & $\begin{array}{l}\text { S. aureus/MRSA/S. typhi/S. } \\
\text { enteritidis/S. gallinarum }\end{array}$ & $\begin{array}{c}\text { EtOH had } \\
\text { antibacterial activity } \\
\text { S. aureus, MRSA and } \\
\text { Salmonella spp. }\end{array}$ & [77] \\
\hline $\begin{array}{c}\text { C. barbata-(Red Sea, } \\
\text { Egypt })\end{array}$ & $\begin{array}{c}\text { Soxhlet extraction, } \\
\text { EtOH }\end{array}$ & $\begin{array}{c}\text { B. subtilis/S. aureus/M. } \\
\text { luteus/E. coli/P. } \\
\text { aeruginosa/Serratia. } \\
\text { marcescens/S. typhi/Vibrio } \\
\text { sp./A. hydrophila/C. albicans }\end{array}$ & $\begin{array}{c}\text { Inhibitory activity } \\
\text { except against } M . \\
\text { luteus }\end{array}$ & [78] \\
\hline K. alvarezii-(Malaysia) & $\mathrm{HAE}, \mathrm{EtOH}, \mathrm{H}_{2} \mathrm{O}$ & E. coli/B. cereus & $\begin{array}{c}\text { B. cereus was } \\
\text { inhibited but no } E \text {. } \\
\text { coli. }\end{array}$ & [79] \\
\hline $\begin{array}{c}\text { U. lactuca/D. } \\
\text { dichotoma/P. } \\
\text { gymnospora/S. } \\
\text { vulgare/H. musciformis/ } \\
\text { D. simplex-(Brazil) }\end{array}$ & $\begin{array}{c}\text { HAE, DCM, } \\
\mathrm{MeOH}, \mathrm{EtOH}, \mathrm{H}_{2} \mathrm{O}\end{array}$ & $\begin{array}{c}\text { T. rubrum/T. tonsurans/T. } \\
\text { mentagrophytes/M. canis/M. } \\
\text { gypseum/E. } \\
\text { flocossum/C. albicans/C. } \\
\text { krusei/C. guilliermondi/C. } \\
\text { parapsilosis/ }\end{array}$ & $\begin{array}{l}\mathrm{EtOH} \text { and } \mathrm{MeOH} \\
\text { extracts were the } \\
\text { most effective }\end{array}$ & [80] \\
\hline $\begin{array}{c}\text { B. } \\
\text { bifurcata-(Portugal) }\end{array}$ & $\begin{array}{l}\mathrm{HAE}, \mathrm{MeOH} \\
\mathrm{DCM}, 12 \mathrm{~h}\end{array}$ & $\begin{array}{c}\text { E. coli/P. aeruginosa/B. } \\
\text { subtilis/S. aureus/S. cerevisiae }\end{array}$ & $\begin{array}{l}\text { MeOH extracts had } \\
\text { inhibitory effects in } \\
\text { all the } \\
\text { microorganisms }\end{array}$ & [81] \\
\hline
\end{tabular}


Table 1. Cont.

\begin{tabular}{|c|c|c|c|c|}
\hline Alga Species & Conditions & Bacteria Tested & Main Outcomes & Ref. \\
\hline $\begin{array}{c}\text { H. flagelliformis/C. } \\
\text { myrica/S. } \\
\text { boveanum-(Persian } \\
\text { Gulf) }\end{array}$ & HAE, DCM, 48 h & $\begin{array}{c}\text { E. coli:/K. pneumonia/S. } \\
\text { typhi/S. aureus/S. } \\
\text { epidemidis/B. subtilis/A. } \\
\text { niger/C. albicans }\end{array}$ & $\begin{array}{l}\text { The antimicrobial } \\
\text { activity was } \\
\text { solvent-dependent }\end{array}$ & [82] \\
\hline T. conoides-(India) & $\begin{array}{l}\mathrm{HAE}, \boldsymbol{n}-\mathrm{Hx}, \mathrm{MeOH} \\
\text { and } \mathrm{EtOH}: \mathrm{H}_{2} \mathrm{O}, 72 \\
\text { h. }\end{array}$ & $\begin{array}{l}\text { S. aureus/S. epidermidis/E. } \\
\text { coli/P. aeruginosa/A. } \\
\text { niger/C. albicans }\end{array}$ & $\begin{array}{c}\mathrm{MeOH} \text { and EtOH: } \\
\mathrm{H}_{2} \mathrm{O} \text { extracts were } \\
\text { the most effective } \\
\text { against the } \\
\text { microorganisms } \\
\text { studied }\end{array}$ & [83] \\
\hline $\begin{array}{c}\text { D. dichotoma/P. } \\
\text { pavonica/S. } \\
\text { vulgare-(Adriatic } \\
\text { Sea) }\end{array}$ & $\begin{array}{c}\mathrm{HAE}, \mathrm{AcO}, 50^{\circ} \mathrm{C} ; 4 \\
\mathrm{~h}\end{array}$ & $\begin{array}{c}\text { B. mycoides/B. } \\
\text { subtilis/S. aureus/E. coli/K. } \\
\text { pneumoniae/A. flavus/A. } \\
\text { fumigatus/C. albicans/P. } \\
\text { purpurescens/P. verrucosum }\end{array}$ & $\begin{array}{l}\text { All crude extracts } \\
\text { have a statistically } \\
\text { significant inhibitory } \\
\text { effect on microbial } \\
\text { growth }\end{array}$ & [84] \\
\hline $\begin{array}{c}\text { C. racemosa/ } \\
\text { C. sertularioides/ } \\
\text { K. alvarezii } \\
\text {-(Malaysian coast) }\end{array}$ & $\begin{array}{c}\mathrm{HAE}, \mathrm{Hx}, \mathrm{CHCl}_{3}, \\
\text { EtOAc, EtOH, } \\
\mathrm{MeOH}, \mathrm{H}_{2} \mathrm{O}, 1 \text { day }\end{array}$ & $\begin{array}{c}\text { B. cereus/S. aureus/A. } \\
\text { baumannii/E. coli/K. } \\
\text { pneumoniae/P. } \\
\text { aeruginosa/C. albicans/C. } \\
\text { parapsilosis/C. krusei/C. } \\
\text { neoformans/A. fumigatus/T. } \\
\text { interdigitale }\end{array}$ & $\begin{array}{l}\text { Inhibitory effects } \\
\text { except against A. } \\
\quad \text { fumigatus }\end{array}$ & [85] \\
\hline $\begin{array}{l}\text { U. lactuca-(Gulf of } \\
\text { Maine) }\end{array}$ & $\mathrm{HAE}, \mathrm{MeOH}, 70^{\circ} \mathrm{C}$ & S. aureus/S. epidermidis & $\begin{array}{l}\text { Inhibitory effects } \\
\text { against both species }\end{array}$ & [86] \\
\hline $\begin{array}{l}\text { T. ornata/T. decurrens/ } \\
\text { T. conoides/ } \\
\text { S. polycystum/S. } \\
\text { incisifolium/S. } \\
\text { ilicifolium/H.a } \\
\text { cuneiformis_(Madagascar }\end{array}$ & $\begin{array}{l}\mathrm{HAE}, \mathrm{MeOH}, \\
\text { EtOAc }\end{array}$ & $\begin{array}{c}\text { B. cereus/S. aureus/S. } \\
\text { pneumoniae/E. cloacae/K. } \\
\text { oxytoca/S. boydii/E. coli/S. } \\
\text { enteridis/P. } \\
\text { aeruginosa/C. albicans/C. } \\
\text { membranaefaciens/C. } \\
\text { neoformans/T. mucoides }\end{array}$ & $\begin{array}{l}\text { Antimicrobial tests of } \\
\text { the crude extracts } \\
\text { revealed a strong } \\
\text { activity against } \\
\text { S. aureus and S. } \\
\text { pneumoniae }\end{array}$ & [87] \\
\hline $\begin{array}{c}\text { A. } \\
\text { specifera/Cladophoropsis } \\
\text { sp./L. } \\
\text { paniculata/Tydemania } \\
\text { sp./U. prolifera }\end{array}$ & $\begin{array}{l}\text { Soxhlet extraction, } \\
\text { EtOH and PeEt, } \\
24 \mathrm{~h}\end{array}$ & $\begin{array}{l}\text { C. albicans/A. niger/Mucor } \\
\text { sp./Paeciliomyces sp. }\end{array}$ & $\begin{array}{c}\text { EtOH extract of } L \text {. } \\
\text { paniculata showed } \\
\text { the best antimicrobial } \\
\text { activity }\end{array}$ & [88] \\
\hline $\begin{array}{c}\text { H. esperi/C. } \\
\text { prolifera-(Egypt) }\end{array}$ & $\begin{array}{l}\text { Soxhlet extraction, } \\
\mathrm{MeOH}, 40^{\circ} \mathrm{C}, 24 \mathrm{~h}\end{array}$ & $\begin{array}{l}\text { E. coli/P. aeruginosa/S. } \\
\text { typhimurium/A. } \\
\text { hydrophila/B. } \\
\text { subtilis/S. aureus }\end{array}$ & $\begin{array}{l}\text { Inhibitory effects } \\
\text { against } B \text {. subtilis and } \\
\text { S. aureus growth but } \\
\text { no against } P \text {. } \\
\text { aeruginosa and } S \text {. } \\
\text { typhimurium, }\end{array}$ & [89] \\
\hline $\begin{array}{l}\text { Grateloupia sp./G. } \\
\text { corticata/Halymenia } \\
\text { sp./Metamastophora } \\
\text { sp./Spyridia sp. }\end{array}$ & $\mathrm{HAE}, \mathrm{MeOH}, 24 \mathrm{~h}$ & $\begin{array}{c}\text { E. cloacae/K. oxytoca/E. coli/S. } \\
\text { enteridis/B. } \\
\text { cereus/S. aureus/S. } \\
\text { pneumoniae/C. albicans. }\end{array}$ & $\begin{array}{l}\text { All the crude extracts } \\
\text { obtained can inhibit } \\
\text { microbe's growth. }\end{array}$ & [90] \\
\hline H. elongata-(Ireland) & $\begin{array}{l}\mathrm{HAE}, \mathrm{H}_{2} \mathrm{O}, \mathrm{MeOH} \\
40^{\circ} \mathrm{C}, 100 \mathrm{rpm}, 2 \mathrm{~h}\end{array}$ & $\begin{array}{l}\text { L. monocytogenes/S. abony/E. } \\
\text { faecalis/P. aeruginosa }\end{array}$ & $\begin{array}{l}60 \% \mathrm{MeOH} \text { extract } \\
\text { showed the best } \\
\text { results. }\end{array}$ & [91] \\
\hline $\begin{array}{c}\text { F. serratus/F. } \\
\text { vesiculosus-(Ireland) }\end{array}$ & $\begin{array}{l}\mathrm{HAE}, \mathrm{H}_{2} \mathrm{O}, \mathrm{MeOH}, \\
\text { EtOAc, } \mathrm{AcO}\end{array}$ & MRSA 28 strains & $\begin{array}{l}\text { Both species present } \\
\text { antibacterial activity } \\
\text { against several } \\
\text { MRSA strains. }\end{array}$ & [92] \\
\hline $\begin{array}{c}U . \\
\text { reticulata-(Vietnam) }\end{array}$ & $\begin{array}{c}\mathrm{HAE}, \\
\mathrm{MeOH}: \mathrm{CHCl}_{3} \text { : } \\
\mathrm{H}_{2} \mathrm{O}\end{array}$ & $\begin{array}{c}\text { B. cereus/S. faecalis/E. } \\
\text { cloace/S. aureus/E. coli/P. } \\
\text { aeruginosa/V. haveyi }\end{array}$ & $\begin{array}{c}\text { U. reticulata showed } \\
\text { high antimicrobial } \\
\text { activity, against } E . \\
\text { cloace and against } E . \\
\text { coli. }\end{array}$ & [93] \\
\hline
\end{tabular}


Table 1. Cont.

\begin{tabular}{|c|c|c|c|c|}
\hline Alga Species & Conditions & Bacteria Tested & Main Outcomes & Ref. \\
\hline U. rigida-(Tunisia) & $\begin{array}{c}\mathrm{HAE}, \mathrm{EtOH}: \mathrm{H}_{2} \mathrm{O} \\
48\end{array}$ & $\begin{array}{c}\text { B. subtilis/B. } \\
\text { cerus/S. aureus/S. } \\
\text { epidermis/E. faecalis/L. } \\
\text { monocytogenes/E. coli/P. } \\
\text { aeruginosa/K. pneumoniae/A. } \\
\text { niger/F. graminearum/F. } \\
\text { culmorum/F. } \\
\text { oxysporum/C. albicans }\end{array}$ & $\begin{array}{l}\text { Antimicrobial } \\
\text { activity varied } \\
\text { depending on the } \\
\text { season }\end{array}$ & [94] \\
\hline $\begin{array}{c}\text { U. fasciata/G. } \\
\text { salicornia-(Honolulu, } \\
\text { USA) }\end{array}$ & $\mathrm{HAE}, \mathrm{EtOH}$ & $\begin{array}{c}\text { E. faecalis/V. alginolyticus/V. } \\
\text { cholerae/S. aureus/S. } \\
\text { typhimurium/E. coli }\end{array}$ & $\begin{array}{c}\text { U. fasciata had } \\
\text { significantly higher } \\
\text { antimicrobial activity } \\
\text { compared to } G \text {. } \\
\text { salicornia }\end{array}$ & [95] \\
\hline $\begin{array}{c}\text { U. lactuca/D. } \\
\text { dichotoma/C. } \\
\text { elongata-(Algeria) }\end{array}$ & $\begin{array}{c}\mathrm{HAE}, \mathrm{MeOH}^{\mathrm{DEt}}, \\
\mathrm{CHCl}_{3}\end{array}$ & $\begin{array}{l}\text { E. coli/S. aureus/Salmonella/ } \\
\text { C. albicans/Penicillium sp. }\end{array}$ & $\begin{array}{l}\mathrm{CHCl}_{3} \text { extracts of } U \text {. } \\
\text { lactuca and } \mathrm{C} \text {. } \\
\text { elongata had the } \\
\text { highest activity } \\
\text { against } E \text {. coli and } \\
\text { Salmonella sp. MeOH } \\
\text { of all species showed } \\
\text { antifungal activity } \\
\text { for C. albicans. }\end{array}$ & [96] \\
\hline
\end{tabular}

Conditions: Heat-assisted extraction (HAE) Acetone (AcO), Ethanol (EtOH), Methanol (MeOH); Dichloromethane $(\mathrm{DCM})$, Water $\left(\mathrm{H}_{2} \mathrm{O}\right)$, Hexane (Hex), Dimethilsulfoxide (DMSO), Chloroform $\left(\mathrm{CHCl}_{3}\right)$, Petroleum ether (PeEt), Ethyl acetatete (EtOAc), Diethyl ether (DEt), $n$ - Butanol $(n-\mathrm{BuOH}), n$-Hexane $(n-\mathrm{Hx})$. Main outcomes: Minimal inhibitory concentration (MIC).

\section{Macroalgae as a Promising Source of Valuable Antimicrobial Compounds}

The nutritional composition of seaweed is strongly influenced by factors such as the species, environmental conditions, geographical place, seasonality and characteristics of the growth medium as well as by the developmental stage [97]. Seaweeds are an excellent source of biologically active compounds that includes proteins and peptides, polysaccharides, polyphenols, PUFAs and pigments [98,99]. The resistance of pathogenic microorganisms to synthetic antibiotics has become a concern of public health systems [33] and therefore, it is imperative to explore new alternatives to solve this problem. In particular, among the different compounds that exhibit bioactivity that are present in macroalgae, interest in their antimicrobial potential has increased in the last few years in order to develop new antimicrobial therapies with less secondary effects, that are more cost effective and with minor toxicity, when compared to the synthetic antibiotics [33]. Although research on the antimicrobial properties of seaweed compounds is a topic of great interest, until now the attribution of a particular compound to such activity was a challenge as they are usually evaluated as extracts and not as a compound constituted by different biomolecules; in most cases, the antimicrobial effect is probably a consequence of a synergic effect between these compounds. The main components of seaweeds are described in the following sections.

\subsection{Protein and Peptides}

The protein content is highly variable, ranging between 10 to $30 \%$ of the dry weight (DW) in red seaweeds, from 5 to $15 \%$ DW in brown seaweeds and from 3 to $47 \%$ DW in green seaweeds $[9,97]$. Moreover, these contents vary depending on the season, founding the highest concentration during the winter-early spring and the lowest during summer-early autumn $[97,100,101]$. The proteins that are actively functional in seaweeds belong to two groups, namely, lectins and phycobiliproteins $[14,102]$. Particularly, whereas lectins have been identified in several species of seaweeds, phycobiliproteins are found in red macroalgae [102]. 
Protein from seaweeds contains all amino acids, chiefly glycine, alanine, arginine, proline, glutamic and aspartic acids [103]. However, seaweeds present reduced content of lysine, threonine, tryptophan, cysteine and methionine in comparison with other protein foods [102]. Peptides obtained from seaweeds have experienced an increasing interest in recent years due to their multiple bioactivity compounds (angiotensin converting enzyme inhibition, antihypertensive, antioxidative and antidiabetic) [104].

Regarding the antimicrobial activity, the only seaweed protein described in the literature as antibacterial is lectin [14,105]. The information about bioactive peptides with antibacterial properties is scarce. For example, Beaulieu et al. (2015) obtained antibacterial peptides after hydrolysis of proteins from macroalgae $S$. longicruris. These authors evaluated the antibacterial activity of the $>10 \mathrm{kDa}$ protein hydrolysate fraction against $S$. aureus and observed a significant decrease in the maximum specific growth rate when using a quantity between $0.31 \mathrm{mg} / \mathrm{mL}$ to $2.5 \mathrm{mg} / \mathrm{mL}$ [105]. Another example is the study by Cordeiro et al. (2006), which extracted protein fractions rich in lectin from the red seaweed H. musciformis and assessed its antifungal properties against human pathogen yeasts C. albicans and C. guilliermondii. Specifically, the F40/70 fraction demonstrated the capacity to inhibit the growth of C. guilliermondii at 45,100 and $450 \mu \mathrm{g}$ protein/mL, but a poor inhibition was observed against C. albicans independent of the evaluated concentrations [106]. Lectin was also isolated from red macroalgae S. filiformis [107]. Antibacterial activity was assessed on the growth of eight Gram-negative (E. coli, S. marcescens, S. typhi, S. typhimurium, K. pneumoniae, E. aerogenes, Proteus spp, and Pseudomonas aeruginosa) and three Gram-positive (B. cereus, B. subtilis and S. aureus). The authors found different results regarding the effects of lectin against Gram-negative and Gram-positive bacteria growth. The lectin at $500 \mu \mathrm{g} / \mathrm{mL}$ stimulated the growth of B. cereus and inhibited the growth of $S$. marcescens, $S$. typhi, K. pneumoniae, E. aerogenes, Proteus sp, and P. aeruginosa at $1000 \mu \mathrm{g} / \mathrm{mL}$. The compound did not exhibit an effect, at any of the tested concentrations, on the growth of S. aureus and B. subtilis, or on E. coli and $S$. typhimurium. The authors concluded that more studies are necessary to evaluate the action of lectin on bacterial growth in order to evaluate further clinical applications.

\subsection{Polysaccharides}

Polysaccharides are the main components of seaweeds, having a structural role in algal cell walls [108]. Polysaccharides can be neutral or acidic, linear or branched [108]. Green, red and brown algae are defined by the presence of sulfated polysaccharides with a high degree of complexity in the range from $4 \%$ to $76 \%$ DW [109]. In green seaweeds, polysaccharides represent between 38 and $54 \%$ of their dry matter [110]. These macroalgae are rich in ulvan (another sulfate polysaccharide), sulfated rhamnans and sulfated galactans. The main component of these polysaccharides are sulfate groups and moreover they contain repeating units of rhamnose, xylose and uronic acids (glucuronic and iduronic acids) and minor contents of glucose, galactose, rhamnose and arabinose [110]. Red seaweeds present different sulfated galactans, sulfated rhamnans or mannans, carrageenans and agars. The main polysaccharides found in red macroalgae are galactans with a backbone composed of repeating units of three-linked $\beta$-D-galactopyranosyl and four-linked $\alpha$-galactopyranosyl units: if the configuration of the four-linked $\alpha$-galactopyranosyl units is $\mathrm{L}$ the polysaccharide is agar and if the configuration of the four-linked $\alpha$-galactopyranosyl units is D then the polysaccharide is carrageenan. Agars are typically low in sulfate ester substitution, whereas carrageenans are comparatively rich in sulfate ester substitution [111]. Brown macroalgae are a rich source of alginate with a content that varies between 14 and $40 \%$ of their dry mass [7]. After the alginates, $\beta$-glucans (laminarans), cellulose and heteroglycans are present in important amounts in brown algae [7]. Laminarans are $\beta$-D-glucans with low molecular weight that are linear polysaccharides of glucose linked by $1 \rightarrow 3 \beta$-glycosidic bonds. There are different types of laminarans classed in accordance of their length and branching degree. Laminarans contain some 6-O-branches in their backbone and some $\beta-(1 \rightarrow 6)$-intrachain links. Fucoidans are a family of sulfated homo and heteropolysaccharides that are mainly composed of $(1 \rightarrow 3)$-linked-L-fucopyranose units. Moreover, fucoidans can present a main chain of alternating $(1 \rightarrow 3)$ and $(1 \rightarrow 4)$-linked-L-fucopyranose units, and sulfate groups located mainly at C2, C4, or disubstituted 
at both $\mathrm{C} 2$ and $\mathrm{C} 4$. In addition, acetyl groups and D-galactose, D-xylose, D-mannose, L-rhamnose and D-glucuronic acid residues were identified as components of fucoidans [112].

The antimicrobial activity of polysaccharides from seaweeds depends on factors such as molecular weight, charge density, sulfated content in the case of sulfated polysaccharides and structural and conformation characteristics [33]. Several studies have been reported. For example, sulphated polysaccharides (alginates, fucoidans and laminaran) extracted from different seaweeds, such as L. japonica, A. nodosum, or U. pinnafitida have demonstrated an inhibitory effect on the growth of pathogenic bacteria [113]. Similarly, extracts rich in either laminarin or fucoidan isolated from Laminaria spp, decreased the fecal E. coli populations in piglets $(0.3$ and $0.24 \mathrm{~g} / \mathrm{kg}$, respectively), observing a reduction in the initial bacterial load in derived raw meat products [114].

\subsection{Fatty Acids}

Seaweeds produce PUFAs and are also important sources of essential fatty acids [115-117]. The most predominant PUFAs are $\omega 3$ such as $16: 4 \omega 3$ and 18:4 $\omega 3$ and some species also present important amounts of eicosapentaenoic acid (20:5 $\omega 3$, EPA) [118], $\alpha$-linolenic (18:3 $\omega-3)$,


antimicrobial properties of macroalgal fatty acids. For example, different sulfolipid classes isolated from the total lipids of two species of $U$. fasciata (Chlorophyta), L. papillosa, G. cylindriea (Rhodophyta), D. fasciola and T. atomaria (Ochrophyta). Authors assessed the antimicrobial activity of these compounds and they observed a high inhibition of the growth of B. subtilis and E. coli, using $100 \mu \mathrm{g} / \mathrm{well}$. However, these compounds did not exhibit any inhibition against the fungi or yeast tested [119]. Another study obtained G. vermiculophylla, P. dioica and C. crispus using solvents with different polarity (DEt $<$ EtOAc $\left.<\mathrm{MeOH}: \mathrm{H}_{2} \mathrm{O}(1: 1)\right)$. The authors identified the fatty acid profile of ethyl acetate extracts and observed that saturated fatty acids (SFA), especially palmitic acid (16:0) was the more abundant, followed by polyunsaturated fatty acids (PUFA) and monounsaturated fatty acids (MUFA). They tested the antimicrobial activity against Gram-positive bacteria (L. innocua, B. cereus, E. faecalis, L. brevis, S. aureus and Gram negative (E. coli, S. enteritidis, P. aeruginosa) and the yeast Candida sp. The EtOAc extract showed the high inhibition capacity of the tested strains [17].

\subsection{Polyphenolic Compounds}

Polyphenolic compounds are secondary metabolites of seaweeds whose composition vary from simple phenolic acids to complex molecules such as phlorotannins [120]. Macroalgae are excellent sources of catechins, flavonols and phlorotannins [121,122]. Green and red algae contain high proportions of bromophenols, phenolic acids and flavonoids. Brown algae present predominant polyphenolic compounds such us phlorotannins, which are complex polymers of phloroglucinol (1,3,5-trihydroxybenzene), and are classified into different groups in function of the bonds of the phloroglucinol units. They are divided in eckols and carmalols (dibenzodioxin linkage), fuhalols (ether bonds and hydroxyl groups), fucophlorethols (ether and phenyl bonds), phlorethols (ether bonds), fucols (phanyl linkages), and ishofuhalols [121,123]. In addition, some brown algae can contain bromo-, chloro- and iodo-phlorotannins [123]. These compounds represent $20 \%$ DW of algae [120] and have only been described in the composition of brown algae [123]. Other polyphenols such as catechins, flavonoids and flavonol glycosides have been identified in brown seaweeds [124].

Referring to the antimicrobial activity of polyphenols, several authors have studied the properties of phlorotanins. In this context, Nagayama et al. (2002) [125] evaluated the antibacterial effect of phlorotannins from E. kurome against several food-borne pathogenic bacteria, different MRSA strains and S. pyogenes. They observed that the phlorotannins were effective against MRSA and also Campylobacter spp., which presented the highest susceptibility to these compounds. The minimal bactericidal concentration of the crude phlorotannins, dieckol and 8,8'-bieckol against $C$. jejuni were $50 \mathrm{mg} / \mathrm{L}, 0.03 \mu \mathrm{mol} / \mathrm{mL}$ and $0.03 \mu \mathrm{mol} / \mathrm{mL}$, respectively [125]. 


\subsection{Pigments}

Based on their content in pigments, macroalgae are classified into three groups: green algae (Chlorophyta, ca. 1200 species), red algae (Rhodophyta, ca. 6000 species) and brown algae (Ochrophyta, ca. 1750 species). Macroalgae are described to present three types of natural pigments: chlorophylls, carotenoids and phycobilins. Chlorophylls are greenish lipid-soluble natural pigments which contain a porphyrin ring and are found in all algae [102]. Four forms of chlorophylls have been identified in macroalgae with the most important being chlorophyll a; chlorophyll $\mathrm{b}$ and $\mathrm{c}$ are also described and the chlorophyll $\mathrm{d}$ is present in red algae [102]. Phycobiliproteins are other natural pigments and are water soluble fluorescent proteins present in seaweeds [126,127]. There are three types of phycobiliproteins: phycocyanins (blue pigment), phycoerytrins (red pigment) and allophycocyanins (light-blue pigment) [102,126], with phycoerytrins being the most abundant in many red macroalgae species. Carotenoids are linear polyenes and can be classified in carotenes ( $\alpha$ y $\beta$-carotene, lycopene) and xanthophylls (fucoxanthin, violaxanthin, antheraxanthin, zeaxanthin, lutein, neoxanthin). The most abundant carotenoid is fucoxanthin, a brown pigment that confers the coloration to brown algae [102].

Regarding the antimicrobial activity of pigments, there are few studies that evaluate the activity of isolated compounds. A recent study has evaluated the antimicrobial properties of fucoxanthin against different Gram-positive and Gram-negative bacteria. The results showed that the compound was more effective against Gram-positive bacteria, with $S$. agalactiae being the most affected bacteria (with a MIC of $62.5 \mu \mathrm{g} / \mathrm{mL}$ ), followed by S. epidermidis and S. aureus [128].

\section{Mechanisms of Action of Antimicrobial Compounds}

In the previous section, numerous compounds extracted from macroalgae with proven antimicrobial activity are mentioned. In the following paragraphs, the mechanisms of action of these compounds will be explained. A summary of these mechanisms is presented in (Figure 2). In Table 2, several studies demonstrating the antimicrobial properties of macroalgae compounds have been compiled.

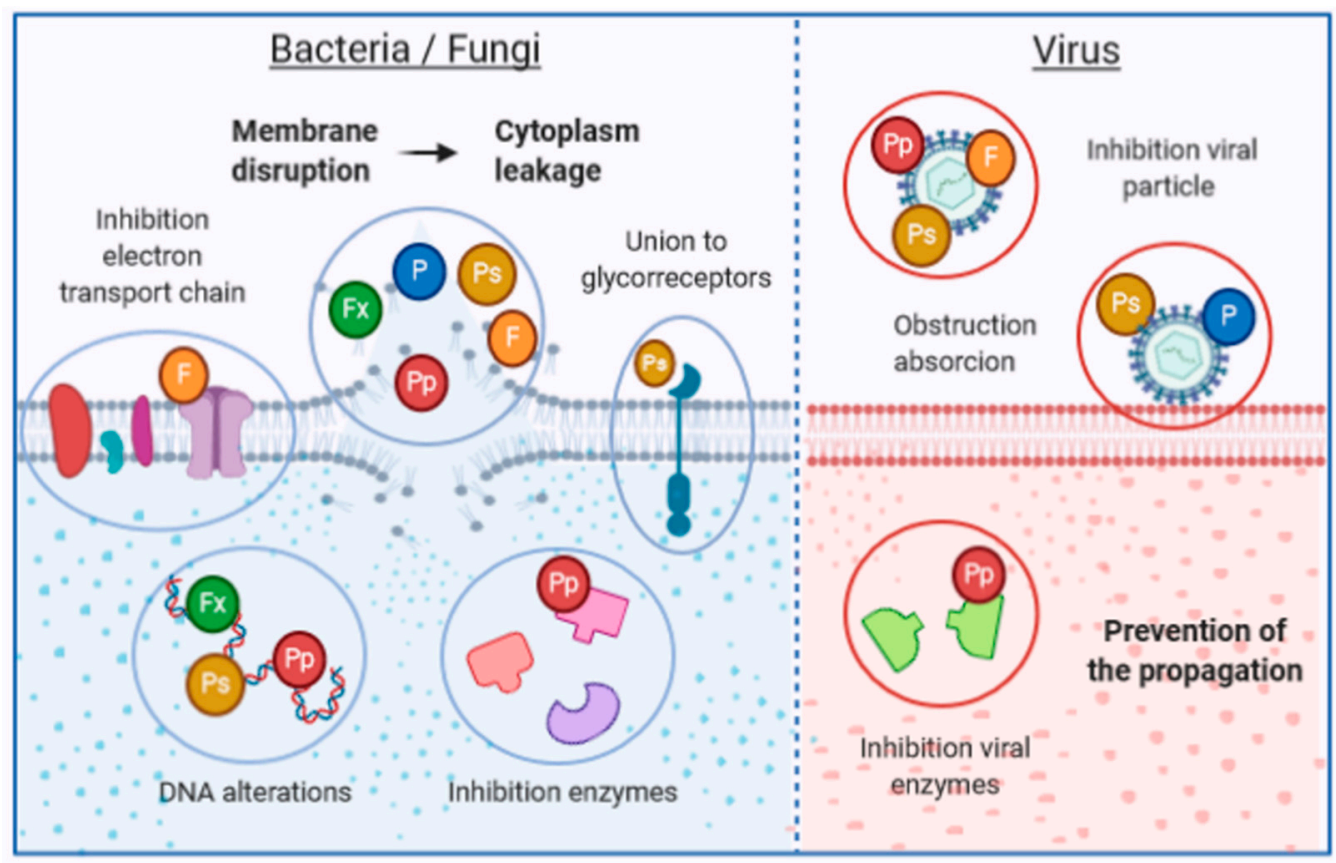

Figure 2. Schematic illustration of the main action mechanisms of antimicrobial compounds extracted from macroalgae species. 
Table 2. Antimicrobial properties of compounds extracted from macroalgae.

\begin{tabular}{|c|c|c|c|c|}
\hline Type & Compounds & Macroalgae & Antimicrobial Activity & Ref. \\
\hline \multirow{8}{*}{ Polyphenols } & Phlorotannins & F. vesiculosus & $\begin{array}{l}\text { Alteration of the cell } \\
\text { membrane and cell } \\
\text { destruction of } S \text {. aureus, } \\
\text { S. pneumonia and } P \text {. } \\
\text { aeruginosa }\end{array}$ & [129] \\
\hline & Phlorotannins & S. thunbergii & $\begin{array}{c}\text { Alteration of the cell } \\
\text { membrane, cytoplasm's } \\
\text { leakage and cell destruction } \\
\text { of } V \text {. parahaemolyticus }\end{array}$ & [130] \\
\hline & Phlorofucofuroeckol & E. bicyclis & $\begin{array}{l}\text { Cell membrane damage and } \\
\text { suppression of genes related } \\
\text { to methicillin resistance in } \\
\text { S. aureus }\end{array}$ & [131] \\
\hline & Bromophenols & K. alvarezii & $\begin{array}{c}\text { Downregulation of } \\
\text { pathogenic genes of } \\
\text { P. gingivalis }\end{array}$ & [132] \\
\hline & Dieckol & E. clava & $\begin{array}{l}\text { Alteration of cell integrity } \\
\text { and metabolism of T. rubrum }\end{array}$ & [133] \\
\hline & Phlorotannins & $\begin{array}{l}\text { C. nodicaulis, } \\
\text { C. usneoides, } F \text {. } \\
\text { spiralis }\end{array}$ & $\begin{array}{l}\text { Alterations of the cell wall } \\
\text { composition, increased } \\
\text { mitochondrial respiration. } \\
\text { Inhibition of the formation } \\
\text { of the germ tube of } \\
\text { C. albicans }\end{array}$ & [134] \\
\hline & Phlorotannins & E. clava & $\begin{array}{l}\text { Inhibition of the enzyme } \\
\text { neuraminidase of the } \\
\text { Influenza A virus }\end{array}$ & [135] \\
\hline & $\begin{array}{l}\text { Polyphenolic rich } \\
\text { extracts }\end{array}$ & $\begin{array}{l}\text { E. arborea, } \\
\text { S. filiformis }\end{array}$ & $\begin{array}{l}\text { Inhibition of the viral } \\
\text { particle }\end{array}$ & [136] \\
\hline \multirow{5}{*}{ Polysaccharides } & $\begin{array}{l}\text { Depolymerized } \\
\text { fucoidans }\end{array}$ & L. japonica & $\begin{array}{l}\text { Interaction with protein of } \\
\text { the cell membrane and } \\
\text { cellular rupture of E. coli and } \\
\text { S. aureus }\end{array}$ & [137] \\
\hline & Fucoidan & F. vesiculosus & $\begin{array}{l}\text { Inhibition of dental plaque } \\
\text { bacteria and foodborne } \\
\text { pathogens. }\end{array}$ & [138] \\
\hline & $\begin{array}{l}\text { Laminarin rich } \\
\text { extracts }\end{array}$ & $\begin{array}{l}\text { A. nodosum, } L \text {. } \\
\text { hyperborea }\end{array}$ & $\begin{array}{l}\text { Inhibition of } S . \text { aureus, } L \text {. } \\
\text { monocytogenes, E. coli and } S \text {. } \\
\text { typhimurium. }\end{array}$ & [139] \\
\hline & $\begin{array}{l}\text { Water soluble } \\
\text { polysaccharide } \\
\text { extracts }\end{array}$ & $\begin{array}{l}\text { P. capillacae, } D . \\
\text { membranacea }\end{array}$ & $\begin{array}{c}\text { Inhibition of F. oxysporium } \\
\text { Inhibition of C. albicans and } \\
M . \text { phaseli } \\
\text { Obstruction of herpes }\end{array}$ & [140] \\
\hline & $\begin{array}{c}\text { Sulfated } \\
\text { polysaccharides }\end{array}$ & C. okamuranus & $\begin{array}{l}\text { simplex virus type } 1 \text { and } 2 \\
\text { attachment to the cells } \\
\text { Interference with fusion } \\
\text { between HIV infected cells. } \\
\text { Inhibition of the viral } \\
\text { enzyme reverse transcriptase } \\
\text { Inhibition of dengue virus } \\
\text { by interaction with the } \\
\text { glycoprotein of the viral } \\
\text { envelop }\end{array}$ & [141] \\
\hline
\end{tabular}


Table 2. Cont.

\begin{tabular}{|c|c|c|c|c|}
\hline Type & Compounds & Macroalgae & Antimicrobial Activity & Ref. \\
\hline \multirow{5}{*}{ Proteins \& peptides } & Lectins & $\begin{array}{l}\text { E. serra, G. } \\
\text { marginata }\end{array}$ & $\begin{array}{l}\text { Inhibition of the growth of } V \text {. } \\
\text { vulnificus and } V \text {. pelagicus. } \\
\text { Interaction between lectins } \\
\text { and components of the } \\
\text { bacterial cell wall }\end{array}$ & [25] \\
\hline & $\begin{array}{l}\text { Protein hydrolysate } \\
\text { fraction }\end{array}$ & S. longicruris & $\begin{array}{c}\text { Inhibition of } S \text {. aureus } \\
\text { growth }\end{array}$ & [105] \\
\hline & Lectins & S. filiformis & $\begin{array}{c}\text { Inhibition of several } \\
\text { Gram-negative bacteria by } \\
\text { interaction with compounds } \\
\text { of the cell wall }\end{array}$ & [142] \\
\hline & Lectins & H. musciformis & $\begin{array}{l}\text { Inhibition of T. rubrum and } \\
\text { C. lindemuthianum }\end{array}$ & \\
\hline & Lectins & $\begin{array}{l}\text { B. coacta, Griffithsia } \\
\text { sp. }\end{array}$ & $\begin{array}{l}\text { Antiviral effects against HIV, } \\
\text { Hepatitis } C \text { virus and } \\
\text { SARS-CoV by preventing } \\
\text { the entry in the host cells }\end{array}$ & [143] \\
\hline \multirow{5}{*}{ Fatty acids } & Bioactive fraction & $\begin{array}{l}\text { S. vulgare, } S . \\
\text { fusiforme }\end{array}$ & $\begin{array}{c}\text { Perforation of the cell wall of } \\
\text { S. aureus and K. neumoniae, } \\
\text { cytoplasmic leakage and cell } \\
\text { death }\end{array}$ & [144] \\
\hline & Bioactive fraction & G. edulis & $\begin{array}{l}\text { Rupture of cell membrane of } \\
\text { Vibrio spp and } A \text {. hydrophila } \\
\text { Fatty acids could be }\end{array}$ & [145] \\
\hline & Bioactive fraction & $\begin{array}{l}\text { S. marginatum, } U \text {. } \\
\text { lactuca }\end{array}$ & $\begin{array}{c}\text { involved in the inhibition } \\
\text { S. aureus, E. coli and } P \text {. } \\
\text { vulgaris }\end{array}$ & [146] \\
\hline & Bioactive fraction & B. tenella & $\begin{array}{c}\text { Inhibition of } C \text {. } \\
\text { cladosporioides and } C \text {. } \\
\text { sphaerospermum by } \\
\text { disrupting the cell } \\
\text { membrane }\end{array}$ & [147] \\
\hline & $\begin{array}{l}\text { Sulfoquinovosyldia- } \\
\text { cylglycerol }\end{array}$ & C. racemosa & $\begin{array}{c}\text { Antiviral effects against HSV } \\
\text { type } 2 \text { by disturbing the } \\
\text { initial stages of the viral life } \\
\text { cycle }\end{array}$ & [148] \\
\hline \multirow[b]{2}{*}{ Pigments } & Fucoxanthin & H. elongata & $\begin{array}{l}\text { Inhibition of } L . \\
\text { monocytogenes }\end{array}$ & [149] \\
\hline & Fucoxanthin & Commercial extract & $\begin{array}{c}\text { Inhibition of several } \\
\text { pathogenic bacteria by } \\
\text { increasing cell membrane } \\
\text { permeability, leakage of } \\
\text { cytoplasm and inhibition of } \\
\text { nucleic acid }\end{array}$ & [128] \\
\hline
\end{tabular}

In the case of proteins and peptides, their inhibitory effects are associated with their amphiphilic nature, which allows them to interact with polar and non-polar sites of the membranes. The interaction leads to the apparition of pores, causing disruption of the membrane and cellular rupture. These compounds have demonstrated antibacterial activity against bacteria, such as P. aeruginosa, K. pneumoniane, S. typhi. or B. subtilis [23]. However, in many cases, the mechanism of action is not yet understood. Lectins isolated from macroalga have gained attention due to their great range of bioactivities. E. serra and G. marginata lectins showed antibacterial activity against $V$. vulnificus and $V$. pelagicus through the interaction between these compounds and components of the bacterial cell wall, such as lipopolysaccharides or peptidoglycans [25]. Lectins extracted from S. filiformis presented inhibitory effects against Gram-negative bacteria, like S. marcescens, S. typhi, K. pneumoniae, E. aerogenes, 
Proteus sp. and P. aeruginosa. This effect was associated with the interaction between glycol-compounds present on the cell wall. In a similar way, lectins extracted from macroalga $H$. musciformis exhibited antifungal activity against T. rubrum and C. lindemuthianum [142]. They have also displayed antiviral effects against human immunodeficiency, hepatitis $C$, severe acute respiratory syndrome coronavirus (SARS-CoV) viruses, mainly by preventing the entry of the virus in the host cells and thereby their propagation [143].

The antimicrobial properties of macroalgae polysaccharides are attributed to the interaction between glyco-receptors of the bacterial cell wall, compounds of the membrane and nucleic acids and the polysaccharides. Those interactions lead to the disruption of the membrane stability and cellular functions [34]. Several factors have been shown to influence this activity, such as the molecular weight, charge density, structure and conformation [20]. Sulfated polysaccharides have demonstrated their antibacterial activity in several studies. For example, depolymerized fucoidans of L. japonica showed antibacterial activity against E. coli and S. aureus, which is caused by the interaction of fucoidans with membrane proteins, leading to membrane rupture and further cell death [137]. In other study, sulfated polysaccharides were extracted from different marine macroalgae and their antibacterial and antibiofilm properties were assessed against dental plaque bacteria. Fucoidan extracted from F. vesiculosus inhibited the mentioned bacteria and foodborne pathogens. In this case, the results suggest that fucoidan may not present a direct killing effect and may act by trapping nutrients, reducing the bioavailability [138]. To our knowledge, few studies have evaluated the antifungal properties and mechanisms of algal polysaccharides. Water soluble polysaccharides extracted from P. capillacea and D. membranacea displayed antifungal activity against different yeast and fungi. P. capillacea inhibited the growth of F. oxysporium, while D. membranacea inhibited C. albicans and M. phaseli. In future studies, it is expected that the compounds involved in this activity, as well as their mechanisms of action will be identified [140]. Regarding antiviral effects, these have been studied more extensively. Macroalgal polysaccharides can inhibit the multiplication of viruses such as the herpes simplex virus (HSV), human immunodeficiency virus (HIV) or the dengue virus. They can also obstruct the interaction between viruses and cells and inhibit enzymes [141]

The antibacterial activity of algal lipids and fatty acids has been attributed to their ability to inhibit the electron transport chain and oxidative phosphorylation in cell membranes, leading to the formation of peroxidation and auto-oxidation degradation products and the cellular lysis [34,145]. To our knowledge, no studies have isolated and then tested the antibacterial activity of macroalga fatty acids, but they have been successfully identified in bioactive extracts. In the study by El Shafay et al. [144], fatty acids were identified in the bioactive fraction of the extracts of S. vulgare and $S$. fusiforme, but no isolation was performed. The analysis demonstrated that the cell wall of $S$. aureus and K. pneumoniae was perforated, which resulted in the rupture of the cell wall, leakage of the cytoplasm and further cell death. Similarly, fatty acids were detected in the active fractions extracted from the red algae G. edulis. Although fatty acids were not isolated and their antimicrobial activity was not separately verified, authors attributed the antibacterial effects against Vibrio spp. and A. hydrophila to these compounds [145]. In the case of fungi, it has been proposed that fatty acids may act in disrupting the cell membrane, inhibiting the reproduction. Antifungal activity has been observed against C. cladosporioides and C. sphaerospermum, in addition to antiprotozoal effects against T. cruzi and L. amazonensis [147]. A sulfoquinovosyldiacylglycerol isolated from the $n$ - BuOH fraction of C. racemosa showed antiviral effect against HSV type two by disturbing the early stage of the viral life cycle [148].

Among the literature, the most studied antimicrobial compounds are the polyphenols. Their antimicrobial action has been associated with their ability to alter membrane permeability (causing cell lysis), inhibit enzymes and different metabolic pathways, bind to surface molecules and other mechanisms. This activity seems to be related to the number of hydroxyl groups and also the degree of polymerization [20,23]. Several studies have assessed the antimicrobial properties and the diverse action mechanisms of polyphenols. For example, a recent study evaluated the antibactericidal action of phlorotannins (a type of polyphenol found in macroalgae of the class Phaeophyta) extracted from 
F. vesiculosus. The results showed that these compounds presented a significant bactericidal effect against $S$. aureus, S. pneumonia and P. aeruginosa. Phlorotannins presented a higher effectivity against Gram-positive bacteria than against Gram-negative bacteria, probably due the differences between their cell membranes, since Gram-negative bacteria are surrounded by an outer membrane which is rich in polysaccharides. The authors attributed the observed effects to the ability of phlorotannins to inhibit bacterial growth by the alteration of the cell membrane [129]. Similarly, phlorotannins from $S$. thunbergii have ben demonstrated to inhibit V. parahaemolyticus, causing damage to the cell wall and the membrane, which increased the membrane permeability and caused further leakage and destruction of the bacterial cells [130]. A phlorofucofuroeckol of the brown macroalga E. bycliclis has shown antibacterial effects against methicillin-resistant $S$. aureus. This compound produced damage in the cell membrane, leading to the leakage of cytoplasm and cell death. Furthermore, this compound suppressed the expression of genes related to resistance to methicillin in a dose-dependent manner [131]. Bromophenols, extracted from the red macroalga K. alvarezii, showed activity against $P$. gingivalis, the principal agent of chronic periodontitis. These compounds were able to downregulate the expression of the proteins involved in the infectious pathways of the bacteria [132]. Regarding yeast and fungi, the phlorotannin dieckol, extracted from E. clava, was tested against the fungi T. rubrum, associated with dermatophytic nail infections. The results exhibited alterations in membrane integrity and also in cell metabolism [133]. Another study evaluated the antifungal properties of the phlorotannins extracted from the brown macroalgae $C$. nodicaulis, $C$. usneoides and F. spiralis against different pathogenic yeast and fungi. Antifungal activity against all the studied species was observed, with the yeast C. albicans ATCC 10231 being the most susceptible, while the most susceptible fungi were E. floccosum and T. rubrum. The action mechanisms of phlorotannins were also evaluated. In the case of phlorotannins of $C$. nodicalus and C. usneoides, the results indicated a lower ergosterol content in the cell membrane of the yeast and fungi, respectively, which disrupted cellular integrity and functions. On the other hand, F. spiralis phlorotannins reduced the chitin content of the fungi cell wall, an essential wall component. Furthermore, they inhibited the formation of the germ tube of C. albicans, reducing its virulence and its capacity to adhere to epithelial cells. Finally, all phlorotannins increased the activity of the mitochondrial respiratory rate, which may increase the production of reactive oxygen species [134]. Phlorotannins also present antiviral activity. Five phlorotannins extracted from the brown algae E. clava displayed inhibitory effects against the Influenza A virus, through the inhibition of the neuraminidase, a critical enzyme for the life cycle of the virus [135]. Polyphenolic rich extracts from E. arborea and S. filiformis have demonstrated antiviral effects against Measles virus. Authors have proposed that polyphenols act by direct inactivation of the viral particle, which prevents the infection of cells [136].

Finally, in the case of pigments, the antimicrobial mechanism has not been fully understood. The most studied pigments are the carotenoids, which are supposed to act trough the accumulation of lysozyme, an enzyme able to digest bacterial cell walls [20]. Among carotenoids, fucoxanthin stands out and its antimicrobial properties have been tested against different pathogenic bacteria [34]. Recently, this compound has been tested against E. coli, B. cereus, B. subtilis, K. pneumoniae, S. aureus, P. aeruginosa and $L$ monocytogenes. The proposed mechanisms consist of an increase in permeability, leakage of the cytoplasm and inhibition of nucleic acid formation [128]. Regarding antifungal activity of pigments, chlorophyll extracts from S. pallidum was tested against fungi S. glycines and A. niger and shown to possess low antifungal activity. However, the action mechanism has not been elucidated [150].

\section{Novel Liquid-Liquid and Solid-Liquid Extraction Technologies to Efficiently Extract Algal Bioactive Compounds}

Over the years, significant research efforts have been made to efficiently extract algae bioactive compounds by applying different methodologies. Conventional extraction methods (solid-liquid extraction) have numerous limitations, e.g., lower efficacy, high energy cost and low yield, thus new state-of-the-art extraction methodologies are required. Table 3 presents several articles in respect of the antimicrobial activity of macroalgae crude extracts, using the technologies mentioned below. 
Table 3. Antimicrobial activity of macroalgae crude extracts obtained using emerging extraction technologies.




Table 3. Cont.

\begin{tabular}{|c|c|c|c|c|c|}
\hline Method & Conditions & Macroalgae & $\begin{array}{l}\text { Bioactive } \\
\text { Compound }\end{array}$ & Main Outcomes & Ref. \\
\hline \multirow{3}{*}{ PLE } & $\begin{array}{l}\mathrm{Hx}, \mathrm{EtOAc}, \mathrm{AcO}, \\
\mathrm{EtOH}, \mathrm{EtOH}: \mathrm{H}_{2} \mathrm{O} \\
(50: 50)\end{array}$ & $\begin{array}{l}\text { U. intestinalis, } \\
\text { U. lactuca, F. } \\
\text { vesiculosus, D. } \\
\text { dichotoma, } C \text {. } \\
\text { baccata, } H . \\
\text { elongata }\end{array}$ & Fatty acids & $\begin{array}{c}\text { F. vesiculosus extract } \\
\text { exhibited the best } \\
\text { antimicrobial properties }\end{array}$ & [157] \\
\hline & $\begin{array}{c}\mathrm{Hx}, \mathrm{EtOH}, \mathrm{W} ; 200^{\circ} \mathrm{C}, \\
20 \mathrm{~min}\end{array}$ & H. elongata & $\begin{array}{c}\text { Fatty } \\
\text { acids/pigments }\end{array}$ & $\begin{array}{l}\text { All extracts presented } \\
\text { antimicrobial activity } \\
\text { against } S . \text { aureus, E. coli, } \\
\text { C. albicans and } A \text {. niger }\end{array}$ & [158] \\
\hline & $\begin{array}{l}\mathrm{H}_{2} \mathrm{O}, \mathrm{MeOH}, \mathrm{DCM} \\
\text { Temperature }(20,40, \\
\left.60^{\circ} \mathrm{C}\right)\end{array}$ & F. vesiculosus & $\begin{array}{l}\text { Phlorotannins/ } \\
\text { phosphatidylcholine/ } \\
\text { betaine/lipids/ } \\
\text { chlorophylls/ } \\
\text { carotenoids }\end{array}$ & $\begin{array}{l}\text { F. vesiculos extract was } \\
\text { only effective as an } \\
\text { antimicrobial agent to } \\
\text { MRSA }\end{array}$ & [159] \\
\hline
\end{tabular}

Conditions: Acetone (AcO), Ethanol (EtOH), Methanol (MeOH); Dichloromethane (DCM), Water $\left(\mathrm{H}_{2} \mathrm{O}\right)$, Hexane (Hex), Ethyl acetatete (EtOAc). n.d: not described. Methods: Supercritical fluid extraction (SFE), Ultrasound Assisted Extraction (UAE), Microwave-assisted extraction (MAE), Ultrasonic-Microwave Assisted Extraction (UMAE), Enzymatic-Assisted Extraction (EAE), Enzymatic-Ultrasound Assisted Extraction (EUAE), Subcritical Water Extraction (SWE), Subcritical Water Hydrolysate (SWH), Pressurized Liquid Extraction (PLE).

\subsection{Supercritical Fluid Extraction (SFE)}

Supercritical fluid extraction (SFE) is a green analytical methodology used for the extraction of high-value bioactive compounds from complex matrixes [160]. SFE uses supercritical fluids, which above their critical point exhibit liquid-like characteristics such as solvent power, and negligible surface tension, as well as gas-like features such as enhanced transport properties.

Comparing SFE with other conventional extraction techniques, SFE presents several advantages, namely the use of minimal solvents, great extraction selectivity, short processing time, and a low degradability of the extract, showing a broad application for different bioactive compounds [161].

The thermodynamics properties of carbon dioxide $\left(\mathrm{CO}_{2}\right)$ make it the preferred solvent for SFE-based extraction processes [151]. Moreover, due to its low toxicity, low cost, low explosivity, facile availability and environmentally friendly nature, it also presents major factors favoring the choice of $\mathrm{CO}_{2}$ as the SFE solvent [162]. Considering the physical characteristics, $\mathrm{CO}_{2}$ can only be used as the extraction solvent for the extraction of nonpolar or low polarity compounds (as supercritical $\mathrm{CO}_{2}$ is a nonpolar solvent). Nevertheless, the polarity of $\mathrm{CO}_{2}$ can be modulated using co-solvents such as small amounts of ethanol or methanol, increasing the extraction yields of polar compounds [162]. Recently, several reports described the application of SFE to extract high value bioactive molecules in arctic brown algae of the species $F$. vesiculosus. The arctic brown fraction extracts present a predominant content of fatty acids [151,163], polyphenols [163,164], carotenoids and chlorophylls [164]. Moreover, these artic brown algae SFE extracts also possess pronounced bacterial, fungicidal and immunostimulant activities [163].

Despite the potential of the SFE technique and its suitability to extract high-value bioactive compounds from algae, clearly the extraction depends on the nature of the target compounds. Using the SFE technique, a study concluded that $D$. salina extracts in the presence of SFE at 314 bar and $9.8^{\circ} \mathrm{C}$ showed a substantial antimicrobial activity against E. coli, S. aureus, C. albicans and A. niger. As indicated in the work, this notable antimicrobial activity could be attributed to the presence of indolic compounds, PUFAs, and carotene metabolism, such as $\beta$-ionone and neophytadiene in the SFE D. salina extracts [151].

The antifungal potential of the brown algal F. vesiculosus was studied. To perform this study, algal extracts were obtained using SFE at a temperature of $50{ }^{\circ} \mathrm{C}$ and a pressure of 300 bar. Using aqueous algal extracts at the concentrations of $0.5 \%$ and $1.0 \%$, a $100 \%$ growth inhibition of macroconidia within 
$144 \mathrm{~h}$ was obtained. Moreover, F. vesiculosus SFE extracts also promoted a $48 \%$ and $72 \%$ mycelial growth of phytopathogenic F. oxysporum and F. culmorum, respectively, after $168 \mathrm{~h}$ of incubation [152].

\subsection{Ultrasound Assisted Extraction (UAE)}

Ultrasound assisted extraction (UAE) technique uses acoustic waves in the kilohertz range $(20 \mathrm{kHz}$ to $100 \mathrm{kHz}$ ) that travel through the solvent producing cavitation bubbles. When the cavitation bubbles burst at the surface of the complex sample matrix, a shockwave induces damage to the sample cell wall enhancing the mass transfer of high-value bioactive compounds across cellular membranes into the solution [165]. Two different types of equipment can be used to carry out UAE: the ultrasonic bath (indirect sonication) that operates at a frequency between $40-50 \mathrm{kHz}$ using a power of $50-500 \mathrm{~W}$ and the ultrasonic probe which operates only at $20 \mathrm{kHz}$. The principal difference between this equipment is the way that the ultrasound wave affects the sample [166].

The UAE technique is considered a cold extraction technique, as temperature during the extraction process is comparatively low and does not affect the stability of extracted compounds. UAE presents several advantages, such as the potential to reduce or eliminate the use of toxic chemical solvents and it is a more economic process (no need of supplementary energy to separate phases and to eliminate solvent). Moreover, using UAE, full extractions can be completed in a few minutes with high reproducibility, simplifying the manipulation and work-up, giving a higher purity to the final product and eliminating post-treatment of water waste [167].

UAE was the method of choice to extract bioactive compounds (total phenolics, fucose and uronic acid) from $A$. nodosum. To investigate the effect of process variables (extraction time, acid concentration, ultrasonic amplitude) response surface methodology (RSM) was employed. Higher extraction yields were obtained for total phenolics, fucose and uronic acid, respectively, at optimized extraction conditions of $25 \mathrm{~min} 0.03 \mathrm{M} \mathrm{HCl}$ and $114 \mu \mathrm{m}$ of ultrasonic amplitude. Furthermore, it was demonstrated that UAE can be used to enhance the extraction of bioactive compounds from seaweed [168].

The extraction of phenolic compounds including gallic acid, catechins and their galloylated esters (gallates) in red and brown edible seaweeds, Palmaria sp., Porphyra sp., H.elongata, L. ochroleuca and U. pinnatifida, was carried out using ultrasonic bath, magnetic stirring and water bath with constant shaking [169].

UAE was also used to extract polysaccharides (fucose and glucans) from L. digitata [170] and L. obtuse [171]. In this case, the RSM was used to investigate the effect of the UAE variables (temperature, time and ultrasonic amplitude) on the macroalgal extracts to enhance the yields of polysaccharides and its antioxidant activities. A study observed that the UAE studied parameters showed significant influence on the levels of fucose. The highest fucose levels were obtained at optimized conditions of $76^{\circ} \mathrm{C}$ during $10 \mathrm{~min}$ and ultrasonic amplitude of $100 \%$ using $0.1 \mathrm{M} \mathrm{HCl}$ as solvent [170]. While, the optimum UAE extraction parameters for the maximum phenolic content in L. obtusa extracts were a solvent seaweed ratio of 30:1; extraction temperature of $50{ }^{\circ} \mathrm{C}$ and extraction time of $42.8 \mathrm{~min}$ [171].

The same experimental design approach was used to compare UAE and microwave-assisted extraction (MAE), where the combination of both methodologies generated higher yields of compound extraction when compared to the use of UAE and MAE methods separately [172].

\subsection{Microwave Assisted Extraction (MAE)}

Microwave-assisted extraction (MAE) is one of the most advanced techniques used for the extraction of bioactive compounds from numerous seaweeds $[173,174]$. Microwaves are a nonionizing radiation with wavelengths ranging from as short as $1 \mathrm{~mm}$ to as long as $1 \mathrm{~m}$ and frequencies between $300 \mathrm{MHz}$ and $300 \mathrm{GHz}$. Microwaves induce molecular motion in materials and solvents with dipoles, leading to subsequent heating of the sample. This heating leads plant cells to lose their moisture content through evaporation; the steam produced swells and ultimately ruptures the cells, releasing their bioactive components more easily. MAE of bioactive compounds might be affected by numerous 
factors, such as the frequency, power, time of extraction, moisture content and particle size of the sample, type and concentration of the solvent, ratio of solid to liquid, extraction temperature, extraction pressure, and number of extraction cycles [174,175].

Carrageenans from S. chordalis (Rhodophyceae,) harvested from the Brittany coast (France) were successfully extracted by MAE methodology. Native carrageenan extracted by MAE had the highest yield $(29.3 \%)$ after $10 \mathrm{~min}$ at $90^{\circ} \mathrm{C}$. Evaluation of the antiviral activity of $S$. chordalis carrageenan against HSV-1 (Herpes simplex virus type one) showed a $\mathrm{EC}_{50}$ of the iota-carrageenans fractions in the range of 3.2 to $54.4 \mu \mathrm{g} / \mathrm{mL}$ (MOI $0.01 \mathrm{ID} \mathrm{5}_{5} / \mathrm{mL}$ ) with no cytotoxicity in that range of concentrations [176].

Microwave-assisted aqueous two-phase extraction was utilized for simultaneous extraction and separation of polysaccharides from S. pallidum. Using the optimal extraction conditions of $21 \%$ ethanol $(\mathrm{w} / \mathrm{w})$ and $22 \%$ ammonium sulfate $(\mathrm{w} / \mathrm{w})$, ratio of material to liquid 1:60 $(\mathrm{g} / \mathrm{mL})$, extraction time of $15 \mathrm{~min}$, microwave power of $830 \mathrm{~W}$, and extraction temperature $95^{\circ} \mathrm{C}$, an aqueous extracts rich in fucose, galactose, mannose, and glucuronic acid was obtained [177]. This approach demonstrated to be a high-efficient and practical method for the bioactive compounds extraction from seaweeds [178]. Others seaweeds such as S. thunbergii, and red algae P. haitanensis [179]; G. lemaneiformis [180]; U. pertusa [181]; S. ceylonensis, U. lactuca, G. lemaneiformis and Durvillaea antarctica, [180] were also subject to MAE to obtain polysaccharides. Shuntaro Tsubaki et al. [182] proved the efficacy of microwave-assisted hydrothermal extraction for the production of sulfated polysaccharides from $U$. meridionalis, U. ohnoi and M. latissimum [182].

Four seaweed species: A. nodosum, L. japonica, L. trabeculata and L. nigrecens were investigated for phenolic compounds extraction and their antioxidant capacity was also evaluated by MAE. These extracts presented a higher crude yield and higher total phenolic content when compared to conventional extraction techniques. MAE was also employed for the antioxidant extraction from green algae Chaetomorpha sp. [183]. Alternative microwave-assisted configurations such as microwave hydrodiffusion and gravity (MHG), were also used for the extraction of phenolic compounds in L. ochroleuca a brown seaweed [184].

Phlorotannin was obtained from C. flexuosum, C. plumosum and E. radiata by MAE. Using water as extraction solvent a most efficient extraction process with shorter processing times and a higher purity product was obtained [185]. The same compounds were also attained from the brown seaweed C. sedoides [186].

Pigments like fucoxanthin, were also recovered by MAE from L. japonica, U. pinnatifida and S. fusiforme [187]. MAE under optimum extraction conditions was an effective method to recover fucoidan from F. vesiculosus. [188] and from E. radiata [189].

Fucoidans from brown alga $N$. zanardinii [153] were isolated using conventional and non-conventional extraction procedures (subcritical water extraction, UAE and MAE), in order to evaluate the effects of the recent introduced technologies on the biochemical characteristics and saccharide composition of the extracts, along with their antibacterial, antiviral and cytotoxic properties. The highest and lowest fucoidan yields were obtained by sub critical water extraction and UAE, respectively. It has been reported that the use of different extraction methods resulted in the achievement of fucoidans with various chemical compositions and molecular weights. The algal extracts were tested against E. coli, P. aeruginosa, L. monocytogenes and S. aureus. Fucoidans extracted by $\mathrm{MAE}$ and sub critical water extraction were able to inhibit the growth of $E$. coli. However, fucoidans isolated by EUAE, UAE and MAE showed inhibitory effects against P. aeruginosa [153].

A comparison between hot reflux extraction and MAE was conducted, leading to the conclusion that the amount of polysaccharides achieved by both techniques were similar [190]. Studies using hydrodistillation SFE and focused microwave-assisted hydrodistillation indicated that the highest extraction yield was obtained when SFE was used, even though the bioactive terpenes and fatty acids were obtained in greater quantity by the MAE method. 
In other studies, MAE and UAE methodologies were shown to be the more efficient techniques for the chlorophyll and carotenoid isolation from freshwater green algae: C. glomerata, C. rivularis and U. flexuosa compared to the Soxhlet extraction and solid phase extraction [191].

The algal contents of Oedogonium sp., Stigeoclonium sp., Ulothrix sp. and Nitzschia sp. were extracted by MAE, using methanol an ethanol as extracting agents. The obtained crude extracts were tested against E. coli, S. aureus and S. typhi. All the four algal species inhibited Gram-positive and Gram-negative bacteria, except $S$. aureus which was resistant to the algal extracts. Only the ethanolic extracts of Nitzschia sp. and Ulothrix sp. showed antibacterial activity against this strain [154].

\subsection{Enzymatic-Assisted Extractions (EAE)}

Enzymatic-assisted extraction (EAE) is based on the innate ability that enzymes have to catalyze reactions with a high specificity, selectivity and an ability to function under mild processing conditions in aqueous solutions [192], the EAE of bioactive compounds from numerous sources, including marine ones, has received much attention in recent years. As compared to other reported conventional extraction methods, EAE offers some noteworthy advantages namely, high selectivity, overall efficacy, rapid extraction, eco-friendly procedures, low-energy consumption, minimal usage of harsh chemicals and process recyclability [160]. A range of enzymes including ligninolytic, cellulolytic and proteolytic enzymes has been extensively used as EAE catalysts. Enzyme-based pre-treatment or catalysis easily causes the breakdown and/or hydrolysis of complex materials on the cell walls and membranes, thus also supporting the recovery of intracellular bioactive constituents which are not easily extractable through conventional extraction methods [193].

A study used an EAE coupled with UAE to achieve the eco-friendly extraction of soluble bioactive fractions from the macroalga S. muticum. Using a mixture of commercial complex enzyme formulations, these authors obtained an S. muticum extract rich in bioactive components such as carbohydrates, monosaccharides, oligosacaccharides and polyphenols [194]. A similar strategy was used by other authors [195] to extract bioactive compounds from green and brown seaweed C. tomentosum, S. muticum and O. pinnatifida. Extracts obtained from those seaweeds were evaluated for proximate characterization and biological properties. According to the authors, high extraction yields of cellulase, viscozyme, nitrogen, total phenolics and sugars and sulfated polysaccharide were measured.

EAE was used (using five carbohydrases and three proteases) to extract multiple bioactive compounds such as polyphenols, proteins and polysaccharides from several seaweeds, namely S. boveanum, S. angustifolium, P. gymnospora, C. cervicornis, C. sinuosa, I. stellata and F. irregularis [155]. Several fractions of the seaweed extracts were used against $S$. aureus, E. faecalis, S. cerevisiae, B. cereus and A. hydrophila. Although antimicrobial activities of the enzymatic extracts were low, flavourzyme resulted in a higher number of seaweed extracts with antimicrobial activity against foodborne pathogens [155].

\subsection{Accelerated Solvent Extraction (ASE)}

Accelerated solvent extraction (ASE) also referred as pressurized liquid extraction (PLE) is deemed an excellent technique for the extraction of polar compounds [196,197]. ASE is a solid-liquid extraction process performed at high temperatures $\left(50-200^{\circ} \mathrm{C}\right)$ and high pressures (10-15 MPa). Its main advantages over traditional extraction methods are the dramatic decrease in the amount of solvent used and extraction time [198].

A recent study used ASE to extract phenolic contents (using water, ethanol:water and acetone:water as extraction solvents) from algae A. nodosum, P. canaliculata, F. spiralis and U. intestinalis [199]. This paper compared ASE with the conventional solid-liquid extraction technique. It was observed that ASE was more effective for the extraction of polyphenols when acetone:water (80:20) was used as solvent. However, the traditional solid-liquid extraction (using ethanol:water (80:20) or 100\% of water) resulted in higher phenolic content in brown macroalgal extracts. 
Another experiment used ethyl acetate and water by ASE to extract bioactive compounds from P. pavonica seaweed. High-performance thin-layer chromatography was used to analyze the ethyl acetate and water ASE P. pavonica extracts. Chromatograms indicated that several families of compounds (terpenes, flavonoids and amino acids) were extracted from the studied seaweed but only the ethyl acetate extracts contained polyphenols and lipids [200].

In another case, the antimicrobial activity of H. elongata ASE extracts was assessed. In this work, the use of several solvents (ethanol, hexane, and water) demonstrated that ASE technology was able to extract a variety of bioactive molecules namely, fatty acids, tocopherols, alkanes and phenols from H. elongata. The highest yield was reached when only water was used as the extraction solvent. Additionally, the antibiotic and antifungal activity were also tested in S. aureus, E. coli and fungus C. albicans and A. niger. In this case, the best results were obtained when ethanol was used as the ASE solvent [158].

ASE was also used to extract several bioactive compounds such as phlorotannins, phosphatidylcholine, betaine lipids, chlorophylls and carotenoids from the algae S. muticum [201,202]. A study used a combination of ASE and water extraction to withdrawal molecules of interest from seaweeds. Furthermore, those authors [159] also tested the antimicrobial activity of F. vesiculosus extracts against E. faecium, MRSA, K. pneumoniae, A. baumannii, P. aeruginosa, E. coli, C. albicans, C. neoformans, V. anguillarum, P. bacteriolytica and P. elyakovii. Although F. vesiculosus extracts produced evident MRSA growth inhibition, radical scavenging and pro-apoptotic activities, this study highlighted the significant effect of seasonal sampling on these activities [159].

\subsection{Intensity Pulsed Electric Fields (IPEF)}

In intensity pulsed electric fields (IPEF), the complex biological samples are placed between two electrodes hosted in a treatment chamber and exposed to high intensity electric fields $(10-50 \mathrm{kV} / \mathrm{cm})$, applied in the form of repetitive pulses of very short duration (from several nanoseconds to a few milliseconds), inducing the permeabilization of the cell membranes by electroporation, easing the subsequent release of intracellular matter as demonstrated in a recent study with microalgae [203,204]. The advantages of IPEF are short treatment time, low treatment temperature, increase in shelf life, increased extractive yield, use of both batch and continuous processes and improved metabolite extraction [203].

Polikovsky and co-workers [205] investigated a new technology to process macroalgae into biorefinery, employing efficient energy and zero waste conversion of macroalgae biomass into food, chemicals and fuels. For this purpose, a selective extraction of proteins from Ulva genus green macroalgae was carried out using an IPEF process. Using 75 pulses with an average electric field strength of $3 \mathrm{kV} / \mathrm{cm}$ and pulse duration of $6 \mu \mathrm{s}$, several proteins were extracted from the Ulva genus, namely, calreticulin, ferredoxin-NADP ${ }^{+}$reductase, fructose-1,6-bisphosphatase, fructose-bisphosphate aldolase 1, phosphoglycerate kinase and ribosomal protein L12 (chloroplast). Polikovsky demonstrated that IPEF process, despite some proteins were partially or completely degraded by the pulse electric field treatment, this method is selective and efficient [205].

\section{Applications}

\subsection{Food Industry and Animal Feed}

Nowadays, it has been demonstrated that synthetic antimicrobials, like sodium benzoate, sodium nitrite or sorbic acid, used in the food industry, can produce negative effects on the consumer's health. Thus, the search for new antimicrobials, obtained from natural sources is gaining importance [206]. Different studies have reported the inhibitory effects of macroalgae compounds against food-borne pathogens such as E. coli, L. monocytogenes, S. aureus or Salmonella sp. Antimicrobials could be included in both the food products as novel functional ingredients, or in the packaging material [207]. In the first case, antimicrobials could be added to the food directly to prevent the spoilage due to the growth 
of microorganisms. Recently, the polysaccharide fucoidan extracted from F. vesiculosus showed in vitro inhibitory effects against L. monocytogenes and S. enterica serovar Typhimurium. Furthermore, this compound was included in the formulation of a functional apple beverage. The results showed that fucoidan was significantly effective in preventing the spoilage produced by the mentioned pathogens [208]. On the other hand, antibacterial compounds isolated from macroalgae could be used in the active packaging sector, which faces the same spoilage produced by microorganisms. Studies in this area have been focused on the incorporation of antimicrobial compounds into the packaging material to eliminate or reduce the growth of pathogens, extending the shelf life of the products. Currently, several edible films contain alginates and carrageenans to prevent microbial spoilage. For example, carrageenan and chitosan containing films demonstrated inhibitory effects against $C$. jejuni and lactic acid bacteria in raw chicken breast. Biodegradable films containing F. spiralis extract and sorbic acid have been developed to enhance the shelf life of food products [34].

Regarding animal feed, antimicrobial compounds like laminarin and fucoidan could be used in the animal feeding to substitute commercial antibiotics (which may cause negative effects both on animals treated and environment), enhance the animal survival and also the safety and nutritional characteristics of animal products consumed by humans [209]. For example, the administration of fucoidan to monogastric animals inhibited the attachment of bacterial species in the gut and also obstructed the binding of Enterococci and Streptococci sp. to the extracellular matrix, preventing the colonization of the mucosa [209]. Likewise, fucoidan and other antimicrobial compounds are useful tools in aquaculture, which can increase the resistance of the aquatic species against bacterial and viral diseases. For instance, dietary supplementation with fucoidan, alginate and ulvan have demonstrated the ability to improve the survival of several fish and crustaceans species against bacteria and viruses that threaten aquaculture production [210].

\subsection{Cosmetics and Pharmaceuticals}

Considering the large amount of studies that have demonstrated that some compounds in macroalgae might have antimicrobial capabilities, there is a possibility that these compounds may be used in the development of treatments against pathogens and diseases. In Table 4, some examples of the antimicrobial properties against bacteria, antibiotic-resistant bacteria, fungi and viruses have been shown. For example, polyphenols could be used in dental products for the treatment of chronic periodontitis [132], nail treatments to eliminate fungi [134] or in the development of new antivirals [135,136], among other interesting applications. Polysaccharides have shown antimicrobial effects against bacteria and fungi, but their antiviral properties are gaining attention in the pharmaceutical sector [132]. In the case of other compounds, like proteins and pigments, their antimicrobial properties have not yet been widely studied and understood, so their current pharmaceutical applications are limited. Regarding cosmetic applications, several macroalgal compounds could be interesting to develop safe treatments against acne. A $\beta$-D-galactosyl O-linked glycolipid has been identified as the main compound responsible of the inhibitory effects of the ethyl acetate extract of $F$. evanescens against $C$. acnes. This bacterium can colonize the skin and is related with acne. Finally, the phenolic compound fucofuroeckol-A, isolated from methanolic extract of E. bicyclis also showed antimicrobial properties against the mentioned microorganism [33]. Nevertheless, most of antimicrobial studies are in vitro and thus, to ensure the efficacy and safety of these compounds, further in vivo studies are required. 
Table 4. Macroalgae-based nanoparticles (NPs) with antimicrobial properties.

\begin{tabular}{|c|c|c|c|c|}
\hline Macroalgae & NPs & Size (nm) & Antimicrobial Activity & Ref. \\
\hline S. muticum & $\mathrm{Ag}$ & $43-79$ & $\begin{array}{c}\text { Growth inhibition of } B . \\
\text { subtilis, K. pneumoniae and } S \text {. } \\
\text { typhi }\end{array}$ & [211] \\
\hline G. amansii & $\mathrm{Ag}$ & $27-54$ & $\begin{array}{l}\text { Antifouling activity against } \\
\text { P. aeruginosa, } \\
\text { V. parahaemolyticus, E. coli, A. } \\
\text { hydrophila, B. pumilus and } \\
\text { S. aureus }\end{array}$ & [212] \\
\hline G. corneum & $\mathrm{Ag}$ & $20-50$ & $\begin{array}{l}\text { Antimicrobial and } \\
\text { antibiofilm activity against } \\
\text { C. albicans and E. coli }\end{array}$ & [22] \\
\hline G. corticata & $\mathrm{Ag}$ & $18-46$ & $\begin{array}{c}\text { Antifungal activity against } \\
\text { Candida spp. }\end{array}$ & [213] \\
\hline G. birdiae & $\mathrm{Ag}$ & $20-95$ & $\begin{array}{c}\text { Antimicrobial activity } \\
\text { against } E \text {. coli }\end{array}$ & [214] \\
\hline S. wightii & $\mathrm{Ag}$ & $55-70$ & $\begin{array}{c}\text { Maximum growth inhibition } \\
\text { against } M . \text { luteus }>S . \\
\text { marcescens }\end{array}$ & [215] \\
\hline V. pachynema & $\mathrm{Ag}$ & $30-40$ & $\begin{array}{c}\text { Moderate growth inhibition } \\
\text { against } M . \text { luteus }>S \text {. } \\
\text { marcescens }\end{array}$ & [215] \\
\hline P. hornemannii & $\mathrm{Ag}$ & $70-75$ & $\begin{array}{c}\text { Antimicrobial activity } \\
\text { against the fish pathogens: } \\
V . \text { parahaemolyticus, } V . \\
\text { vulnificus, } V \text {. harveyii and } V \text {. } \\
\text { anguillarum }\end{array}$ & [216] \\
\hline U. faciata & $\mathrm{Ag}$ & 7 & $\begin{array}{l}\text { Bacterial reduction in textile } \\
\text { fabrics against } S \text {. aureus and } \\
\text { E. coli }\end{array}$ & [217] \\
\hline P. capillacea & $\mathrm{Ag}$ & 7 & $\begin{array}{l}\text { Bacterial reduction in textile } \\
\text { fabrics against } S \text {. aureus and } \\
\text { E. coli }\end{array}$ & [217] \\
\hline J. rubens & $\mathrm{Ag}$ & 12 & $\begin{array}{l}\text { Bacterial reduction in textile } \\
\text { fabrics against } S \text {. aureus and } \\
\text { E. coli }\end{array}$ & [217] \\
\hline C. $\operatorname{sinusa}$ & $\mathrm{Ag}$ & 20 & $\begin{array}{l}\text { Bacterial reduction in textile } \\
\text { fabrics against } S \text {. aureus and } \\
\text { E. coli }\end{array}$ & [217] \\
\hline S. plagiophyllum & $\mathrm{AgCl}$ & $18-42$ & $\begin{array}{l}\text { Growth inhibition of E.a coli } \\
\text { Growth inhibition of } P \text {. } \\
\text { aeruginosa, K. oxytoca, } E \text {. }\end{array}$ & [218] \\
\hline S. marginatum & $\mathrm{Au}$ & $18-94$ & $\begin{array}{c}\text { faecalis, K. pneumoniae, } \\
\text { V. parahaemolyticus, V. } \\
\text { cholerae, S. typhi, S. paratyphi, } \\
\text { and P. vulgaris }\end{array}$ & [219] \\
\hline S. plagiophyllum & $\mathrm{Au}$ & $65-66$ & $\begin{array}{c}\text { Antibacterial activity against } \\
S . \text { typhi and E. coli by } \\
\text { bacteria membrane lysis }\end{array}$ & [220] \\
\hline C. sinuosa & $\mathrm{Fe}_{3} \mathrm{O}_{4}$ & $11-34$ & $\begin{array}{l}\text { Excellent antifungal activity } \\
\text { against } A \text {. flavus and } F \text {. } \\
\text { oxysporum. Antibacterial } \\
\text { activity against } E \text {. coli, } P \text {. } \\
\text { aeruginosa, S. typhi, V. cholera, } \\
\text { B. subtilis and } S \text {. aureus }\end{array}$ & [221] \\
\hline
\end{tabular}


Table 4. Cont.

\begin{tabular}{|c|c|c|c|c|}
\hline Macroalgae & NPs & Size $(\mathrm{nm})$ & Antimicrobial Activity & Ref. \\
\hline P. capillacea & $\mathrm{Fe}_{3} \mathrm{O}_{4}$ & $16-23$ & $\begin{array}{c}\text { Antibacterial activity against } \\
\text { E. coli, P. aeruginosa, S. typhi, } \\
\text { V. cholera, B. subtilis and } \\
\text { S. aureus }\end{array}$ & [221] \\
\hline U. flexuosa & $\mathrm{Fe}_{3} \mathrm{O}_{4}$ & 12 & $\begin{array}{l}\text { Antibacterial activity against } \\
\text { B. subtilis, S. aureus, E. coli, E. } \\
\text { faecalis and S.s epidermidis }\end{array}$ & [222] \\
\hline S. wightii & $\mathrm{ZrO}_{2}$ & 4.8 & $\begin{array}{l}\text { Enhancement of the } \\
\text { antibacterial activity against } \\
\text { B. subtilis, E. coli and S. typhi }\end{array}$ & [223] \\
\hline S. wightii & $\mathrm{MgO}$ & 68 & $\begin{array}{c}\text { Antibacterial activity against } \\
\text { S. pneumonia, MRSA } 11, \\
\text { MRSA 56, E. coli, } P . \\
\text { aeruginosa and } A \text {. baumannii }\end{array}$ & [224] \\
\hline S. myriocystum & $\mathrm{ZnO}$ & $76-186$ & $\begin{array}{l}\text { Growth inhibition against } \\
\text { Gram }(+) \text { bacteria: S. mutans } \\
>\text { M. luteus and Gram (-): } \\
\text { Neisseria gonorrohea }>V \text {. } \\
\text { cholera }>\text { K. pneumonia. } \\
\text { Antifungal activity against } \\
\text { C. albicans }>\text { A. niger }\end{array}$ & [225] \\
\hline
\end{tabular}

\subsection{Anti-Fouling}

Surfaces immersed in the marine environment could be colonized by biofouling organisms, such as bacteria, protist or invertebrates [226]. Several paints containing toxic compounds like tributyltin, mercury or arsenic have been designed to eliminate these communities. However, these paints contribute to marine contamination, affecting the food chain and producing genetic mutations [227]. Therefore, the development of alternative solutions is of great importance. Antimicrobial compounds from macroalgae could be used for this purpose [33]. Although most of studies have tested different extracts, some of them have identified the compounds involved in the antifouling properties [226]. Several of these compounds have been identified in green, brown and red macroalgae such as pigments, polyphenols or fatty acids. For example, polyphenolic compounds from the green algae $U$. pertusa showed anti-algal properties against red tide microalgae [228]. Phlorotannins from Sargassum sp. are allelochemicals, which several studies have demonstrated to be exuded by the macroalgae into the surrounding water to prevent the settlement of epiphytes in their surface [229]. Finally, some antifouling compounds have been identified in the red algae L. translucida, mainly fatty acid derivatives [230]. In the following years, an increase in the identification of compounds with antifouling activities is expected, as well as the development of their biotechnological applications.

Other interesting approach to obtain anti-fouling products is the inhibition of the quorum sensing of bacteria, defined as a cell-to-cell communication system, based on the production, release of and perception of molecules by the bacterial cells. These molecules are involved in a great variety of processes, including biofilm formation [227]. Several extracts and compounds derived from macroalga with the ability to inhibit quorum sensing have been reported. For example, Carvalho et al. (2017) [231], reported that $C$. cervicornis extracts inhibited the growth of $C$. violaceum, due to the inhibition of the quorum sensing, since no killing effect was observed. A study conducted with P. gymnospora demonstrated that the alpha-bisabolol obtained from this alga inhibited significantly the quorum sensing and biofilm formation of $S$. marcescens [232]. Recently, several new $\alpha$-pyridones, derived from E. prolifera have been identified. The results of the gar diffusion method showed that four of these compounds significantly inhibited the expression of genes involved in the quorum sensing in P. aeruginosa [233]. Further research on macroalgal extracts and compounds could be promising to develop new applications, as a strategy to reduce the use of antimicrobials [232]. 


\section{New Approaches and Future Perspectives}

In the previous sections and throughout the manuscript a series of applications of the antimicrobial compounds obtained from algae is given. Among all these applications, the most common is the use of these molecules or extracts as preservatives of natural origin in the food, cosmetic or pharmaceutical industry. Namely, in the food industry new trends are rapidly being incorporated to the market such as active packaging or the use of antibiofilm compounds [14,34]. Additionally, research on natural antimicrobials has also increased due to the current problem related to resistant strains. In this regard, polyphenols represent molecules widely employed by in vitro studies for their synergistic effect when acting with other conventional antimicrobials and thus, resulting in a higher efficacy, lower doses and side-effects reduction [234]. However, to our knowledge, few studies have assessed the in vivo properties of polyphenols or other enriched extracts obtained from algae.

On the other hand, nanoparticles (NPs) and nanomaterials have recently gained popularity both in engineering and medical sciences. Algae have been proposed as alternative nanobiofactories for the synthesis of NPs since physicochemical synthesis is usually difficult and expensive. Algae can facilitate metal reduction as they can accumulate metal ions and stabilize and remodel them. Likewise, algae extracts are known for their biological properties and particularly, they have been studied for their antibacterial and antifungal effects [235]. Their mechanism of action consists basically of the NPs adhesion to the microorganism surface and their penetration into cells. Once there, different interactions can occur with the bacterial components: disruption of the enzymatic activity or the production of reactive oxygen species (ROS) that can result in mitochondrial, protein or DNA damage [236]. The use of algae in NPs synthesis is quite a new trend and therefore, different authors have performed studies on characterizing, synthetizing and researching their antimicrobial potential. Table 4 shows a series of examples of algae-based NPs and their antimicrobial activity. For instance, a study found that silver NPs based on four different algae (U. faciata, P. capillacae, J. rubens and C. sinusa) could reduce the bacterial growth of $S$. aureus and E. coli on textile cotton fabrics. This capacity could be useful for the design of antiseptic dressings with biomedical applications [217]. In another case, also Ag-based NPs obtained from the red algae G. amansii, showed potential as antifouling for their antimicrobial activity against different microorganisms [212]. Among all the examples given on Table 4, the majority of the studies have been carried out on silver-NPs, however other approaches are being investigated too and their antimicrobial activity has been proved against plenty of microorganisms. Moreover, other approaches apart from antimicrobial or antifouling applications have been proposed, such as their use in bioremediation [237]. On the other hand, the use of algae extracts as prebiotics has also been studied. Marine algae have been pointed out as a source of oligosaccharides and polysaccharides and even though these compounds possess several bioactivities, their use as prebiotics is rising because of their high content of dietary fiber, enhancing the growth of those beneficial bacteria in the intestinal tract $[11,238]$.

Taken together, all the information given in the different manuscript sections and considering the favorable consumer perception about these products, there is a huge potential antimicrobials, extracted from algae, to be incorporated into different applications. Future perspectives should focus on the development of further in vivo and toxicological studies and in the transformation of the whole process into a cost-effective and reproducible alternative which goes through the improvement, further study and optimization of the extraction techniques of the bioactive compounds responsible for the antimicrobial activity $[239,240]$.

\section{Conclusions}

The use of bioactive compounds as a constituent in several food-cosmetic- and medical-based products will soon be the norm. Among different sources, macroalgae biomass as a marine by-product has been considered as a promising and viable source of a broader range of bioactive compounds. As evident from this review, algae bio-products include: proteins, peptides, polysaccharides, polyphenols, fatty acids, pigments, and the highest treasure antimicrobial compounds. To obtain these 
valuable bioactive compounds, several innovative green extraction methodologies have been used to efficiently recover them from algae biomass. This review also comprises the recent advancements in the extraction techniques such as supercritical-fluid extraction, accelerated solvent extraction, ultrasound-, microwave-, and enzymatic-assisted extraction. Most of the literature concerning the antimicrobial activity of algae is based on classic extraction techniques. Furthermore, new future approaches should focus on the utilization of natural antimicrobial compounds obtained from algae into the pharmaceutical industry, due to the current problem related to the resistance of the drugs to pathogenic microorganisms. Moreover, algae have been also implicated as a possible alternative for nanoparticles and nanomaterials synthesis, which will raise the possibility to use this by-product in engineering and medical science.

Author Contributions: Formal analysis, M.F.B., M.A.P. and J.S.-G.; Investigation, A.S., S.A.S., M.C., P.G.-O., P.G., M.F.B., M.A.P. and J.S.-G.; Methodology, A.S., S.A.S., M.C., P.G.-O., P.G.; Supervision M.F.B., M.A.P.and J.S.-G.; Validation, M.F.B., M.A.P. and J.S.-G.; Writing-original draft A.S., S.A.S., M.C., P.G.-O., P.G., M.F.B., M.A.P. and J.S.-G.; Writing-review and editing, M.F.B., M.A.P. and J.S.-G. All authors have read and agreed to the published version of the manuscript.

Funding: This research received no external funding.

Acknowledgments: The research leading to these results received financial support from Programa de Cooperación Interreg V-A España-Portugal (POCTEP) 2014-2020 (projects Ref. 0181_NANOEATERS_01_E and Ref. 0377_IBERPHENOL_6_E); from MICINN supporting the Ramón and Cajal grant for M.A. Prieto (RYC-2017-22891); from Xunta de Galicia and University of Vigo supporting the pre-doctoral grant of P. García-Oliveira (ED481A-2019/295); by EcoChestnut Project (Erasmus + KA202) supporting the work of M. Carpena and from postdoctoral support for P. Gullón working under the project Bio Based Industries Joint Undertaking (JU) under grant agreement No 888003 UP4HEALTH Project (H2020-BBI-JTI-2019). This work also received financial support from REQUIMTE/LAQV, National Funds (FCT, Fundação para a Ciência e Tecnologia) through project UID/QUI/50006/2019 and by FEDER-Fundo Europeu de Desenvolvimento Regional funds through the COMPETE 2020-Operational Programme for Competitiveness and Internationalisation (POCI), and by Portuguese funds through FCT-Fundação para a Ciência e a Tecnologia in the framework of the project POCI-01-0145-FEDER-030240_PTDC/OCE-ETA/30240/2017.

Conflicts of Interest: The authors declare no conflict of interest.

\section{Abbreviations}

$\begin{array}{ll}\text { Generic } & \\ \text { ATCC } & \text { American type culture collection } \\ \text { DW } & \text { Dry weight } \\ \text { FW } & \text { Fresh weight } \\ \text { HVS } & \text { Herpes simplex virus } \\ \text { MIC } & \text { Minimal inhibition concentration } \\ \text { MRSA } & \text { Methicillin-resistant Staphylococcus aureus } \\ \text { MOI } & \text { Multiplicity of infection } \\ \text { NPs } & \text { Nanoparticles } \\ \text { RSM } & \text { Response surface methodology } \\ \text { RT } & \text { Room temperature } \\ \text { SARS } & \text { Severe acute respiratory syndrome } \\ \text { UV } & \text { Ultraviolet } \\ \text { Extraction techniques } \\ \text { ASE } & \text { Accelerated solvent extraction } \\ \text { EAE } & \text { Enzyme-assisted extraction } \\ \text { EUAE } & \text { Enzymatic ultrasound assisted extraction } \\ \text { HAE } & \text { Heat-assisted extraction } \\ \text { IPEF } & \text { Intensity pulsed electric fields } \\ \text { MAE } & \text { Microwave-assisted extraction } \\ \text { PLE } & \text { Pressurized liquid extraction } \\ \text { SFE } & \text { Supercritical fluid extraction } \\ \text { UAE } & \text { Ultrasound assisted extraction } \\ \end{array}$




$\begin{array}{ll}\text { Compounds } & \\ \text { DEt } & \text { Diethyl ether } \\ \text { DCM } & \text { Dichloromethane } \\ \text { DPPH } & \text { 1,1-diphenyl-2-picryl hydrazyl } \\ \text { EtOAc } & \text { Ethyl acetate } \\ \text { EtOH } & \text { Ethanol } \\ \mathrm{H}_{2} \mathrm{O} & \text { Water } \\ \mathrm{Hx} & \text { Hexane } \\ \mathrm{MeOH} & \text { Methanol } \\ n \text {-BuOH } & n \text { - Butanol } \\ n \text {-Hx } & n \text {-Hexane } \\ \text { PUFAs } & \text { Poly-unsaturated fatty acids }\end{array}$

Bacteria species

Acinetobacter (A.): A. baumannii. Actinobacillus (A.): A. actinomycetemcomitas. Actinomyces (A.): A. naeslundii, A. odontolyticus. Aeromonas (A.): A. hydrophyla, A. salmonicida. Aspergillus (A.): A. flavus, A. fumigatus, A. niger. Bacillus (B.): B. cereus, B. mycoides, B. pumilus, B. subtilis. Candida (C.): C. albicans, C. dublinensis, C. famata, C. glabrata, C. guilliermondi, C. kefyr, C. krusei, C. membranaefaciens, C. parapsilosis. Campylobacter (C.): C. jejuni. Chromobacterium (C.): C. violaceum. Colletotrichum (C.): C. lindemuthianum. Cryptococcus (C.): C. neoformans. Cultibacterium (C.): C. acnes. Enterobacter (E.): E. aerogens, E. cloacae. Enterococcus (E.): E. faecalis, E. faecium. Epidermophyton (E.): E. flocossum. Erwinia (E.): E. amylovora. Escherichia (E.): E. coli. Fusarium (F.): F. graminearum, F. culmorum, F. oxysporum, F. solani. Fusobacterium (F.): F. nucleatum. Klebsiella (K.): K. oxytoca, K. pneumonia. Lactobacillus (L.): L. brevis. Listeria (L.): L. innocua, L. monocytogenes. Leishmania (L.): L. amazonensis. Macrophomina (M.): M. phaseolina. Methicillin-resistant Staphylococcus aureus (MRSA). Micrococcus (M.): M. luteus. Microsporum (M.): M. canis, M. gypseum. Penicillium (P.): P. verrucosum. Porphyromonas (P.): P. gingivalis. Pseudoalteromonas (P.): P. bacteriolytica. Proteus (P.): P. vulgaris. Pseudomonas (P.): P. aeruginosa, P. cepacia, P. fluorescens. Rhizoctonia (R.): $R$. solani. Rhodococcus (R.): R. rhodochrous. Saccharomyces (S.): S. cerevisiae. Salmonella (S.): S. abony, S. choleraesuis, S. gallinarum, S. typhi, S. typhimurium. Septoria (S.): S. glycines. Serratia (S.): S. marcescens. Shigella (S.): S. boydii. Staphylococcus (S.): S. aureus, S. enterica, S. epidermidis, S. lentus, S. xylosus. Streptococcus (S.): S. agalactiae, S. epidermis, S. mutans, S. pneumonia, S. pyogenes, S. sobrinus. Streptomyces (S.): S. purpurascens. Syspastospora (S.): S. parasitica. Trichophyton (T.): T. interdigitale, T. mentagrophytes, T. rubrum, T. tonsurans, Trichosporon (T.): T. mucoides. Trypanosoma (T.): T. cruzi. Vibrio (V.): V. alginolyticus, V. anguillarum, V. cholerae, V. fluvialis, $V$. haryevi, V. ordalii, V. parahaemolyticus, V. salmonicida, V. splendidus, V. tapetis, V. vulnificus. Yersinia (Y.): Y. ruckeri. Macroalgae species Chlorophyta: Boodlea (B.): B. coacta. Caulerpa (C.): C. peltata, C. prolifera, C. racemosa, C. scalpelliformis, C.

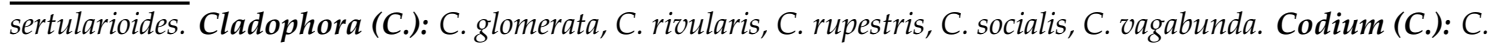
bursa, C. elongatum, C. fragile, C. iyengarii, C. tomentosum. Enteromorpha (E.): E. linza, E. prolifera. Halimeda (H.): H. tuna. Monostroma (M.): M. latissimum. Rhizoclonium (R.): R. implexum. Ulva (U.): U. fasciata, U. flexuosa, U. intestinalis, U. lactuca, U. meridionalis, U. ohnoi, U. pertusa, U. prolifera, U. rigida, U. reticulata. Valonopsis (V.): V. pachynema.

Rhodophyta: Acanthophora (A.): A. specifera. Actinotrichia (A.): A. fragilis. Ascophyllum (A.): A. nodosum. Ceramium (C.): C. ciliatum, C. rubrum. Chaetomorpha (C.): C. antemmina, C. linum. Chondrus (C.): C. crispus. Corallina (C.): C. elongata, C. officinalis. Digenea (D.): D. simplex. Dumontia (D.): D. contorta. Eucheuma (E.): E. serra. Galaxaura (G.): G. cylindriea, G. marginata. Gelidium (G.): G. amansii, G. corneum. Gigartina (G.): G. skottsbergii. Gracilaria (G.): G. birdiae, G. changii, G. corticata, G. dura, G. edulis, G. gracilis, G. lemaneiformis, G. multipartita, G. ornata, G. vermiculophylla. Gracilariopsis (G.): G. longissima. Grateloupia (G.): G. doryphora, G. lithophilia. Hypnea (H.): H. esperi, H. flagelliformis, H. musciformis. Jania (J.): J. rubens. Kappaphycus (K.): K. alvarezii. Laurencia (L.): L. aldingensis, L. brandenii, L. catarinensis, L. dendroidea, L. intricata, L. johnstonii, L. obtusa, L. paniculata, L. papillosa, L. translucida. Mastocarpus (M.): M. stellatus. Melanothamnus (M.): M. afaqhusainii. Osmundaria (O.): O. obtusiloba. Osmundea (O.): O. pinnatifida. Palmaria (P.): P. palmata. Polysiphonia (P.): P. elongata. Porphyra (P.): P. dioica, P. haitanensis. Portieria (P.): P. hornemannii. Pterocladia (P.): P. capillacea. Pterocladiella (P.): P. capillacea. Rissoella (R.): R. verruculosa. Rhodomela (R.): R. confervoides. Sarcodia (S.): S. ceylonensis. 
Ochrophyta: Bifurcaria (B.): B. bifurcata. Canistrocarpus (C.): C. cervicornis. Cladosiphon (C.): C. okamuranus.


Cutleria (C.): C. multifida. Cystoseira (C.): C. barbata, C. indica, C. mediterranea, C. myrica, C. nodicaulis, C. sedoides, C. trinodis, C. usneoides. Dictyopteris (D.): D. membranacea. Dictyota (D.): D. dichotoma, D. flabellata, D. indica. Dilophus (D.): D. fasciola. Ecklonia (E.): E. arborea, E. cava, E. kurome, E. radiata. Eisenia (E.): E. bicyclis. Feldmannia (F.): F. irregularis. Fucus (F.): F. evanescens, F. serratus, F. spiralis, F. vesiculosus. Gymnogongrus(G.): G. martinensis. Himanthalia (H.): H. elongata. Hormophysa (H.): H. cuneiformes. Iyengaria (I.): I. stellata. Jolyna (J.): J. laminarioides. Laminaria (L.): L. digitata, L. hyperborea, L. japonica. Lessonia (L.): L. nigrecens, L. trabeculata. Nizamuddinia (N.): N. zanardinii. Padina (P.): P. australis, P. concrescens, P. gymnospora. Pelvetia (P.): P. canaliculata. Porolithon (P.): P. antillarum, P. boergesenii. Saccharina (S.): S. latissima, S. longicruris. Sargassum (S.): S. angustifolium, S. boveanum, S. cinereum, S. dentifolium, S. hystrix, S. ilicifolium, S. incisifolium, S. latifolium, S. marginatum, S. muticum, S. myriocystum, S. oligocystum, S. pallidum, S. platycarpum, S. polycystum, S. portieriatum, S. swartzii, S. tenerrimum, S. thunbergii, S. variegatum, S. vulgare, S. wightii. Scytosiphon (S.): S. lomentaria. Solieria (S.): S. chordalis, S. filiformis, S. robusta. Spatoglossum (S.): S. asperum. Spyridia (S.): S. filamentosa. Stoechospermum (S.): S. marginatum. Taonia (T.): T. atomaria. Turbinaria (T.): T. conoides, T. decurrens, T. ornata, T. triquetra. Undaria (U.): U. pinnafitida.

\section{References}

1. Barbosa, F.; Pinto, E.; Kijjoa, A.; Pinto, M.; Sousa, E. Targeting antimicrobial drug resistance with marine natural products. Int. J. Antimicrob. Agents 2020, 5, 106005. [CrossRef] [PubMed]

2. Gnanavel, V.; Roopan, S.M.; Rajeshkumar, S. Aquaculture: An overview of chemical ecology of seaweeds (food species) in natural products. Aquaculture 2019, 507, 1-6. [CrossRef]

3. Lourenço-Lopes, C.; Fraga-Corral, M.; Jimenez-Lopez, C.; Pereira, A.G.; Garcia-Oliveira, P.; Carpena, M.; Prieto, M.A.; Simal-Gandara, J. Metabolites from Macroalgae and Its Applications in the Cosmetic Industry: A Circular Economy Approach. Resources 2020, 9, 101. [CrossRef]

4. Leandro, A.; Pereira, L.; Gonçalves, A.M.M. Diverse applications of marine macroalgae. Mar. Drugs 2020, 18, 17. [CrossRef]

5. Spalding, H.L.; Amado-Filho, G.M.; Bahia, R.G.; Ballantine, D.L.; Fredericq, S.; Leichter, J.J.; Nelson, W.A.; Slattery, M.; Tsuda, R.T. Macroalgae. In Mesophotic Coral Ecosystems; Springer: Cham, Switzerland, 2019; ISBN 978-3-319-92734-3.

6. Pepper, I.L.; Gentry, T.J. Microorganisms Found in the Environment. In Environmental Microbiology: Third Edition; Academic Press: Cambridge, MA, USA, 2015; pp. 9-36, ISBN 9780123946263.

7. Wells, M.L.; Potin, P.; Craigie, J.S.; Raven, J.A.; Merchant, S.S.; Helliwell, K.E.; Smith, A.G.; Camire, M.E.; Brawley, S.H. Algae as nutritional and functional food sources: Revisiting our understanding. J. Appl. Phycol. 2017, 29, 949-982. [CrossRef]

8. Anyanwu, R.C.; Rodriguez, C.; Durrant, A.; Olabi, A.G. Micro-Macroalgae Properties and Applications. Ref. Modul. Mater. Sci. Mater. Eng. 2018, 1-28. [CrossRef]

9. Praveen, M.A.; Parvathy, K.R.K.; Balasubramanian, P.; Jayabalan, R. An overview of extraction and purification techniques of seaweed dietary fibers for immunomodulation on gut microbiota. Trends Food Sci. Technol. 2019, 92, 46-64. [CrossRef]

10. Suleria, H.A.R.; Gobe, G.; Masci, P.; Osborne, S.A. Marine bioactive compounds and health promoting perspectives; innovation pathways for drug discovery. Trends Food Sci. Technol. 2016, 50, 44-55. [CrossRef]

11. Gurpilhares, D.d.B.; Cinelli, L.P.; Simas, N.K.; Pessoa, A.; Sette, L.D. Marine prebiotics: Polysaccharides and oligosaccharides obtained by using microbial enzymes. Food Chem. 2019, 280, 175-186. [CrossRef]

12. Belghit, I.; Rasinger, J.D.; Heesch, S.; Biancarosa, I.; Liland, N.; Torstensen, B.; Waagbø, R.; Lock, E.J.; Bruckner, C.G. In-depth metabolic profiling of marine macroalgae confirms strong biochemical differences between brown, red and green algae. Algal Res. 2017, 26, 240-249. [CrossRef]

13. Vuong, D.; Kaplan, M.; Lacey, H.J.; Crombie, A.; Lacey, E.; Piggott, A.M. A study of the chemical diversity of macroalgae from South Eastern Australia. Fitoterapia 2018, 126, 53-64. [CrossRef] [PubMed]

14. Bedoux, G.; Hardouin, K.; Burlot, A.S.; Bourgougnon, N. Bioactive components from seaweeds: Cosmetic Applications and Future Development; Elsevier: Amsterdam, The Netherlands, 2014; Volume 71, ISBN 9780124080621. 
15. Hamed, I.; Özogul, F.; Özogul, Y.; Regenstein, J.M. Marine Bioactive Compounds and Their Health Benefits: A Review. Compr. Rev. Food Sci. Food Saf. 2015, 14, 446-465. [CrossRef]

16. Silva, M.; Vieira, L.; Almeida, A.P.; Kijjoa, A. The Marine Macroalgae of the Genus Ulva: Chemistry, Biological Activities and Potential Applications. J. Oceanogr. Mar. Res. 2013, 1, 1-6. [CrossRef]

17. Mendes, M.; Pereira, R.; Sousa Pinto, I.; Carvalho, A.P.; Gomes, A.M. Antimicrobial activity and lipid profile of seaweed extracts from the North Portuguese Coast. Int. Food Res. J. 2013, 20, 3337-3345.

18. Buschmann, A.H.; Camus, C.; Infante, J.; Neori, A.; Israel, Á.; Hernández-González, M.C.; Pereda, S.V.; Gomez-Pinchetti, J.L.; Golberg, A.; Tadmor-Shalev, N.; et al. Seaweed production: Overview of the global state of exploitation, farming and emerging research activity. Eur. J. Phycol. 2017, 52, 391-406. [CrossRef]

19. Sharma, K.; Guleria, S.; Razdan, V.K.; Babu, V. Synergistic antioxidant and antimicrobial activities of essential oils of some selected medicinal plants in combination and with synthetic compounds. Ind. Crop. Prod. 2020, 154, 112569. [CrossRef]

20. Abu-Ghannam, N.; Rajauria, G. Antimicrobial activity of compounds isolated from algae. In Functional Ingredients from Algae for Foods and Nutraceuticals; Woodhead Publishing Limited: Shaston, UK, 2013; pp. 287-306, ISBN 9780857095121.

21. Roca, I.; Akova, M.; Baquero, F.; Carlet, J.; Cavaleri, M.; Coenen, S.; Cohen, J.; Findlay, D.; Gyssens, I.; Heure, O.E.; et al. The global threat of antimicrobial resistance: Science for intervention. New Microbes New Infect. 2015, 6, 22-29. [CrossRef]

22. Yılmaz Öztürk, B.; Yenice Gürsu, B.; Dağ, İ. Antibiofilm and antimicrobial activities of green synthesized silver nanoparticles using marine red algae Gelidium corneum. Process Biochem. 2020, 89, 208-219. [CrossRef]

23. Bhowmick, S.; Mazumdar, A.; Moulick, A.; Adam, V. Algal metabolites: An inevitable substitute for antibiotics. Biotechnol. Adv. 2020, 43, 107571. [CrossRef]

24. Hornsey, I.S.; Hide, D. The production of antimicrobial compounds by British marine algae I. Antibiotic-producing marine algae. Br. Phycol. J. 1974, 9, 353-361. [CrossRef]

25. Pina-Pérez, M.C.; Rivas, A.; Martínez, A.; Rodrigo, D. Antimicrobial potential of macro and microalgae against pathogenic and spoilage microorganisms in food. Food Chem. 2017, 235, 34-44. [CrossRef] [PubMed]

26. Chellat, M.F.; Raguž, L.; Riedl, R. Targeting Antibiotic Resistance. Angew. Chemie Int. Ed. 2016, 55, 6600-6626. [CrossRef] [PubMed]

27. Lewis, K. Platforms for antibiotic discovery. Nat. Rev. Drug Discov. 2013, 12, 371-387. [CrossRef] [PubMed]

28. Raguraman, V.; Stanley, A.L.; MubarakAli, D.; Narendrakumar, G.; Thirugnanasambandam, R.; Kirubagaran, R.; Thajuddin, N. Unraveling rapid extraction of fucoxanthin from Padina tetrastromatica: Purification, characterization and biomedical application. Process Biochem. 2018, 73, 211-219. [CrossRef]

29. Chemat, F.; Abert-Vian, M.; Fabiano-Tixier, A.S.; Strube, J.; Uhlenbrock, L.; Gunjevic, V.; Cravotto, G. Green extraction of natural products. Origins, current status, and future challenges. TrAC Trends Anal. Chem. 2019, 118, 248-263. [CrossRef]

30. Belwal, T.; Chemat, F.; Venskutonis, P.R.; Cravotto, G.; Jaiswal, D.K.; Bhatt, I.D.; Devkota, H.P.; Luo, Z. Recent advances in scaling-up of non-conventional extraction techniques: Learning from successes and failures. TrAC Trends Anal. Chem. 2020, 127, 115895. [CrossRef]

31. Baweja, P.; Kumar, S.; Sahoo, D.; Levine, I. Biology of Seaweeds. In Seaweed in Health and Disease Prevention; Elsevier Inc.: Amsterdam, The Netherlands, 2016; pp. 41-106, ISBN 9780128027936.

32. Cloutier, M.; Mantovani, D.; Rosei, F. Antibacterial Coatings: Challenges, Perspectives, and Opportunities. Trends Biotechnol. 2015, 33, 637-652. [CrossRef]

33. Pérez, M.J.; Falqué, E.; Domínguez, H. Antimicrobial action of compounds from marine seaweed. Mar. Drugs 2016, 14, 52. [CrossRef]

34. Shannon, E.; Abu-Ghannam, N. Antibacterial derivatives of marine algae: An overview of pharmacological mechanisms and applications. Mar. Drugs 2016, 14. [CrossRef]

35. Manilal, A.; Sujith, S.; Sabarathnam, B.; Kiran, G.S.; Selvin, J.; Shakir, C.; Lipton, A.P. Biological activity of the red alga Laurencia brandenii. Acta Bot. Croat. 2011, 70, 81-90. [CrossRef]

36. dos Santos Amorim, R.d.N.; Rodrigues, J.A.G.; Holanda, M.L.; Quinderé, A.L.G.; de Paula, R.C.M.; Melo, V.M.M.; Benevides, N.M.B. Antimicrobial effect of a crude sulfated polysaccharide from the red seaweed Gracilaria ornata. Brazilian Arch. Biol. Technol. 2012, 55, 171-181. [CrossRef] 
37. Cortés, Y.; Hormazábal, E.; Leal, H.; Urzúa, A.; Mutis, A.; Parra, L.; Quiroz, A. Novel antimicrobial activity of a dichloromethane extract obtained from red seaweed Ceramium rubrum (Hudson) (Rhodophyta: Florideophyceae) against Yersinia ruckeri and Saprolegnia parasitica, agents that cause diseases in salmonids. Electron. J. Biotechnol. 2014, 17, 126-131. [CrossRef]

38. Sasidharan, S.; Darah, I.; Noordin, M.K.M.J. In vitro antimicrobial activity against Pseudomonas aeruginosa and acute oral toxicity of marine algae Gracilaria changii. N. Biotechnol. 2010, 27, 390-396. [CrossRef] [PubMed]

39. de Alencar, D.B.; de Carvalho, F.C.T.; Rebouças, R.H.; dos Santos, D.R.; dos Santos Pires-Cavalcante, K.M.; de Lima, R.L.; Baracho, B.M.; Bezerra, R.M.; Viana, F.A.; dos Fernandes Vieira, R.H.S.; et al. Bioactive extracts of red seaweeds Pterocladiella capillacea and Osmundaria obtusiloba (Floridophyceae: Rhodophyta) with antioxidant and bacterial agglutination potential. Asian Pac. J. Trop. Med. 2016, 9, 372-379. [CrossRef]

40. Baliano, A.P.; Pimentel, E.F.; Buzin, A.R.; Vieira, T.Z.; Romão, W.; Tose, L.V.; Lenz, D.; de Andrade, T.U.; Fronza, M.; Kondratyuk, T.P.; et al. Brown seaweed Padina gymnospora is a prominent natural wound-care product. Rev. Bras. Farmacogn. 2016, 26, 714-719. [CrossRef]

41. Moubayed, N.M.S.; Al Houri, H.J.; Al Khulaifi, M.M.; Al Farraj, D.A. Antimicrobial, antioxidant properties and chemical composition of seaweeds collected from Saudi Arabia (Red Sea and Arabian Gulf). Saudi J. Biol. Sci. 2017, 24, 162-169. [CrossRef]

42. Kim, Y.H.; Kim, J.H.; Jin, H.J.; Lee, S.Y. Antimicrobial activity of ethanol extracts of Laminaria japonica against oral microorganisms. Anaerobe 2013, 21, 34-38. [CrossRef]

43. Akremi, N.; Cappoen, D.; Anthonissen, R.; Verschaeve, L.; Bouraoui, A. Phytochemical and in vitro antimicrobial and genotoxic activity in the brown algae Dictyopteris membranacea. S. Afr. J. Bot. 2017, 108, 308-314. [CrossRef]

44. Tajbakhsh, S.; Pouyan, M.; Zandi, K.; Bahramian, P.; Sartavi, K.; Fouladvand, M.; Asayesh, G.; Barazesh, A. In vitro study of antibacterial activity of the alga Sargassum oligocystum from the Persian Gulf. Eur. Rev. Med. Pharmacol. Sci. 2011, 15, 293-298.

45. Salem, W.M.; Galal, H.; Nasr El-deen, F. Screening for antibacterial activities in some marine algae from the red sea (Hurghada, Egypt). African J. Microbiol. Res. 2011, 5, 2160-2167. [CrossRef]

46. Chiao-Wei, C.; Siew-Ling, H.; Ching-Lee, W. Antibacterial activity of Sargassum polycystum C. Agardh and Padina australis Hauck (Phaeophyceae). Afr. J. Biotechnol. 2011, 10, 14125-14131. [CrossRef]

47. Assaw, S.; Rosli, N.L.; Azmi, N.A.M.; Mazlan, N.W.; Ismail, N. Antioxidant and antibacterial activities of polysaccharides and methanolic crude extracts of local edible red seaweed Gracilaria sp. Malaysian Appl. Biol. 2018, 47, 135-144.

48. Mashjoor, S.; Yousefzadi, M.; Esmaeili, M.A.; Rafiee, R. Cytotoxicity and antimicrobial activity of marine macro algae (Dictyotaceae and Ulvaceae) from the Persian Gulf. Cytotechnology 2016, 68, 1717-1726. [CrossRef] [PubMed]

49. Sirbu, R.; Stanciu, G.; Tomescu, A.; Ionescu, A.M.; Cadar, E. Evaluation of antioxidant and antimicrobial activity in relation to total phenolic content of green algae from Black Sea. Rev. Chim. 2019, 70, 1197-1203. [CrossRef]

50. Ismail, A.; Ktari, L.; Ben Redjem Romdhane, Y.; Aoun, B.; Sadok, S.; Boudabous, A.; El Bour, M. Antimicrobial Fatty Acids from Green Alga Ulva rigida (Chlorophyta). Biomed Res. Int. 2018, 2018. [CrossRef]

51. Abdel-Latif, H.H.; Shams El-Din, N.G.; Ibrahim, H.A.H. Antimicrobial activity of the newly recorded red alga Grateloupia doryphora collected from the Eastern Harbor, Alexandria, Egypt. J. Appl. Microbiol. 2018, 125, 1321-1332. [CrossRef]

52. Omar, H.H.; Shiekh, H.M.; Gumgumjee, N.M.; El-Kazan, M.M.; El-Gendy, A.M. Antibacterial activity of extracts of marine algae from the Red Sea of Jeddah, Saudi Arabia. Afr. J. Biotechnol. 2012, 11, 13576-13585. [CrossRef]

53. Al Khazan, M.M.; Omar, H.H.; Gumgumjee, N.M.; Shiekh, H.M.; El-Gendy, A.M. Marine macroalgae as a potential source of bioactive natural products with antibacterial activity. Main Group Chem. 2016, 15, 139-151. [CrossRef]

54. KOSANIĆ, M.; RANKOVIĆ, B.; Stanojković, T. Evaluation of antioxidant, antimicrobial and anticancer effects of three selected marine macroalgae. Rom. Biotechnol. Lett. 2018, 1-10.

55. Ambreen; Hira, K.; Tariq, A.; Ruqqia, R.; Sultana, V.; Jehan, A. Evaluation of biochemical component and antimicrobial activity of some seaweeeds occurring at Karachi coast. Pakistan J. Bot. 2012, 44, 1799-1803. 
56. Cavallo, R.A.; Acquaviva, M.I.; Stabili, L.; Cecere, E.; Petrocelli, A.; Narracci, M. Antibacterial activity of marine macroalgae against fish pathogenic Vibrio species. Cent. Eur. J. Biol. 2013, 8, 646-653. [CrossRef]

57. Stabili, L.; Acquaviva, M.I.; Biandolino, F.; Cavallo, R.A.; De Pascali, S.A.; Fanizzi, F.P.; Narracci, M.; Cecere, E.; Petrocelli, A. Biotechnological potential of the seaweed Cladophora rupestris (Chlorophyta, Cladophorales) lipidic extract. New Biotechnol. 2014, 31, 436-444. [CrossRef] [PubMed]

58. Stabili, L.; Acquaviva, M.I.; Biandolino, F.; Cavallo, R.A.; de Pascali, S.A.; Fanizzi, F.P.; Narracci, M.; Petrocelli, A.; Cecere, E. The lipidic extract of the seaweed Gracilariopsis longissima (Rhodophyta, Gracilariales): A potential resource for biotechnological purposes? New Biotechnol. 2012, 29, 443-450. [CrossRef] [PubMed]

59. Manikandan, S.; Ganesapandian, S.; Singh, M.; Sangeetha, N.; Kumaraguru, A.K. Antimicrobial activity of seaweeds against multi drug resistant strains. Int. J. Pharmacol. 2011, 7, 522-526. [CrossRef]

60. Osman, M.E.H.; Abushady, A.M.; Elshobary, M.E. In vitro screening of antimicrobial activity of extracts of some macroalgae collected from Abu-Qir bay Alexandria, Egypt. Afr. J. Biotechnol. 2010, 9, 7203-7208. [CrossRef]

61. Águila-Ramírez, R.N.; Arenas-González, A.; Hernández-Guerrero, C.J.; González-Acosta, B.; Borges-Souza, J.M.; Véron, B.; Pope, J.; Hellio, C. Antimicrobial and antifouling activities achieved by extracts of seaweeds from Gulf of California, Mexico. Hidrobiologica 2012, 22, 8-15.

62. Lee, J.-H.; Eom, S.-H.; Lee, E.-H.; Jung, Y.-J.; Kim, H.-J.; Jo, M.-R.; Son, K.-T.; Lee, H.-J.; Kim, J.H.; Lee, M.-S.; et al. In vitro antibacterial and synergistic effect of phlorotannins isolated from edible brown seaweed Eisenia bicyclis against acne-related bacteria. ALGAE 2014. [CrossRef]

63. Tajbakhsh, S.; Ilkhani, M.; Rustaiyan, A.; Larijani, K.; Sartavi, K.; Tahmasebi, R.; Asayesh, G. Antibacterial effect of the brown alga Cystoseira trinodis. J. Med. Plant Res. 2011, 5, 4654-4657.

64. Ertürk, Ö.; Taş, B. Antibacterial and antifungal effects of some marine algae. Kafkas Univ. Vet. Fak. Derg. 2011, 17, 121-124.

65. Ghania, A.; Nabila, B.B.; Larbi, B.; Elisabeth, M.; Philippe, G.; Mariem, B.; Khadidja, K.K.; Wacila, B.R.; Fawzia, A.B. Antimicrobial and antiparasitic activities of three algae from the northwest coast of Algeria. Nat. Prod. Res. 2019, 33, 742-745. [CrossRef]

66. Stein, E.M.; Colepicolo, P.; Afonso, F.A.K.; Fujii, M.T. Screening for antifungal activities of extracts of the Brazilian seaweed genus Laurencia (Ceramiales, Rhodophyta). Braz. J. Pharmacogn. 2011, 21, 290-295. [CrossRef]

67. Aoun, Z.B.; Said, R.B.; Farhat, F. Anti-inflammatory, antioxidant and antimicrobial activities of aqueous and organic extracts from Dictyopteris membranacea. Bot. Mar. 2010, 53, 259-264. [CrossRef]

68. Rosaline, X.D.; Sakthivelkumar, S.; Rajendran, K.; Janarthanan, S. Screening of selected marine algae from the coastal Tamil Nadu, South India for antibacterial activity. Asian Pac. J. Trop. Biomed. 2012, 2. [CrossRef]

69. Goecke, F.; Labes, A.; Wiese, J.; Imhoff, J.F. Dual effect of macroalgal extracts on growth of bacteria in Western Baltic Sea. Rev. Biol. Mar. Oceanogr. 2012, 47, 75-86. [CrossRef]

70. Milović, S.; Kundaković, T.; Mačić, V.; Stanković, J.A.; Grozdanić, N.; Đuričić, I.; Stanković, I.; Stanojković, T. Anti $\alpha$-glucosidase, antitumour, antioxidative, antimicrobial activity, nutritive and health protective potential of some seaweeds from the Adriatic coast of Montenegro. Farmacia 2017, 65, 731-740.

71. Arulkumar, A.; Rosemary, T.; Paramasivam, S.; Rajendran, R.B. Phytochemical composition, in vitro antioxidant, antibacterial potential and GC-MS analysis of red seaweeds (Gracilaria corticata and Gracilaria edulis) from Palk Bay, India. Biocatal. Agric. Biotechnol. 2018, 15, 63-71. [CrossRef]

72. Cox, S.; Abu-Ghannam, N.; Gupta, S. An assessment of the antioxidant and antimicrobial activity of six species of edible Irish seaweeds. Int. Food Res. J. 2010, 17, 205-220. [CrossRef]

73. Arumugam, G.; Rajendran, R. Anti-candidal activity and synergetic interaction of antifungal drugs with differential extract of brown algae Stocheospermum marginatum. Biocatal. Agric. Biotechnol. 2019, 19, 101145. [CrossRef]

74. Taskin, E.; Caki, Z.; Ozturk, M.; Taskin, E. Assessment of in vitro antitumoral and antimicrobial activities of marine algae harvested from the eastern Mediterranean sea. Afr. J. Biotechnol. 2010, 9, 4272-4277. [CrossRef]

75. Kosanić, M.; Ranković, B.; Stanojković, T. Biological activities of two macroalgae from Adriatic coast of Montenegro. Saudi J. Biol. Sci. 2015, 22, 390-397. [CrossRef]

76. Osman, N.A.H.K.; Siam, A.A.; El-manawy, I.M.; Jeon, Y. Anti-microbial and Anti-diabetic Activity of Six Seaweeds Collected from the Red Sea, Egypt. Catrina Int. J. Environ. Sci. 2019, 19, 55-60. 
77. Kang, O.; Brice, O.; Lee, Y.; Chae, H. Antibacterial activity of Ecklonia cava against methicillin-resistant Staphylococcus aureus and Salmonella spp. Foodborne Pathog. Dis. 2010, 7, 435-441. [CrossRef]

78. Abdel-Raouf, N.; Mohamed, H.; Mostafa, S.; Ibraheem, I. Controlling of Microbial Growth by Using Cystoseira barbata Extract. Egypt. J. Bot. 2017, 57, 469-477. [CrossRef]

79. Bhuyar, P.; Rahim, M.H.; Sundararaju, S.; Maniam, G.P.; Govindan, N. Antioxidant and antibacterial activity of red seaweed; Kappaphycus alvarezii against pathogenic bacteria. Glob. J. Environ. Sci. Manag. 2020, 5, 47-58. [CrossRef]

80. Guedes, E.A.C.; dos Santos Araújo, M.A.; Souza, A.K.P.; de Souza, L.I.O.; de Barros, L.D.; de Albuquerque Maranhão, F.C.; Sant'Ana, A.E.G. Antifungal Activities of Different Extracts of Marine Macroalgae Against Dermatophytes and Candida Species. Mycopathologia 2012, 174, 223-232. [CrossRef]

81. Alves, C.; Pinteus, S.; Simões, T.; Horta, A.; Silva, J.; Tecelão, C.; Pedrosa, R. Bifurcaria bifurcata: A key macro-alga as a source of bioactive compounds and functional ingredients. Int. J. Food Sci. Technol. 2016, 51, 1638-1646. [CrossRef]

82. Jassbi, A.R.; Mohabati, M.; Eslami, S.; Sohrabipour, J.; Miri, R. Biological activity and chemical constituents of red and brown algae from the Persian Gulf. Iran. J. Pharm. Res. 2013, 12, 339-348. [CrossRef]

83. Shanmugam, S.K.; Kumar, Y.; Yar, K.M.S.; Gupta, V.; de Clercq, E. Antimicrobial and cytotoxic activities of Turbinaria conoides (J.Agardh) Kuetz. Iran. J. Pharm. Res. 2010, 9, 411-416. [CrossRef]

84. Kosanić, M.; Ranković, B.; Stanojković, T. Brown macroalgae from the Adriatic Sea as a promising source of bioactive nutrients. J. Food Meas. Charact. 2019, 13, 330-338. [CrossRef]

85. Chan, Y.S.; Ong, C.W.; Chuah, B.L.; Khoo, K.S.; Chye, F.Y.; Sit, N.W. Antimicrobial, antiviral and cytotoxic activities of selected marine organisms collected from the coastal areas of Malaysia. J. Mar. Sci. Technol. 2018, 26, 128-136. [CrossRef]

86. Deveau, A.M.; Miller-Hope, Z.; Lloyd, E.; Williams, B.S.; Bolduc, C.; Meader, J.M.; Weiss, F.; Burkholder, K.M. Antimicrobial activity of extracts from macroalgae Ulva lactuca against clinically important Staphylococci is impacted by lunar phase of macroalgae harvest. Lett. Appl. Microbiol. 2016, 62, 363-371. [CrossRef] [PubMed]

87. Rahelivao, M.P.; Gruner, M.; Andriamanantoanina, H.; Bauer, I.; Knölker, H.J. Brown Algae (Phaeophyceae) from the Coast of Madagascar: Preliminary Bioactivity Studies and Isolation of Natural Products. Nat. Products Bioprospect. 2015, 5, 223-235. [CrossRef]

88. Mickymaray, S.; Alturaiki, W. Antifungal efficacy of marine macroalgae against fungal isolates from bronchial asthmatic cases. Molecules 2018, 23, 3032. [CrossRef]

89. Selim, S.; Amin, A.; Hassan, S.; Hagazey, M. Antibacterial, cytotoxicity and anticoagulant activities from Hypnea esperi and Caulerpa prolifera marine algae. Pak. J. Pharm. Sci. 2015, 28, 525-530. [PubMed]

90. Rahelivao, M.P.; Gruner, M.; Andriamanantoanina, H.; Andriamihaja, B.; Bauer, I.; Knölker, H.J. Red algae (Rhodophyta) from the coast of Madagascar: Preliminary bioactivity studies and isolation of natural products. Mar. Drugs 2015, 13, 4197-4216. [CrossRef]

91. Rajauria, G.; Jaiswal, A.K.; Abu-Gannam, N.; Gupta, S. Antimicrobial, antioxidant and free radical-scavenging capacity of brown seaweed Himanthalia elongata from western coast of Ireland. J. Food Biochem. 2013, 37, 322-335. [CrossRef]

92. Higgins Hoare, A.; Tan, S.P.; McLoughlin, P.; Mulhare, P.; Hughes, H. The Screening and Evaluation of Fucus serratus and Fucus vesiculosus Extracts against Current Strains of MRSA Isolated from a Clinical Hospital Setting. Sci. Rep. 2019, 9, 1-9. [CrossRef]

93. Van Tran, T.T.; Truong, H.B.; Tran, N.H.V.; Quach, T.M.T.; Nguyen, T.N.; Bui, M.L.; Yuguchi, Y.; Thanh, T.T.T. Structure, conformation in aqueous solution and antimicrobial activity of ulvan extracted from green seaweed Ulva reticulata. Nat. Prod. Res. 2018, 32, 2291-2296. [CrossRef]

94. Trigui, M.; Gasmi, L.; Zouari, I.; Tounsi, S. Seasonal variation in phenolic composition, antibacterial and antioxidant activities of Ulva rigida (Chlorophyta) and assessment of antiacetylcholinesterase potential. J. Appl. Phycol. 2013, 25, 319-328. [CrossRef]

95. Vijayavel, K.; Martinez, J.A. In vitro antioxidant and antimicrobial activities of two Hawaiian marine Limu: Ulva fasciata (Chlorophyta) and Gracilaria salicornia (Rhodophyta). J. Med. Food 2010, 13, 1494-1499. [CrossRef]

96. Zouaoui, B.; Ghalem, B.R. The Phenolic Contents and Antimicrobial Activities of Some Marine Algae from the Mediterranean Sea (Algeria). Russ. J. Mar. Biol. 2017, 43, 491-495. [CrossRef] 
97. Vieira, E.F.; Soares, C.; Machado, S.; Correia, M.; Ramalhosa, M.J.; Oliva-teles, M.T.; Paula Carvalho, A.; Domingues, V.F.; Antunes, F.; Oliveira, T.A.C.; et al. Seaweeds from the Portuguese coast as a source of proteinaceous material: Total and free amino acid composition profile. Food Chem. 2018, 269, $264-275$. [CrossRef] [PubMed]

98. Cherry, P.; Yadav, S.; Strain, C.R.; Allsopp, P.J.; Mcsorley, E.M.; Ross, R.P.; Stanton, C. Prebiotics from seaweeds: An ocean of opportunity? Mar. Drugs 2019, 17, 327. [CrossRef] [PubMed]

99. Ciko, A.M.; Jokić, S.; Šubarić, D.; Jerković, I. Overview on the application of modern methods for the extraction of bioactive compounds from marine macroalgae. Mar. Drugs 2018, 16, 348. [CrossRef] [PubMed]

100. Bak, U.G.; Nielsen, C.W.; Marinho, G.S.; Gregersen, Ó.; Jónsdóttir, R.; Holdt, S.L. The seasonal variation in nitrogen, amino acid, protein and nitrogen-to-protein conversion factors of commercially cultivated Faroese Saccharina latissima. Algal Res. 2019, 42, 101576. [CrossRef]

101. Stack, J.; Tobin, P.R.; Gietl, A.; Harnedy, P.A.; Stengel, D.B.; FitzGerald, R.J. Seasonal variation in nitrogenous components and bioactivity of protein hydrolysates from Porphyra dioica. J. Appl. Phycol. 2017, 29, 2439-2450. [CrossRef]

102. Pangestuti, R.; Kim, S. Seaweed proteins, peptides, and amino acids. In Seaweed Sustainablity; Elsevier Inc.: Amsterdam, The Netherlands, 2015; pp. 125-140, ISBN 9780124186972.

103. Cerná, M. Seaweed Proteins and Amino Acids as Nutraceuticals. In Advances in Food and Nutrition Research; Elsevier Inc.: Amsterdam, The Netherlands, 2011; Volume 64, pp. 297-312, ISBN 9780123876690.

104. Admassu, H.; Abdalbasit, M.; Yang, R.; Zhao, W.; War, W. Bioactive Peptides Derived from Seaweed Protein and Their Health Benefits: Antihypertensive, Antioxidant, and Antidiabetic Properties. J. Food Sci. 2018, 83, 6-16. [CrossRef]

105. Beaulieu, L.; Bondu, S.; Doiron, K.; Rioux, L.; Turgeon, S.L. Characterization of antibacterial activity from protein hydrolysates of the macroalga Saccharina longicruris and identification of peptides implied in bioactivity. J. Funct. Foods 2015, 17, 685-697. [CrossRef]

106. Cordeiro, R.A.; Gomes, V.M.; Carvalho, A.F.U.; Melo, V.M.M. Effect of proteins from the red seaweed Hypnea musciformis (Wulfen) lamouroux on the growth of human pathogen yeasts. Braz. Arch. Biol. Technol. 2006, 49, 915-921. [CrossRef]

107. Holanda, M.L.; Melo, V.M.M.; Silva, L.M.C.M.; Amorim, R.C.N.; Pereira, M.G.; Benevides, N.M.B. Differential activity of a lectin from Solieria filiformis against human pathogenic bacteria. Brazilian J. Med. Biol. Res. 2005, 38, 1769-1773. [CrossRef]

108. Xu, S.; Huang, X.; Cheong, K. Recent Advances in Marine Algae Polysaccharides: Isolation, Structure, and Activities. Mar. Drugs 2017, 15, 388. [CrossRef] [PubMed]

109. Berri, M.; Olivier, M.; Holbert, S.; Dupont, J.; Demais, H.; Le Goff, M.; Collen, P.N. Ulvan from Ulva armoricana (Chlorophyta) activates the PI3K/Akt signalling pathway via TLR4 to induce intestinal cytokine production. Algal Res. 2017, 28, 39-47. [CrossRef]

110. Cho, M.; You, S. Sulfated Polysaccharides from Green Seaweeds. In Springer Handbook of Marine Biotechnology; Springer: Berlin/Heidelberg, Germany, 2015; pp. 941-953.

111. Bouhlal, R.; Haslin, C.; Chermann, J.C.; Colliec-Jouault, S.; Sinquin, C.; Simon, G.; Cerantola, S.; Riadi, H.; Bourgougnon, N. Antiviral activities of sulfated polysaccharides isolated from Sphaerococcus coronopifolius (Rhodophytha, Gigartinales) and Boergeseniella thuyoides (Rhodophyta, Ceramiales). Mar. Drugs 2011, 9, 1187-1209. [CrossRef] [PubMed]

112. Ermakova, S.; Men'shova, R.; Vishchuk, O.; Kim, S.M.; Um, B.H.; Isakov, V.; Zvyagintseva, T. Water-soluble polysaccharides from the brown alga Eisenia bicyclis: Structural characteristics and antitumor activity. Algal Res. 2013, 2, 51-58. [CrossRef]

113. De Jesus Raposo, M.F.; De Morais, A.M.B.; De Morais, R.M.S.C. Marine polysaccharides from algae with potential biomedical applications. Mar. Drugs 2015, 13, 2967-3028. [CrossRef] [PubMed]

114. O'Doherty, J.V.; McDonnell, P.; Figat, S. The effect of dietary laminarin and fucoidan in the diet of the weanling piglet on performance and selected faecal microbial populations. Livest. Sci. 2010, 134, 208-210. [CrossRef]

115. Belattmania, Z.; Engelen, A.H.; Pereira, H.; Serrão, E.A.; Custódio, L.; Varela, J.C.; Zrid, R.; Reani, A.; Sabour, B. Fatty acid composition and nutraceutical perspectives of brown seaweeds from the Atlantic coast of Morocco. Int. Food Res. J. 2018, 25, 1520-1527. 
116. Kendel, M.; Wielgosz-Collin, G.; Bertrand, S.; Roussakis, C.; Bourgougnon, N.B.; Bedoux, G. Lipid composition, fatty acids and sterols in the seaweeds ulva armoricana, and solieria chordalis from brittany (France): An analysis from nutritional, chemotaxonomic, and antiproliferative activity perspectives. Mar. Drugs 2015, 13, 5606-5628. [CrossRef]

117. Schmid, M.; Guihéneuf, F.; Stengel, D.B. Fatty acid contents and profiles of 16 macroalgae collected from the Irish Coast at two seasons. J. Appl. Phycol. 2014, 26, 451-463. [CrossRef]

118. Cardoso, C.; Ripol, A.; Afonso, C.; Freire, M.; Varela, J.; Quental-Ferreira, H.; Pousão-Ferreira, P.; Bandarra, N. Fatty acid profiles of the main lipid classes of green seaweeds from fish pond aquaculture. Food Sci. Nutr. 2017, 5, 1186-1194. [CrossRef]

119. El Baz, F.K.; El Baroty, G.S.; Abd El Baky, H.H.; Abd El-Salam, O.I.; Ibrahim, E.A. Structural characterization and biological activity of sulfolipids from selected marine algae. Grasas y Aceites 2013, 64, 561-571. [CrossRef]

120. Mekinić, I.G.; Skroza, D.; Šimat, V.; Hamed, I.; Čagalj, M.; Perković, Z.P. Phenolic content of brown algae (Pheophyceae) species: Extraction, identification, and quantification. Biomolecules 2019, 9, 244. [CrossRef]

121. Gómez-Guzmán, M.; Rodríguez-Nogales, A.; Algieri, F.; Gálvez, J. Potential role of seaweed polyphenols in cardiovascular-associated disorders. Mar. Drugs 2018, 16, 250. [CrossRef] [PubMed]

122. Cassani, L.; Gomez-zavaglia, A.; Jimenez-lopez, C.; Prieto, M.A.; Simal-gandara, J. Seaweed-based natural ingredients: Stability of phlorotannins during extraction, storage, passage through the gastrointestinal tract and potential incorporation into functional foods. Food Res. Int. 2020, 109676. [CrossRef]

123. Montero, L.; del Pilar Sánchez-Camargo, A.; Ibáñez, E.; Gilbert-López, B. Phenolic Compounds from Edible Algae: Bioactivity and Health Benefits. Curr. Med. Chem. 2017, 25, 4808-4826. [CrossRef]

124. Yuan, Y.; Zhang, J.; Fan, J.; Clark, J.; Shen, P.; Li, Y.; Zhang, C. Microwave assisted extraction of phenolic compounds from four economic brown macroalgae species and evaluation of their antioxidant activities and inhibitory effects on $\alpha$-amylase, $\alpha$-glucosidase, pancreatic lipase and tyrosinase. Food Res. Int. 2018, 113, 288-297. [CrossRef]

125. Nagayama, K.; Iwamura, Y.; Shibata, T.; Hirayama, I.; Nakamura, T. Bactericidal activity of phlorotannins from the brown alga Ecklonia kurome. J. Antimicrob. Chemother. 2002, 50, 889-893. [CrossRef]

126. Aryee, A.N.; Agyei, D.; Akanbi, T.O. Recovery and utilization of seaweed pigments in food processing. Curr. Opin. Food Sci. 2018, 19, 113-119. [CrossRef]

127. Michalak, I.; Chojnacka, K. Algae as production systems of bioactive compounds. Eng. Life Sci. 2015, 15, 160-176. [CrossRef]

128. Karpinski, T.M.; Adamczak, A. Fucoxanthin-An Antibacterial Carotenoid. Antioxidants 2019, 8, 239. [CrossRef]

129. Bogolitsyn, K.; Dobrodeeva, L.; Druzhinina, A.; Ovchinnikov, D.; Parshina, A.; Shulgina, E. Biological activity of a polyphenolic complex of Arctic brown algae. J. Appl. Phycol. 2019, 31, 3341-3348. [CrossRef]

130. Wei, Y.; Liu, Q.; Xu, C.; Yu, J.; Zhao, L.; Guo, Q. Damage to the Membrane Permeability and Cell Death of Vibrio parahaemolyticus Caused by Phlorotannins with Low Molecular Weight from Sargassum thunbergii. J. Aquat. Food Prod. Technol. 2016, 25, 323-333. [CrossRef]

131. Eom, S.H.; Lee, D.S.; Jung, Y.J.; Park, J.H.; Choi, J.I.; Yim, M.J.; Jeon, J.M.; Kim, H.W.; Son, K.T.; Je, J.Y.; et al. The mechanism of antibacterial activity of phlorofucofuroeckol-A against methicillin-resistant Staphylococcus aureus. Appl. Microbiol. Biotechnol. 2014, 98, 9795-9804. [CrossRef] [PubMed]

132. Cherian, C.; Jannet Vennila, J.; Sharan, L. Marine bromophenols as an effective inhibitor of virulent proteins (peptidyl arginine deiminase, gingipain $\mathrm{R}$ and hemagglutinin A) in Porphyromas gingivalis. Arch. Oral Biol. 2019, 100, 119-128. [CrossRef] [PubMed]

133. Lee, M.H.; Lee, K.B.; Oh, S.M.; Lee, B.H.; Chee, H.Y. Antifungal activities of dieckol isolated from the marine brown alga Ecklonia cava against Trichophyton rubrum. J. Appl. Biol. Chem. 2010, 53, 504-507. [CrossRef]

134. Lopes, G.; Pinto, E.; Andrade, P.B.; Valentão, P. Antifungal Activity of Phlorotannins against Dermatophytes and Yeasts: Approaches to the Mechanism of Action and Influence on Candida albicans Virulence Factor. PLoS ONE 2013, 8, e72203. [CrossRef]

135. Ryu, Y.B.; Jeong, H.J.; Yoon, S.Y.; Park, J.Y.; Kim, Y.M.; Park, S.J.; Rho, M.C.; Kim, S.J.; Lee, W.S. Influenza virus neuraminidase inhibitory activity of phlorotannins from the edible brown alga Ecklonia cava. J. Agric. Food Chem. 2011, 59, 6467-6473. [CrossRef] 
136. Morán-Santibañez, K.; Peña-Hernáncez, M.A.; Cruz-Suárez, L.E.; Ricque-Marie, D.; Skouta, R.; Vasquez, A.H.; Rodríguez-Padilla, C.; Trejo-Avila, L.M. Virucidal and Synergistic Activity of Polyphenol-Rich Extracts of Seaweeds against Measles Virus. Viruses 2018, 10, 465. [CrossRef]

137. Liu, M.; Liu, Y.; Cao, M.; Liu, G.; Chen, Q.; Sun, L.; Chen, H. Antibacterial activity and mechanisms of depolymerized fucoidans isolated from Laminaria japonica. Carbohydr. Polym. 2017, 172, 294-305. [CrossRef]

138. Id, J.J.; Jung, M.; Jeong, I.; Yamazaki, K.; Kawai, Y. Antimicrobial and Antibiofilm Activities of Sulfated Polysaccharides from Marine Algae against Dental. Mar. Drugs 2018, 16, 301. [CrossRef]

139. Kadam, S.U.; Donnell, C.P.O.; Rai, D.K.; Hossain, M.B.; Burgess, C.M.; Walsh, D.; Tiwari, B.K. Laminarin from Irish brown seaweeds Ascophyllum nodosum and Laminaria hyperborea: Ultrasound assisted extraction, characterization and bioactivity. Mar. Drugs 2015, 13, 4270-4280. [CrossRef] [PubMed]

140. Zeid, A.H.A.; Aboutabl, E.A.; Sleem, A.A.; El-rafie, H.M. Water soluble polysaccharides extracted from Pterocladia capillacea and Dictyopteris membranacea and their biological activities. Carbohydr. Polym. 2014, 113, 62-66. [CrossRef] [PubMed]

141. Siahaan, E.A.; Pangestuti, R.; Kim, S.-K. Seaweeds: Valuable Ingredients for the Pharmaceutical Industries; Springer: Cham, Siwtzerland, 2018; ISBN 9783319690759.

142. Singh, R.S.; Walia, A.K. Lectins from red algae and their biomedical potential. J. Appl. Phycol. 2018, 30, 1833-1858. [CrossRef] [PubMed]

143. Cheung, R.C.F.; Wong, J.H.; Pan, W.; Chan, Y.S.; Yin, C.; Dan, X.; Ng, T.B. Marine lectins and their medicinal applications. Appl. Microbiol. Biotechnol. 2015, 99, 3755-3773. [CrossRef]

144. El Shafay, S.M.; Ali, S.S.; El-Sheekh, M.M. Antimicrobial activity of some seaweeds species from Red sea, against multidrug resistant bacteria. Egypt. J. Aquat. Res. 2016, 42, 65-74. [CrossRef]

145. Kasanah, N.; Amelia, W.; Mukminin, A.; Triyanto; Isnansetyo, A. Antibacterial activity of Indonesian red algae Gracilaria edulis against bacterial fish pathogens and characterization of active fractions. Nat. Prod. Res. 2019, 33, 3303-3307. [CrossRef]

146. Anjali, K.P.; Sangeetha, B.M.; Devi, G.; Raghunathan, R.; Dutta, S. Bioprospecting of seaweeds (Ulva lactuca and Stoechospermum marginatum): The compound characterization and functional applications in medicine-a comparative study. J. Photochem. Photobiol. B Biol. 2019, 200, 111622. [CrossRef]

147. de Felício, R.; de Albuquerque, S.; Young, M.C.M.; Yokoya, N.S.; Debonsi, H.M. Trypanocidal, leishmanicidal and antifungal potential from marine red alga Bostrychia tenella J. Agardh (Rhodomelaceae, Ceramiales). J. Pharm. Biomed. Anal. 2010, 52, 763-769. [CrossRef]

148. Wang, H.; Li, Y.; Shen, W.; Rui, W.; Ma, X.; Cen, Y. Antiviral activity of a sulfoquinovosyldiacylglycerol ( SQDG ) compound isolated from the green alga Caulerpa racemosa. Bot. Mar. 2007, 50, 185-190. [CrossRef]

149. Rajauria, G.; Abu-ghannam, N. Isolation and Partial Characterization of Bioactive Fucoxanthin from Himanthalia elongata Brown Seaweed: A TLC-Based Approach. Int. J. Anal. Chem. 2013, 2013. [CrossRef]

150. Gerasimenko, N.I.; Martyyas, E.A.; Logvinov, S.V.; Busarova, N.G. Biological activity of lipids and photosynthetic pigments of Sargassum pallidum C. Agardh. Appl. Biochem. Microbiol. 2014, 50, 73-81. [CrossRef]

151. Mendiola, J.A.; Santoyo, S.; Cifuentes, A.; Reglero, G.; Ibáñez, E.; Javier Señoráns, F. Antimicrobial activity of sub- and supercritical CO2 extracts of the green alga Dunaliella salina. J. Food Prot. 2008, 71, 2138-2143. [CrossRef] [PubMed]

152. Tyskiewicz, K.; Tyskiewicz, R.; Konkol, M.; Rój, E.; Jaroszuk-Sciseł, J.; Skalicka-Wozniak, K. Antifungal Properties of Fucus vesiculosus L. Supercritical Fluid Extract against Fusarium culmorum and Fusarium oxysporum. Molecules 2019, 24. [CrossRef]

153. Alboofetileh, M.; Rezaei, M.; Tabarsa, M.; Rittà, M.; Donalisio, M.; Mariatti, F.; You, S.G.; Lembo, D.; Cravotto, G. Effect of different non-conventional extraction methods on the antibacterial and antiviral activity of fucoidans extracted from Nizamuddinia zanardinii. Int. J. Biol. Macromol. 2019, 124, 131-137. [CrossRef] [PubMed]

154. Munir, N.; Rafique, M.; Altaf, I.; Sharif, N.; Naz, S. Antioxidant and antimicrobial activities of extracts from selected algal species. Bangladesh J. Bot. 2018, 47, 53-61.

155. Sabeena, S.F.; Alagarsamy, S.; Sattari, Z.; Al-Haddad, S.; Fakhraldeen, S.; Al-Ghunaim, A.; Al-Yamani, F. Enzyme-assisted extraction of bioactive compounds from brown seaweeds and characterization. J. Appl. Phycol. 2020, 32, 615-629. [CrossRef] 
156. Meillisa, A.; Siahaan, E.A.; Park, J.N.; Woo, H.C.; Chun, B.S. Effect of subcritical water hydrolysate in the brown seaweed Saccharina japonica as a potential antibacterial agent on food-borne pathogens. J. Appl. Phycol. 2013, 25, 763-769. [CrossRef]

157. Otero, P.; Quintana, S.E.; Reglero, G.; Fornari, T.; García-Risco, M.R. Pressurized Liquid Extraction (PLE) as an innovative green technology for the effective enrichment of galician algae extracts with high quality fatty acids and antimicrobial and antioxidant properties. Mar. Drugs 2018, 16. [CrossRef]

158. Plaza, M.; Santoyo, S.; Jaime, L.; García-Blairsy Reina, G.; Herrero, M.; Señoráns, F.J.; Ibáñez, E. Screening for bioactive compounds from algae. J. Pharm. Biomed. Anal. 2010, 51, 450-455. [CrossRef]

159. Heavisides, E.; Rouger, C.; Reichel, A.F.; Ulrich, C.; Wenzel-Storjohann, A.; Sebens, S.; Tasdemir, D. Seasonal variations in the metabolome and bioactivity profile of fucus vesiculosus extracted by an optimised, pressurised liquid extraction protocol. Mar. Drugs 2018, 16, 503. [CrossRef]

160. Sosa-Hernández, J.E.; Escobedo-Avellaneda, Z.; Iqbal, H.M.N.; Welti-Chanes, J. State-of-the-art extraction methodologies for bioactive compounds from algal biome to meet bio-economy challenges and opportunities. Molecules 2018, 23. [CrossRef] [PubMed]

161. Gallego, R.; Bueno, M.; Herrero, M. Sub- and supercritical fl uid extraction of bioactive compounds from plants, food-by-products, seaweeds and microalgae-An update. Trends Anal. Chem. 2019, 116, 198-213. [CrossRef]

162. Saravana, P.S.; Getachew, A.T.; Cho, Y.J.; Choi, J.H.; Park, Y.B.; Woo, H.C.; Chun, B.S. Influence of co-solvents on fucoxanthin and phlorotannin recovery from brown seaweed using supercritical CO2. J. Supercrit. Fluids 2017, 120, 295-303. [CrossRef]

163. Bogolitsyn, K.G.; Kaplitsin, P.A.; Dobrodeeva, L.K.; Druzhinina, A.S.; Ovchinnikov, D.V.; Parshina, A.E.; Shulgina, E.V. Fatty Acid Composition and Biological Activity of Supercritical Extracts from Arctic Brown Algae Fucus vesiculosus. Russ. J. Phys. Chem. B 2017, 11, 1144-1152. [CrossRef]

164. Fabrowska, J.; Messyasz, B.; Pankiewicz, R.; Wilińska, P.; Łęska, B. Seasonal differences in the content of phenols and pigments in thalli of freshwater Cladophora glomerata and its habitat. Water Res. 2018, 135, 66-74. [CrossRef]

165. Tiwari, B.K. Ultrasound: A clean, green extraction technology. TrAC Trends Anal. Chem. 2015, 71, 100-109. [CrossRef]

166. Adam, F.; Abert-Vian, M.; Peltier, G.; Chemat, F. “Solvent-free" ultrasound-assisted extraction of lipids from fresh microalgae cells: A green, clean and scalable process. Bioresour. Technol. 2012, 114, 457-465. [CrossRef]

167. Chemat, F.; Rombaut, N.; Sicaire, A.G.; Meullemiestre, A.; Fabiano-Tixier, A.S.; Abert-Vian, M. Ultrasound assisted extraction of food and natural products. Mechanisms, techniques, combinations, protocols and applications. A review. Ultrason. Sonochem. 2017, 34, 540-560. [CrossRef]

168. Kadam, S.U.; Tiwari, B.K.; Smyth, T.J.; O’Donnell, C.P. Optimization of ultrasound assisted extraction of bioactive components from brown seaweed Ascophyllum nodosum using response surface methodology. Ultrason. Sonochem. 2015, 23, 308-316. [CrossRef]

169. Rodríguez-Bernaldo de Quirós, A.; Lage-Yusty, M.A.; López-Hernández, J. Determination of phenolic compounds in macroalgae for human consumption. Food Chem. 2010, 121, 634-638. [CrossRef]

170. Garcia-Vaquero, M.; Rajauria, G.; Tiwari, B.; Sweeney, T.; O’Doherty, J. Extraction and yield optimisation of fucose, glucans and associated antioxidant activities from laminaria digitata by applying response surface methodology to high intensity ultrasound-assisted extraction. Mar. Drugs 2018, 16. [CrossRef] [PubMed]

171. Topuz, O.K.; Gokoglu, N.; Yerlikaya, P.; Ucak, I.; Gumus, B. Optimization of Antioxidant Activity and Phenolic Compound Extraction Conditions from Red Seaweed (Laurencia obtuse). J. Aquat. Food Prod. Technol. 2015, 25, 414-422. [CrossRef]

172. Garcia-Vaquero, M.; Ummat, V.; Tiwari, B.; Rajauria, G. Exploring ultrasound, microwave and ultrasound-microwave assisted extraction technologies to increase the extraction of bioactive compounds and antioxidants from brown macroalgae. Mar. Drugs 2020, 18, 172. [CrossRef]

173. Simsek, M.; Sumnu, G.; Sahin, S. Microwave Assisted Extraction of Phenolic Compounds from Sour Cherry Pomace. Sep. Sci. Technol. 2012, 47, 1248-1254. [CrossRef]

174. Zhang, H.F.; Yang, X.H.; Wang, Y. Microwave assisted extraction of secondary metabolites from plants: Current status and future directions. Trends Food Sci. Technol. 2011, 22, 672-688. [CrossRef] 
175. Mirzadeh, M.; Arianejad, M.R.; Khedmat, L. Antioxidant, antiradical, and antimicrobial activities of polysaccharides obtained by microwave-assisted extraction method: A review. Carbohydr. Polym. 2020, 229, 115421. [CrossRef]

176. Boulho, R.; Marty, C.; Freile-Pelegrín, Y.; Robledo, D.; Bourgougnon, N.; Bedoux, G. Antiherpetic (HSV-1) activity of carrageenans from the red seaweed Solieria chordalis (Rhodophyta, Gigartinales) extracted by microwave-assisted extraction (MAE). J. Appl. Phycol. 2017, 29, 2219-2228. [CrossRef]

177. Ren, B.; Chen, C.; Li, C.; Fu, X.; You, L.; Liu, R.H. Optimization of microwave-assisted extraction of Sargassum thunbergii polysaccharides and its antioxidant and hypoglycemic activities. Carbohydr. Polym. 2017, 173, 192-201. [CrossRef]

178. Cao, C.; Huang, Q.; Zhang, B.; Li, C.; Fu, X. Physicochemical characterization and in vitro hypoglycemic activities of polysaccharides from Sargassum pallidum by microwave-assisted aqueous two-phase extraction. Int. J. Biol. Macromol. 2018, 109, 357-368. [CrossRef]

179. Chen, Y.Y.; Xue, Y.T. Optimization of microwave assisted extraction, chemical characterization and antitumor activities of polysaccharides from porphyra haitanensis. Carbohydr. Polym. 2019, 206, 179-186. [CrossRef]

180. He, J.; Xu, Y.; Chen, H.; Sun, P. Extraction, structural characterization, and potential antioxidant activity of the polysaccharides from four seaweeds. Int. J. Mol. Sci. 2016, 17. [CrossRef]

181. Le, B.; Golokhvast, K.S.; Yang, S.H.; Sun, S. Optimization of microwave-assisted extraction of polysaccharides from ulva pertusa and evaluation of their antioxidant activity. Antioxidants 2019, 8. [CrossRef] [PubMed]

182. Tsubaki, S.; Oono, K.; Hiraoka, M.; Onda, A.; Mitani, T. Microwave-assisted hydrothermal extraction of sulfated polysaccharides from Ulva spp. and Monostroma latissimum. Food Chem. 2016, 210, 311-316. [CrossRef] [PubMed]

183. Safari, P.; Rezaei, M.; Shaviklo, A.R. The optimum conditions for the extraction of antioxidant compounds from the Persian gulf green algae (Chaetomorpha sp.) using response surface methodology. J. Food Sci. Technol. 2015, 52, 2974-2981. [CrossRef] [PubMed]

184. López-Hortas, L.; Gannon, L.; Moreira, R.; Chenlo, F.; Domínguez, H.; Torres, M.D. Microwave hydrodiffusion and gravity (MHG) processing of Laminaria ochroleuca brown seaweed. J. Clean. Prod. 2018, 197, 1108-1116. [CrossRef]

185. Zhang, R.; Yuen, A.K.L.; Magnusson, M.; Wright, J.T.; de Nys, R.; Masters, A.F.; Maschmeyer, T. A comparative assessment of the activity and structure of phlorotannins from the brown seaweed Carpophyllum flexuosum. Algal Res. 2018, 29, 130-141. [CrossRef]

186. Abdelhamid, A.; Lajili, S.; Elkaibi, M.A.; Ben Salem, Y.; Abdelhamid, A.; Muller, C.D.; Majdoub, H.; Kraiem, J.; Bouraoui, A. Optimized Extraction, Preliminary Characterization and Evaluation of the in Vitro Anticancer Activity of Phlorotannin-Rich Fraction from the Brown Seaweed, Cystoseira sedoides. J. Aquat. Food Prod. Technol. 2019, 28, 892-909. [CrossRef]

187. Xiao, X.; Si, X.; Yuan, Z.; Xu, X.; Li, G. Isolation of fucoxanthin from edible brown algae by microwave-assisted extraction coupled with high-speed countercurrent chromatography. J. Sep. Sci. 2012, 35, 2313-2317. [CrossRef]

188. Rodriguez-Jasso, R.M.; Mussatto, S.I.; Pastrana, L.; Aguilar, C.N.; Teixeira, J.A. Microwave-assisted extraction of sulfated polysaccharides (fucoidan) from brown seaweed. Carbohydr. Polym. 2011, 86, 1137-1144. [CrossRef]

189. Lorbeer, A.J.; Lahnstein, J.; Fincher, G.B.; Su, P.; Zhang, W. Kinetics of conventional and microwave-assisted fucoidan extractions from the brown alga, Ecklonia radiata. J. Appl. Phycol. 2015, 27, 2079-2087. [CrossRef]

190. Zhong-rui Li Influence of preparation methods on the yield, components and antioxidant activities of polysaccharides from Palmaria palmata. African J. Pharm. Pharmacol. 2012, 6, 1157-1165. [CrossRef]

191. Fabrowska, J.; Messyasz, B.; Szyling, J.; Walkowiak, J.; Łęska, B. Isolation of chlorophylls and carotenoids from freshwater algae using different extraction methods. Phycol. Res. 2018, 66, 52-57. [CrossRef]

192. Puri, M.; Sharma, D.; Barrow, C.J. Enzyme-assisted extraction of bioactives from plants. Trends Biotechnol. 2012, 30, 37-44. [CrossRef] [PubMed]

193. Alam, M.A.; Sarker, M.Z.I.; Ghafoor, K.; Happy, R.A.; Ferdosh, S. Bioactive Compounds and Extraction Techniques. In Recovering Bioactive Compounds from Agricultural Wastes; Nguyen, V.T., Ed.; John Wiley \& Sons Ltd.: Hoboken, NJ, USA, 2017; pp. 33-53.

194. Casas, M.P.; Conde, E.; Domínguez, H.; Moure, A. Ecofriendly extraction of bioactive fractions from Sargassum muticum. Process Biochem. 2019, 79, 166-173. [CrossRef] 
195. Rodrigues, D.; Sousa, S.; Silva, A.; Amorim, M.; Pereira, L.; Rocha-Santos, T.A.P.; Gomes, A.M.P.; Duarte, A.C.; Freitas, A.C. Impact of enzyme- and ultrasound-assisted extraction methods on biological properties of red, brown, and green seaweeds from the Central West Coast of Portugal. J. Agric. Food Chem. 2015, 63, 3177-3188. [CrossRef] [PubMed]

196. Herrero, M.; Sánchez-Camargo, A.d.P.; Cifuentes, A.; Ibáñez, E. Plants, seaweeds, microalgae and food by-products as natural sources of functional ingredients obtained using pressurized liquid extraction and supercritical fluid extraction. TrAC Trends Anal. Chem. 2015, 71, 26-38. [CrossRef]

197. Harrysson, H.; Hayes, M.; Eimer, F.; Carlsson, N.G.; Toth, G.B.; Undeland, I. Production of protein extracts from Swedish red, green, and brown seaweeds, Porphyra umbilicalis Kützing, Ulva lactuca Linnaeus, and Saccharina latissima (Linnaeus) J. V. Lamouroux using three different methods. J. Appl. Phycol. 2018, 30, 3565-3580. [CrossRef]

198. Sun, H.; Ge, X.; Lv, Y.; Wang, A. Application of accelerated solvent extraction in the analysis of organic contaminants, bioactive and nutritional compounds in food and feed. J. Chromatogr. A 2012, 1237, 1-23. [CrossRef]

199. Tierney, M.S.; Smyth, T.J.; Hayes, M.; Soler-Vila, A.; Croft, A.K.; Brunton, N. Influence of pressurised liquid extraction and solid-liquid extraction methods on the phenolic content and antioxidant activities of Irish macroalgae. Int. J. Food Sci. Technol. 2013, 48, 860-869. [CrossRef]

200. Fayad, S.; Nehmé, R.; Tannoury, M.; Lesellier, E.; Pichon, C.; Morin, P. Macroalga Padina pavonica water extracts obtained by pressurized liquid extraction and microwave-assisted extraction inhibit hyaluronidase activity as shown by capillary electrophoresis. J. Chromatogr. A 2017, 1497, 19-27. [CrossRef]

201. Montero, L.; Sánchez-Camargo, A.P.; García-Cañas, V.; Tanniou, A.; Stiger-Pouvreau, V.; Russo, M.; Rastrelli, L.; Cifuentes, A.; Herrero, M.; Ibáñez, E. Anti-proliferative activity and chemical characterization by comprehensive two-dimensional liquid chromatography coupled to mass spectrometry of phlorotannins from the brown macroalga Sargassum muticum collected on North-Atlantic coasts. J. Chromatogr. A 2016, 1428, 115-125. [CrossRef] [PubMed]

202. Anaëlle, T.; Serrano Leon, E.; Laurent, V.; Elena, I.; Mendiola, J.A.; Stéphane, C.; Nelly, K.; Stéphane, L.B.; Luc, M.; Valérie, S.P. Green improved processes to extract bioactive phenolic compounds from brown macroalgae using Sargassum muticum as model. Talanta 2013, 104, 44-52. [CrossRef] [PubMed]

203. Carullo, D.; Abera, B.D.; Casazza, A.A.; Donsì, F.; Perego, P.; Ferrari, G.; Pataro, G. Effect of pulsed electric fields and high pressure homogenization on the aqueous extraction of intracellular compounds from the microalgae Chlorella vulgaris. Algal Res. 2018, 31, 60-69. [CrossRef]

204. La, H.J.; Choi, G.G.; Cho, C.; Seo, S.H.; Srivastava, A.; Jo, B.H.; Lee, J.Y.; Jin, Y.S.; Oh, H.M. Increased lipid productivity of Acutodesmus dimorphus using optimized pulsed electric field. J. Appl. Phycol. 2016, 28, 931-938. [CrossRef]

205. Polikovsky, M.; Fernand, F.; Sack, M.; Frey, W.; Müller, G.; Golberg, A. Towards marine biorefineries: Selective proteins extractions from marine macroalgae Ulva with pulsed electric fields. Innov. Food Sci. Emerg. Technol. 2016, 37, 194-200. [CrossRef]

206. Gupta, S.; Abu-Ghannam, N. Recent developments in the application of seaweeds or seaweed extracts as a means for enhancing the safety and quality attributes of foods. Innov. Food Sci. Emerg. Technol. 2011, 12, 600-609. [CrossRef]

207. Sofi, S.A.; Singh, J.; Rafiq, S.; Ashraf, U.; Dar, B.N.; Nayik, G.A. A Comprehensive Review on Antimicrobial Packaging and its Use in Food Packaging. Curr. Nutr. Food Sci. 2018, 14, 305-312. [CrossRef]

208. Poveda-castillo, G.C.; Rodrigo, D.; Mart, A.; Consuelo, M. Bioactivity of Fucoidan as an Antimicrobial Agent in a New Functional Beverage. Beverages 2018, 4, 64. [CrossRef]

209. Øverland, M.; Mydland, L.T.; Skrede, A. Marine macroalgae as a source of protein and bioactive compounds in feed for monogastric animals. J. Sci. Food Agric. 2019, 99, 13-24. [CrossRef]

210. Mohan, K.; Ravichandran, S.; Muralisankar, T.; Uthayakumar, V.; Chandirasekar, R.; Seedevi, P.; Abirami, R.G.; Rajan, D.K. Application of marine-derived polysaccharides as immunostimulants in aquaculture: A review of current knowledge and further perspectives. Fish Shellfish Immunol. 2019, 86, 1177-1193. [CrossRef]

211. Madhiyazhagan, P.; Murugan, K.; Kumar, A.N.; Nataraj, T.; Dinesh, D.; Panneerselvam, C.; Subramaniam, J.; Kumar, P.M.; Suresh, U.; Roni, M.; et al. Sargassum muticum synthesized silver nanoparticles: An effective control tool against mosquito vectors and bacterial pathogens. Parasitol. Res. 2015, 114, 4305-4317. [CrossRef] 
212. Pugazhendhi, A.; Prabakar, D.; Jacob, J.M.; Karuppusamy, I.; Saratale, R.G. Synthesis and characterization of silver nanoparticles using Gelidium amansii and its antimicrobial property against various pathogenic bacteria. Microb. Pathog. 2018, 114, 41-45. [CrossRef] [PubMed]

213. Kumar, P.; Senthamil Selvi, S.; Govindaraju, M. Seaweed-mediated biosynthesis of silver nanoparticles using Gracilaria corticata for its antifungal activity against Candida spp. Appl. Nanosci. 2013, 3, 495-500. [CrossRef]

214. de Aragão, A.P.; de Oliveira, T.M.; Quelemes, P.V.; Perfeito, M.L.G.; Araújo, M.C.; Santiago, J.d.A.S.; Cardoso, V.S.; Quaresma, P.; de Souza de Almeida Leite, J.R.; da Silva, D.A. Green synthesis of silver nanoparticles using the seaweed Gracilaria birdiae and their antibacterial activity. Arab. J. Chem. 2019, 12, 4182-4188. [CrossRef]

215. Selvaraj, P.; Neethu, E.; Rathika, P.; Jayaseeli, J.P.R.; Jermy, B.R.; AbdulAzeez, S.; Borgio, J.F.; Dhas, T.S. Antibacterial potentials of methanolic extract and silver nanoparticles from marine algae. Biocatal. Agric. Biotechnol. 2020, 28, 101719. [CrossRef]

216. Fatima, R.; Priya, M.; Indurthi, L.; Radhakrishnan, V.; Sudhakaran, R. Biosynthesis of silver nanoparticles using red algae Portieria hornemannii and its antibacterial activity against fish pathogens. Microb. Pathog. 2020, 138, 103780. [CrossRef] [PubMed]

217. El-Rafie, H.M.; El-Rafie, M.H.; Zahran, M.K. Green synthesis of silver nanoparticles using polysaccharides extracted from marine macro algae. Carbohydr. Polym. 2013, 96, 403-410. [CrossRef]

218. Stalin Dhas, T.; Ganesh Kumar, V.; Karthick, V.; Jini Angel, K.; Govindaraju, K. Facile synthesis of silver chloride nanoparticles using marine alga and its antibacterial efficacy. Spectrochim. Acta Part A Mol. Biomol. Spectrosc. 2014, 120, 416-420. [CrossRef]

219. Arockiya Aarthi Rajathi, F.; Parthiban, C.; Ganesh Kumar, V.; Anantharaman, P. Biosynthesis of antibacterial gold nanoparticles using brown alga, Stoechospermum marginatum (kützing). Spectrochim. Acta Part A Mol. Biomol. Spectrosc. 2012, 99, 166-173. [CrossRef]

220. Dhas, T.S.; Sowmiya, P.; Kumar, V.G.; Ravi, M.; Suthindhiran, K.; Borgio, J.F.; Narendrakumar, G.; Kumar, V.R.; Karthick, V.; Kumar, C.M.V. Antimicrobial effect of Sargassum plagiophyllum mediated gold nanoparticles on Escherichia coli and Salmonella typhi. Biocatal. Agric. Biotechnol. 2020, 26, 101627. [CrossRef]

221. Salem, D.M.S.A.; Ismail, M.M.; Aly-Eldeen, M.A. Biogenic synthesis and antimicrobial potency of iron oxide (Fe3O4) nanoparticles using algae harvested from the Mediterranean Sea, Egypt. Egypt. J. Aquat. Res. 2019, 45, 197-204. [CrossRef]

222. Mashjoor, S.; Yousefzadi, M.; Zolgharnain, H.; Kamrani, E.; Alishahi, M. Organic and inorganic nano-Fe3O4: Alga Ulva flexuosa-based synthesis, antimicrobial effects and acute toxicity to briny water rotifer Brachionus rotundiformis. Environ. Pollut. 2018, 237, 50-64. [CrossRef] [PubMed]

223. Kumaresan, M.; Vijai Anand, K.; Govindaraju, K.; Tamilselvan, S.; Ganesh Kumar, V. Seaweed Sargassum wightii mediated preparation of zirconia $(\mathrm{ZrO} 2)$ nanoparticles and their antibacterial activity against gram positive and gram negative bacteria. Microb. Pathog. 2018, 124, 311-315. [CrossRef] [PubMed]

224. Pugazhendhi, A.; Prabhu, R.; Muruganantham, K.; Shanmuganathan, R.; Natarajan, S. Anticancer, antimicrobial and photocatalytic activities of green synthesized magnesium oxide nanoparticles (MgONPs) using aqueous extract of Sargassum wightii. J. Photochem. Photobiol. B Biol. 2019, 190, 86-97. [CrossRef]

225. Nagarajan, S.; Arumugam Kuppusamy, K. Extracellular synthesis of zinc oxide nanoparticle using seaweeds of gulf of Mannar, India. J. Nanobiotechnol. 2013, 11, 1-11. [CrossRef]

226. Dang, H.; Lovell, C.R. Microbial Surface Colonization and Biofilm Development in Marine Environments. Microbiol. Mol. Biol. Rev. 2016, 80, 91-138. [CrossRef]

227. Batista, D.; Carvalho, A.P.; Costa, R.; Coutinho, R.; Dobretsov, S. Extracts of macroalgae from the Brazilian coast inhibit bacterial quorum sensing. Bot. Mar. 2014, 57, 441-447. [CrossRef]

228. Ying-ying, S.; Hui, W.; Gan-lin, G.; Yin-fang, P. Green alga Ulva pertusa - a new source of bioactive compounds with antialgal activity. Environ. Sci. Pollut. Res. 2015, 22, 10351-10359. [CrossRef]

229. Nakajima, N.; Sugimoto, N.; Ohki, K.; Kamiya, M. Diversity of phlorotannin profiles among sargassasacean species affecting variation and abundance of epiphytes. Eur. J. Phycol. 2016, 51, 307-316. [CrossRef]

230. Dahms, H.U.; Dobretsov, S. Antifouling Compounds from Marine Macroalgae. Mar. Drugs 2017, 15, 265. [CrossRef]

231. Carvalho, A.P.; Batista, D.; Dobretsov, S.; Coutinho, R. Extracts of seaweeds as potential inhibitors of quorum sensing and bacterial growth. J. Appl. Phycol. 2017, 29, 789-797. [CrossRef] 
232. Sethupathy, S.; Shanmuganathan, B.; Kasi, P.D.; Karutha Pandian, S. Alpha-bisabolol from brown macroalga Padina gymnospora mitigates biofilm formation and quorum sensing controlled virulence factor production in Serratia marcescens. J. Appl. Phycol. 2016, 28, 1987-1996. [CrossRef]

233. Du, Y.; Sun, J.; Gong, Q.; Wang, Y.; Fu, P.; Zhu, W. New $\alpha$-Pyridones with Quorum-Sensing Inhibitory Activity from Diversity-Enhanced Extracts of a Streptomyces sp. Derived from Marine Algae. J. Agric. Food Chem. 2018, 66, 1807-1812. [CrossRef] [PubMed]

234. Daglia, M. Polyphenols as antimicrobial agents. Curr. Opin. Biotechnol. 2012, 23, 174-181. [CrossRef] [PubMed]

235. Khanna, P.; Kaur, A.; Goyal, D. Algae-based metallic nanoparticles: Synthesis, characterization and applications. J. Microbiol. Methods 2019, 163, 105656. [CrossRef] [PubMed]

236. Sri, V.; Prakash, S.; Ramasubburayan, R. Enzyme and Microbial Technology Seaweeds: A resource for marine bionanotechnology. Enzyme Microb. Technol. 2016, 95, 45-57. [CrossRef]

237. Sudhakar, M.S.; Aggarwal, A.; Sah, M.K. Engineering biomaterials for the bioremediation: Advances in nanotechnological approaches for heavy metals removal from natural resources. In Emerging Technologies in Environmental Bioremediation; Elsevier Inc.: Amsterdam, The Netherlands, 2020; pp. 323-340, ISBN 9780128198605.

238. Gómez-Ordóñez, E.; Jiménez-Escrig, A.; Rupérez, P. Dietary fibre and physicochemical properties of several edible seaweeds from the northwestern Spanish coast. Food Res. Int. 2010, 43, 2289-2294. [CrossRef]

239. Olszewska, M.A.; Gędas, A.; Simões, M. Antimicrobial polyphenol-rich extracts: Applications and limitations in the food industry. Food Res. Int. 2020, 134, 109214. [CrossRef]

240. Lourenço-Lopes, C.; Garcia-Oliveira, P.; Carpena, M.; Fraga-Corral, M.; Jimenez-Lopez, C.; Pereira, A.G.; Prieto, M.A.; Simal-Gándara, J. Scientific Approaches on Extraction, Purification and Stability for the Commercialization of Fucoxanthin Recovered from Brown Algae. Foods 2020, 9, 1113. [CrossRef]

(C) 2020 by the authors. Licensee MDPI, Basel, Switzerland. This article is an open access article distributed under the terms and conditions of the Creative Commons Attribution (CC BY) license (http://creativecommons.org/licenses/by/4.0/). 